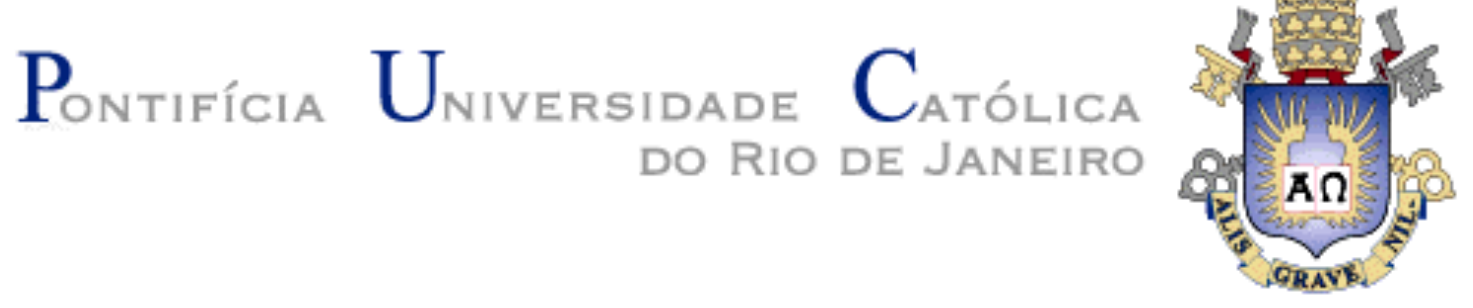

Marcelo Couto Feitosa

\title{
Natureza humana, vida cognitiva e vida afetiva na Ética \\ de Spinoza
}

\section{Dissertação de Mestrado}

Dissertação apresentada como requisito parcial para obtenção do grau de Mestre pelo programa de Pós-Graduação em Filosofia, do Departamento de Filosofia, do Centro de Teologia e Ciências Humanas, da Pontifícia Universidade Católica do Rio de Janeiro - PUC-Rio.

Orientadora: Profa. Déborah Danowski Coorientador: Prof. Rafael Mófreitas Saldanha

Rio de janeiro, março 2021 


\section{Pontifícia Universidade Católica $_{\text {a }}$

\section{Marcelo Couto Feitosa}

Natureza humana, vida cognitiva e vida afetiva na Ética de Spinoza

Dissertação apresentada como requisito parcial para obtenção do grau de Mestre pelo programa de Pós-Graduação em Filosofia, do Departamento de Filosofia, do Centro de Teologia e Ciências Humanas, da Pontifícia Universidade Católica do Rio de Janeiro - PUC-Rio.

Aprovada pela Comissão Examinadora abaixo.

Profa. Déborah Danowski

Orientadora

Departamento de Filosofia - PUC-Rio

Prof. Rafael Mófreitas Saldanha

Coorientador

Departamento de Filosofia - UFRJ

Prof. Ulysses Pinheiro

Departamento de Filosofia - UFRJ

Prof. Alexandre Pinto Mendes

Departamento de Ciências Jurídicas - UFRRJ

Rio de janeiro, 01 de março de 2021 
Todos os direitos reservados. É proibida a reprodução total ou parcial do trabalho sem a autorização da universidade, do autor e do orientadora.

\section{Marcelo Couto Feitosa}

Licenciou-se em Filosofia pela UNIRIO (Universidade Federal do Estado do Rio de Janeiro) em 2017. Apresentou trabalhos em congressos nacionais e internacionais sobre pesquisa em diversas áreas da filosofia de Spinoza. Apresentou trabalhos em congressos nacionais sobre pesquisa teórica em fotografia.

Ficha Catalográfica

Feitosa, Marcelo Couto

Natureza humana, vida cognitiva e vida afetiva na Ética de Spinoza / Marcelo Couto Feitosa ; orientadora: Déborah Danowski ; coorientador: Rafael Mófreitas Saldanha. - 2021.

127 f. ; $30 \mathrm{~cm}$

Dissertação (mestrado)-Pontifícia Universidade Católica do Rio de Janeiro, Departamento de Filosofia, 2021.

Inclui bibliografia 
Para minha mãe, Jael, meus irmãos e minha esposa, Andrea. Acreditar sempre foi algo que aprendi com vocês. 


\section{Agradecimentos}

"O presente trabalho foi realizado com apoio da Coordenação de Aperfeiçoamento de Pessoal de nível superior - Brasil (CAPES) - Código de financiamento 001.”

À minha orientadora professora Déborah Danowski pelo apoio, acolhimento e por ter acreditado nesta pesquisa.

Ao meu coorientador professor Rafael Saldanha pela contribuição e parceria que tantas vezes foram determinantes para a realização deste trabalho.

Ao CNPq e à PUC-Rio pelos auxílios concedidos, sem os quais este trabalho não poderia ter sido realizado.

À minha esposa pelo incentivo, parceria, compreensão e consolo nas horas mais difíceis.

À minha mãe e aos meus irmãos pelos anos de abrigo, convivência e carinho.

Aos meus familiares Marilis Vizzotto, Roberto Lopes e Roberta Lopes pelo apoio incondicional.

Aos amigos incentivadores de todas as horas: Lupa, Evelen Gouvêa, Fabiana Maia, Eduardo Weiss, Carlos Eduardo, Vitor d'Ávila, Rodrigo Braga, Karinete, Gabriel e tantos outros.

Aos meus queridos colegas dos grupos de estudo "Amigos da Unirio" e "Spinoza e nós" pela torcida, incentivo e colaboração.

Aos professores Ericka Itokazu, Maxime Rovere e Baptiste Noel pela enorme contribuição nos estudos sobre Spinoza.

Aos meus colegas da PUC-Rio.

A todos os professores e funcionários do departamento de Filosofia da PUC-Rio pelo convívio e aprendizado.

Aos professores que aceitaram participar da banca examinadora. 


\section{Resumo}

Feitosa, Marcelo Couto; Danowski, Déborah; Saldanha, Rafael. Natureza humana, vida cognitiva e vida afetiva na Ética de Spinoza. Rio de Janeiro, 2021. 127p. Dissertação de Mestrado - Departamento de Filosofia, Pontifícia Universidade Católica do Rio de Janeiro.

Esta dissertação tem como tema um estudo da natureza humana, da vida cognitiva e da vida afetiva tais como são demonstradas por Spinoza, na segunda e terceira partes de sua obra magna, a Ética. Para alcançar tal objetivo, optamos por fazer uma leitura minuciosa da obra, seguindo sua investigação a partir das ideias tais como são demonstradas pelo próprio Spinoza, assim como na ordem em que são apresentadas. Uma das grandes inovações da Ética é o seu modelo de natureza humana que não se separa da natureza divina e o impacto que isso representa para o processo de formação das coisas singulares em sua filosofia. $\mathrm{Na}$ primeira parte da dissertação, apresentamos a dedução pela qual Spinoza estabelece a mente humana como aquilo que deve se seguir dos atributos pensamento e extensão, cuja natureza é responsável pela origem dos modos singulares, entre os quais o modo humano de existência. Na segunda parte, demonstramos como a doutrina da substância única é determinante para a inovadora concepção de corpo unido à mente, que produz efeitos imediatos nos gêneros de conhecimento do método spinozista. Na terceira e última parte, apresentamos uma investigação sobre a ciência spinozista dos afetos, examinando cada etapa de sua demonstração, na Parte III da Ética. Ao fim da dissertação, indicamos que a demonstração spinozista evidencia que a natureza humana é resultado de uma realidade que une vida cognitiva e vida afetiva.

\section{Palavras-chave}

Ética; mente; corpo; afetos; Spinoza. 


\section{Abstract}

Feitosa, Marcelo Couto; Danowski, Déborah (Advisor); Saldanha, Rafael (Advisor). Human nature, cognitive life and affective life in Spinoza's Ethics. Rio de Janeiro, 2021. 127p. Dissertação de Mestrado Departamento de Filosofia, Pontifícia Universidade Católica do Rio de Janeiro.

The present dissertation has as its theme a study of human nature, cognitive life and affective life in the way they were demonstrated by Spinoza in the second and third parts of his masterpiece, the Ethics. In order to achieve this goal we chose to carry out a thorough reading of this work, following his investigation of ideas as demonstrated by Spinoza himself and in the order they were presented by him. One of the great innovations of Ethics is its model of human nature that can not be separated from the divine nature as well as the impact that it represents for the process of formation of the singular modes in his philosophy. In the first part of this dissertation, we present the deductive process through which Spinoza establishes the human mind as something that must follow from thought and extension attributes, whose nature is responsible for the origin of singular modes, among them the human mode of existence. In the second part, we demonstrate how the doctrine of the unique substance is decisive for Spinoza's innovative conception of the mind-body union as well as the immediate effects it produces at the spinozist method's genders of knowledge. In the third and last part, we present an investigation on Spinoza's science of affects, closely examining each step of its demonstration within the Part III of the Ethics. After the presentation of these three stages of development of Spinoza's philosophy we intend to show that the author's demonstrations points that human nature is the result of a reality that unites cognitive life and affective life.

\section{Keywords}

Ethics; mind; body; affections; Spinoza. 


\section{Sumário}

1. Introdução

10

2. A Parte II da Ética e o que deve seguir necessariamente da essência de Deus: a natureza humana

2.1. Sobre a estrutura da Parte II: uma breve descrição

2.1.2. As definições da Parte II e a essência da mente

2.1.3. Os axiomas da Parte II e as propriedades universais da mente

2.2. As proposições iniciais da Parte II e a mente como expressão dos atributos pensamento e extensão

2.2.1. A mesma ordem e a mesma conexão das ideias e das coisas e o conhecimento dos modos singulares

2.2.2. O ser formal das coisas singulares e a origem do modo humano

3. O objeto da ideia que constitui a mente humana: o corpo

3.1. A natureza dos corpos em geral

3.1.1. A primeira parte da pequena física e a natureza dos corpos simples

3.1.2. A segunda parte da pequena física e os corpos compostos 
3.2.1. Breves considerações sobre a união da mente com o corpo na segunda parte da Ética

3.3. As ideias das afecções do corpo e a imaginação como conhecimento do primeiro gênero

3.3.1. A mente internamente determinada ao múltiplo e simultâneo e os conhecimentos de segundo e terceiro gênero

3.3.2. A dedução do conhecimento de segundo gênero e as noções comuns

3.3.3. A dedução do conhecimento de terceiro gênero e a ciência intuitiva

3.4. Escólio da proposição 49: as considerações finais da segunda parte da Ética e os ensinamentos da doutrina para uso da vida

4. Origem e natureza dos afetos e a vida afetiva na Parte III da Ética

4.1. Sobre a estrutura da Parte III: uma breve descrição

4.2. Para àqueles que preferem amaldiçoar ou ridicularizar os afetos e ações humanas em vez de entendê-los: Spinoza e os fundamentos da vida afetiva

4.3. A mais singular expressão da potência: o conatus

4.4. Desejo, alegria e tristeza: a tríade spinozista dos afetos primários

4.5. A ciência dos afetos

5. Conclusão 


\title{
1 \\ Introdução
}

\begin{abstract}
Meu caro Spinoza,
Você é mesmo singular. Através dos séculos continua despertando admirações fervorosas, oposições, leituras diferentes de seus livros, não só no mundo dos filósofos, mas, curiosamente, atraindo pensadores das mais diversas áreas do saber, até despretensiosos leitores que insistem, embora sem formação filosófica (e este é o meu caso), no difícil e fascinante estudo da filosofia. ${ }^{1}$
\end{abstract}

Nise da Silveira

A frase escolhida pela médica psiquiatra brasileira Nise da Silveira para dar início à sua obra Cartas a Spinoza - "você é mesmo singular" - não poderia ser melhor exemplo para explicar, não apenas a razão do seu fascínio pela filosofia de Spinoza, como o de muitos outros que, desde as primeiras publicações da obra spinozista, ainda no longínquo século XVII, não cessam de manifestar seu encantamento mediante as descobertas de uma filosofia tão original.

A própria Nise da Silveira, na continuação da sua carta, destaca alguns nomes de personalidades das mais diversas áreas do conhecimento que, ao longo dos anos, de alguma maneira fizeram questão de expressar o fascínio que sentiam pela filosofia de Spinoza. A autora chega a mencionar que "mais surpreendente ainda é que, à atração intelectual, muitas vezes venham juntar-se sentimentos profundos de afeição." ${ }^{2}$ Nise da Silveira se refere a nomes como Einstein, que afirmava constantemente acreditar no Deus de Spinoza; o poeta francês do século XIX, Sully Prudhomme, que dedicou a Spinoza o soneto $U n$ Bonhomme (Um homem bom); o escritor brasileiro Machado de Assis, que, em 1880, homenageou o filósofo com o soneto Spinoza; o escritor e grande erudito alemão Goethe, que segundo Nise "permaneceu em reclusão durante meses para estudar a Ética e, a partir daí, passou por um processo de transformação."3 Além disso, ainda podemos mencionar a escritora Clarice Lispector, cujo primeiro romance, Perto do coração selvagem, possui forte influência da sua leitura pessoal da Ética, e também o poeta argentino Jorge Luis Borges, que na obra $E l$ outro, el mismo, rende sua homenagem no soneto Spinoza. Tantos nomes

\footnotetext{
${ }^{1}$ SILVEIRA, N. da. Cartas a Spinoza, p. 19.

${ }^{2}$ Ibid., p. 19.

${ }^{3}$ Ibid., p. 22.
} 
levaram Nise da Silveira a argumentar, em sua carta, não saber "de filósofo algum a quem tenham sido dedicadas poesias ou comovidas evocações de encontros decisivos."4

Certamente que, além dos poetas e escritores, há também os eruditos. Esses são muitos e dizem respeito a um grande contingente de estudiosos e comentadores da filosofia spinozista, assim como também de numerosos filósofos que, ao longo da história do pensamento ocidental, da mesma maneira que os poetas e os escritores, também expressaram admiração ao comentaram o pensamento de Spinoza através de cartas e outros documentos. Entre esses, podemos destacar o filósofo francês Étienne Vacherot e sua afirmação de que Spinoza "é o maior dialético que já apareceu em metafísica"; o pensador alemão Ludwig Noiré e sua observação de que Spinoza "é o maior espírito filosófico desde Aristóteles"; o filósofo e teólogo Friedrich Schleiermacher, que se referiu a Spinoza como santo: "rendei comigo homenagem aos manes do santo Spinoza"5; o grande expoente do idealismo alemão, Schelling, que numa das cartas da célebre correspondência com Hegel, em 1795, declarou: "Tornei-me entretanto spinozista! Não te surpreenda.”; o próprio Hegel que, no terceiro volume de suas Lições de história da filosofia, conclui que "ou se é um 'spinozista' ou não se é filósofo de forma alguma”; e, por fim, Nietzsche e seu entusiasmo na famosa carta a Franz Overbeck, na qual afirmou estar "totalmente estupefato, maravilhado! Tenho um precursor, e que precursor! Eu não conhecia quase nada de Spinoza: que agora eu seja impelido a ele, foi um 'ato instintivo'."6

A iniciativa de apresentar esse breve resumo sobre a recepção positiva com que a filosofia de Spinoza foi demonstrada pelos poetas, escritores e eruditos descritos acima, encontra sua justificativa no simples fato de que o

\footnotetext{
${ }^{4}$ SILVEIRA, N. da. Cartas a Spinoza, p. 22.

${ }^{5}$ Em se tratando de um filósofo-teólogo de início do século XIX, o elogio feito a Spinoza por Schleiermacher, normalmente seria considerado algo inusitado. Contudo, como explica o historiador da filosofia Giovanni Reale, "a religião para Schleiermacher é uma relação do homem com a totalidade, é intuição e sentimento do infinito. A religião aspira a intuir o universo, tende a ver no homem e em todas as outras coisas finitas, o infinito, a imagem, a marca, a expressão do infinito: a ação do infinito sobre o homem é, portanto, a intuição, e a resposta do sujeito é o sentimento de total dependência do infinito." Ou seja, trata-se de uma concepção romântica de religião que é muito próxima à doutrina spinozista. REALE, G. História da filosofia 5: do romantismo ao empiriocriticismo, p. 20.

${ }^{6}$ Carta de Nietzshe a Overbecck. MARTINS, A. (Org.). O mais potente dos afetos: Spinoza \& Nietzsche, p. 2.
} 
estudo que será desenvolvido a seguir também é fruto desse mesmo entusiasmo. Sendo assim, é preciso esclarecer que a pesquisa que aqui será apresentada não irá propor nada além do que o retorno a alguns temas considerados clássicos da Ética, temas, aliás, que, ao longo de décadas, vêm sendo motivo de intensos debates sobre o pensamento de Spinoza, o que tem contribuindo imensamente para o desenvolvimento dos estudos acerca de sua filosofia. Contudo, como bem destacou Nise da Silveira em sua primeira carta, Spinoza é um filósofo "singular", que desperta "oposições" e "leituras diferentes de seus livros". Certamente, tais características não são uma exclusividade de Spinoza, muito pelo contrário. Trata-se de algo que facilmente se observa em grande parte dos estudos filosóficos, independente de autor, da filosofia ou do tema em questão. Porém, em Spinoza, a distinção de interpretações que observamos nos resultados apresentados por muitos estudos que comentam sua filosofia são a tal ponto divergentes entre si, que mais parecem se referir a autores diferentes. Nesse sentido, aqui cabe destacar uma importante observação feita por Vidal Peña na introdução de sua tradução da Ética, nos lembrando que para

Deleuze, o mérito fundamental do trabalho de Gueroult sobre Espinosa consistia em seguir a ordem das razões, em não interpretar, mas ler. 'Compreender a Ética' significaria entender como é coerente, 'associando-se ao processo demonstrativo' de Espinosa, como diz Gueroult. Não se trata de interpretar - a interpretação falsifica -, mas de entender literalmente que Espinosa disse o que queria dizer e na ordem em que queria dizer. A única introdução possível à Ética seria, de algum modo, um convite à sua leitura cuidadosa. ${ }^{7}$

Eis porque, então, surge a razão pela qual o estudo que será apresentado a seguir terá como uma de suas principais metas a iniciativa de investigar as questões relativas ao seu recorte temático específico, isto é, natureza humana, vida cognitiva e vida afetiva na Ética de Spinoza, a partir de uma "leitura cuidadosa da Ética". Trata-se de um esforço para tentar entender como essas questões são demonstradas pelo próprio Spinoza, em sua obra. Há uma série de

\footnotetext{
7 "Para Deleuze, el mérito fundamental de la obra de Gueroult sobre Espinosa ha consistido en ceñirse al ordre des raisons, en no interpretar, sino leer. 'Comprender la Ética' significaría comprender cómo es coherente, 'asociarse al proceso demostrativo' de Espinosa, como Gueroult dice. No se trata de interpretar - la interpretación falsea - sino de comprender literalmente que Espinosa ha dicho lo que quería decir y en el orden en que quería decirlo. La única introducción posible a la Ética sería, de algún modo, una invitación a su lectura atenta." ESPINOZA, B. Ética: demostrada según el orden geométrico, Introdução, p. 17.
} 
implicações e desafios a serem enfrentados por uma iniciativa como esta. O maior deles, no entanto, talvez seja a necessidade de se fazer uma investigação respeitando os critérios que uma demonstração em ordem geométrica exige, bem como respeitando, também, o rigor do método dedutível com que a doutrina spinozista expõe suas ideias. Todavia, ainda que a própria Ética seja a principal referência que será utilizada no decorrer de nossa pesquisa, esse estudo reconhece que não há possibilidade de alcançar seus objetivos a partir apenas de seu próprio "entendimento" sobre a obra spinozista, sem a contribuição do entendimento de outras obras que são reconhecidamente de extrema importância para o estudo da filosofia de Spinoza. Portanto, em momento algum, deixaremos de fazer uso da vasta produção acadêmica de grandes comentadores da obra de Spinoza, tais como Martial Gueroult, Marilena Chaui, Gilles Deleuze e tantos outros.

Uma vez esclarecido o perfil metodológico que será adotado pela pesquisa, resta apenas explicar que o estudo que apresentaremos a seguir sobre natureza humana, vida cognitiva e vida afetiva na Ética de Spinoza, encontra-se dividido em três capítulos. No primeiro, cujo título é a Parte II da Ética e o que deve seguir necessariamente da essência de Deus: a natureza humana, será abordado o início do processo dedutivo que marca a passagem da natureza naturante para a natureza naturada, isto é, a transição entre a demonstração da natureza de Deus e a natureza "do que deve seguir necessariamente de sua essência”, isto é, as coisas singulares. Veremos que Spinoza, após ter afirmado no apêndice que conclui a Parte I da Ética - que em seguida irá "tratar da natureza humana", contudo inicia a segunda parte decretando que irá explicar "o que deve seguir necessariamente da essência de Deus", quer dizer, inicia a dedução da natureza humana, assim como de todas as coisas singulares a ela relacionadas, estabelecendo-as como aquilo que segue da causalidade necessária do ente eterno e substância absolutamente infinita, ou seja, Deus. Veremos como Spinoza garante a causalidade necessária que dá origem à natureza humana a partir da dedução de apenas dois atributos da substância: o pensamento e a extensão. Assim como também poderemos observar que a equiparação entre as potências desses dois atributos permitirá a Spinoza deduzir a equivalência entre a ordem e a conexão das ideias e a ordem e a conexão das 
coisas, como causa da origem de todas as coisas singulares, condição necessária e princípio fundamental que permite a dedução do modo humano de existência enquanto união da mente (ordem e conexão das ideias) com seu corpo (ordem e conexão das coisas).

Uma vez esclarecida a ontologia da natureza humana, no segundo capítulo, cujo título é $O$ objeto da ideia que constitui a mente humana: o corpo, o estudo irá investigar o longo percurso no qual Spinoza demonstra as várias etapas da união da mente com seu corpo, a dedução da mente como modo de pensamento e a vida cognitiva. Nesse processo, iremos observar como Spinoza deduz a natureza do corpo humano a partir de uma "pequena física" em que inicialmente o corpo é deduzido por meio de suas propriedades singulares, isto é, daquilo que é próprio do corpo de um único indivíduo, para, em seguida, deduzir suas propriedades compostas, ou seja, aquilo que se refere à união dos corpos de vários indivíduos. Feito isso, veremos que Spinoza, a partir da segunda metade da Parte II, demonstrará como a união da mente com seu corpo terá grande influência na dedução dos três gêneros do conhecimento de sua doutrina. Por fim, no longo escólio que encerra a Parte II - cuja estrutura argumentativa é bastante semelhante ao apêndice que finaliza a Parte I - iremos observar como o próprio Spinoza irá indicar quanto o conhecimento de sua doutrina pode contribuir "para o uso da vida", algo semelhante a uma espécie de "pequena ética dos costumes" com a qual ele conclui a demonstração da vida cognitiva e a segunda parte da Ética.

Por fim, no terceiro e último capítulo, cujo título é Origem e natureza dos afetos e a vida afetiva na parte III da Ética, o estudo irá se dedicar à investigação da dedução spinozista da dinâmica (ou ciência) dos afetos e a vida afetiva. Considerado um dos marcos originais da filosofia de Spinoza, veremos como essa originalidade surge a partir de uma postura radical de Spinoza em substituir o conceito de emotio e passio pelo de affectus. Tal mudança permitiu a Spinoza operar diversas modificações na maneira como o tema era abordado pela tradição filosófica até então. Veremos como Spinoza parte de uma singela distinção entre afecções e afetos para, enfim, chegar a um revolucionário sistema de variação da potência de um modo singular de existência, aquilo que irá determinar sua essência e seu esforço atual de perseverar no próprio ser, isto 
é, veremos como Spinoza projeta, na lógica do conatus, as bases da sua ciência dos afetos. Além disso, também iremos investigar como a ciência spinozista dos afetos, além da lógica do conatus, também se faz valer de uma dinâmica elaborada a partir dos afetos de alegria, tristeza e desejo, chamados por Spinoza de afetos primários, para demonstrar como se constituem todos os outros afetos, assim como a demonstração da influência dos três - por meio das operações da imaginação - na variação da potência de agir dos modos singulares. Depois disso, será destacado por esse estudo que Spinoza apresenta as definições de 59 afetos, concluindo a Parte III da Ética com uma "definição geral dos afetos", que é acompanhada de uma explicação. Nas definições dos 59 afetos, nossa investigação chamará a atenção para a presença, direta ou indiretamente, de um dos três afetos da tríade dos afetos primários (desejo, alegria e tristeza) na formação de todos os outros afetos. Já na "definição geral dos afetos" e sua explicação, daremos atenção especial à afirmação spinozista de que as afecções que modificam a potência de agir do corpo e da mente nos fazem conhecer mais a natureza de nosso próprio corpo, do que a natureza dos corpos externos que nos afetam.

Com isso, o que de fato esse estudo pretende alcançar a partir do planejamento acima apresentado, nada mais é do que chegar ao fim de sua jornada conquistando apenas aquilo que é sua principal meta, isto é, o entendimento sobre como a Ética de Spinoza explica a natureza humana por meio da vida cognitiva e da vida afetiva. Sabemos que isso ainda é pouco para entender a natureza humana, tal como demonstrada na Ética. Um estudo completo sobre o tema exigiria uma pesquisa bem mais ampla, envolvendo todas as partes da obra, afinal a Ética como um todo é uma obra sobre a Natureza, e isso também inclui a natureza humana, que, nesse caso, precisa ser entendida, não como sendo apenas uma parte da Natureza, mas como pertencendo à sua totalidade. Portanto, só nos resta esclarecer, desde já, que o estudo que será apresentado a seguir, por mais que demande muito esforço em seus objetivos, não conseguirá oferecer nada além do que uma parte do conhecimento que Spinoza demonstra sobre a natureza humana em sua obra. Contudo, se apenas isso for conquistado, isso significa que esse estudo terá conseguido alcançar sua principal meta, o que será motivo de grande alegria 
para seu autor, assim como para todos aqueles que, de alguma maneira, contribuíram para a realização desta pesquisa. 


\title{
2 \\ A Parte II da Ética e o que deve seguir necessariamente da essência de Deus: a natureza humana
}

\author{
Da necessidade da natureza divina devem seguir infinitas coisas em infinitos modos (isto \\ é, tudo que pode cair sob o intelecto infinito). ${ }^{8}$
}

Spinoza

No apêndice que finaliza a Parte I da Ética, Spinoza anuncia que na etapa seguinte de sua obra irá abordar questões que ele próprio afirma se tratar "da natureza humana". Isso acontece durante uma argumentação em que Spinoza esclarece que irá investigar os efeitos que os afetos produzem na mente humana, enquanto esta tenta conceber a natureza das coisas a partir das noções que lhe são úteis, tais como: "Louvor, Vitupério, Pecado e Mérito. Explicarei as últimas [afirma Spinoza] mais à frente [referindo-se à Parte IV], depois que me tiver ocupado da natureza humana [referindo-se à Parte II]." ${ }^{9}$ Contudo, no breve texto que inicia a Parte II, Spinoza afirma: "Passo agora a explicar o que deve seguir necessariamente da essência de Deus, ou seja, do Ente eterno e infinito." ${ }^{\prime 10}$ Ora, Spinoza conclui a Parte I anunciando que irá tratar da natureza humana, mas inicia a Parte II afirmando que passará "a explicar o que deve seguir necessariamente da essência de Deus". Estaria Spinoza sugerindo que há uma relação intrínseca e uma associação imediata entre essas duas situações?

Certamente que sim, mas isso não significa que se trata de uma correspondência imediata, muito pelo contrário. Mas há um fato importante que podemos concluir desde já: a de que a natureza humana a que Spinoza se refere no apêndice da Parte I, é a mesma que será deduzida como aquilo que segue necessariamente da essência de Deus. Portanto, ao contrário da ontologia cartesiana, em que a dedução da natureza do espírito humano, isto é, a mente humana, é demonstrada primeiro, na Segunda Meditação, enquanto a dedução daquilo que é causa de sua origem, ou seja, Deus, é demonstrada posteriormente, na Terceira Meditação, na ontologia spinozista, não apenas a natureza essencial de Deus é demonstrada primeiro, como tudo que virá em seguida, incluindo a mente humana, deverá seguir da necessidade de sua

\footnotetext{
${ }^{8}$ SPINOZA, B. de. Ética, Parte I, proposição XVI, p. 75.

${ }^{9}$ Ibid., Parte I, Apêndice, p. 117.

${ }^{10}$ Ibid., Parte II, Introdução, p. 125.
} 
potência, enquanto efeitos imediatos que são imanentes à sua essência eterna e infinita. Além disso, ao afirmar que a mente humana é aquilo que segue necessariamente da essência de Deus, isso significa que a mente - ao contrário do caso cartesiano - não possui existência separada, nem tampouco distinta, da natureza divina. Na ontologia spinozista - em mais uma oposição à cartesiana não há separação substancial entre Deus e mente, o que significa entender que tudo que envolverá a natureza humana, não poderá ser concebido de outra maneira que não enquanto um modo da existência de Deus, uma expressão singular de sua potência eterna e infinita. Sendo assim, tudo o que irá se referir à natureza e origem da mente, também irá se referir, necessariamente, à natureza divina. Por isso, tal como acontece na Parte IV, em que Spinoza optou por demonstrar a força dos afetos a partir da impotência do homem (servidão humana), assim também a Parte II - ao que parece indicar o enunciado de seu breve texto introdutório - sugere que a natureza e a origem da mente será demonstrada a partir da potência que segue necessariamente da essência de Deus.

Com o título de Parte Segunda, da Natureza e Origem da Mente, Spinoza inicia o processo dedutivo que marca a passagem da natureza naturante para a natureza naturada. De fato, o próprio Spinoza torna isso evidente no breve texto que abre a Parte II.

\begin{abstract}
Passo agora a explicar o que deve seguir necessariamente da essência de Deus, ou seja, do Ente eterno e infinito. Decerto não tudo, já que na Proposição 16 da parte I demonstramos que dela seguem infinitas coisas em infinitos modos, mas apenas o que nos pode levar, como que pela mão, ao conhecimento da mente humana e de sua suma felicidade. ${ }^{11}$
\end{abstract}

Ainda que breve, as frases da pequena introdução não deixam dúvidas quanto às pretensões de Spinoza. "Explicar o que deve seguir necessariamente da essência de Deus", mesmo que não em sua totalidade, significa dizer que a Parte II da Ética continuará a demonstrar a natureza de Deus, só que agora enquanto constituição das coisas que seguem de sua natureza essencial. Trata-se da consolidação do momento em que Spinoza inicia a demonstração daquilo que ele - no segundo corolário, da proposição 16, da Parte I - se refere como sendo

${ }^{11}$ SPINOZA, B. de. Ética, Parte II, Introdução, p. 125. 
os atributos de Deus e as afecções dos atributos de Deus. Todavia, antes de iniciar a demonstração da Parte II, Spinoza esclarece, de imediato, que não irá tratar de tudo que segue necessariamente da essência de Deus, "mas apenas o que nos pode levar, como que pela mão, ao conhecimento da mente humana e sua suma felicidade" ${ }^{12}$. Esse detalhe é importante porque Spinoza havia estabelecido - também na proposição 16, da Parte I - que "da necessidade da natureza divina devem seguir infinitas coisas em infinitos modos (isto é, tudo que pode cair sob o intelecto infinito)" ${ }^{13}$ Porém, como não podemos conhecer tudo que pertence à natureza de Deus, é preciso considerar que dessas infinitas coisas, garante Spinoza, o homem só pode conhecer duas: o pensamento e a extensão. Sendo assim, a Parte II da Ética marca o início daquilo que podemos conhecer a partir dos dois atributos da natureza divina, isto é, o pensamento e a extensão.

\section{1 .}

\section{Sobre a estrutura da Parte II: uma breve descrição}

É opinião unânime de todos que querem saber além do vulgo que o método dos matemáticos para investigar e transmitir as ciências, isto é, aquele em que se demonstram as conclusões a partir das definições, postulados e axiomas, é a melhor e mais segura via para indagar e ensinar a verdade. ${ }^{14}$

Luís Meyer

A natureza e origem da mente, isto é, aquilo "que deve seguir necessariamente da essência de Deus, é demonstrada, na segunda parte da Ética, a partir de uma estrutura organizada em sete definições, cinco axiomas e quarenta e nove proposições. Além disso, intercalada entre as proposições 13 e 14, encontra-se uma estrutura à parte constituída por mais cinco axiomas, sete lemas, uma definição e um conjunto de seis postulados. Comumente chamada de "pequena física", essa estrutura é particularmente importante porque nela Spinoza apresenta sua dedução de corpo. Nessa primeira etapa de demonstração da natureza humana (precisamos lembrar que as partes subsequentes da Ética também se referem à natureza do homem), é possível observar que Spinoza divide as 49 proposições da Parte II a partir de dois aspectos diferentes da

\footnotetext{
${ }^{12}$ SPINOZA, B. de. Ética, Parte II, Introdução, p. 125.

${ }^{13}$ Ibid., Parte I, Proposição XVI, p. 75.

${ }^{14}$ Id., Princípios da filosofia cartesiana e Pensamentos metafísicos, Prefácio, p. 33.
} 
natureza da mente, sendo o primeiro dedicado à demonstração de suas propriedades essenciais e o segundo dedicado à demonstração de sua estrutura de pensamento.

Entre os estudos já apresentados sobre a segunda parte da Ética, destacamos os que foram desenvolvidos por Martial Guerout, na obra Spinoza II, L'Âme (Etique, II); Pierre Macherey, na obra Introduction à l'Éthique, de Spinoza: La seconde partie, la réalité mentale; Marilena Chaui, na obra $A$ nervura do real: imanência e liberdade em Espinosa, volume II: Liberdade. Esses três autores iniciam suas obras analisando as sete definições e os cinco axiomas, em separado. Em seguida, todos organizam a investigação das 49 proposições, separando-as em blocos temáticos específicos, cujo agrupamento é bastante semelhante entre eles. De maneira geral, é possível afirmar que tanto Gueroult, quanto Chaui, apresentam as 49 proposições da Parte II agrupadas em sete conjuntos, enquanto Macherey apresenta as mesmas 49 proposições divididas em cinco. Todavia, como esse estudo não se refere a uma investigação completa da Parte II da Ética, mas apenas - conforme aconselha Spinoza - "o que nos pode levar, como que pela mão, ao conhecimento da mente humana"15, a investigação que será apresentada a seguir não terá a pretensão de ir além das questões mais essenciais sobre a natureza da mente. Sendo assim, este estudo resumirá sua abordagem da Parte II aos dois aspectos principais que foram citados acima, isto é, as propriedades essenciais da mente e sua estrutura de pensamento. No primeiro caso, a investigação dará atenção especial aos desdobramentos da equiparação entre a potência dos atributos pensamento e extensão, durante o processo dedutivo da natureza essencial da mente (proposições de 1 a 13), enquanto, no segundo caso, será dada atenção especial aos desdobramentos da união entre a mente e o corpo, durante a demonstração da natureza da mente como modo de pensamento (proposições de 14 a 49).

A proposta de apresentar essa divisão temática é importante porque ela nos permite conhecer, ainda que resumidamente, os dois principais aspectos que constituem a primeira parte da dedução spinozista da natureza humana, isto é, a vida cognitiva, que, por sua vez, torna-se fundamental para o conhecimento da vida afetiva, na Parte III da Ética. Sendo assim, esse estudo entende que para

${ }^{15}$ SPINOZA, B. de. Ética, Parte II, Introdução, p. 125. 
uma abordagem mais direta sobre a natureza afetiva do homem, será preciso esclarecer, primeiro, que natureza humana é essa que Spinoza afirma seguir necessariamente da essência de Deus.

\subsection{2.}

\section{As definições da Parte II e a essência da mente}

A natureza e origem da mente é demonstrada, na Parte II da Ética, a partir de um conjunto formado por sete definições ${ }^{16}$ : "corpo" (definição 1); "pertencer à essência de uma coisa" (definição 2); "ideia" (definição 3); "ideia adequada" (definição 4); “duração" (definição 5); "realidade e perfeição" (definição 6); “coisas singulares" (definição 7). É preciso considerar que a estrutura de uma demonstração em ordem geométrica, por se tratar de um sistema dedutivo, exige que o conteúdo das demonstrações de suas partes deve seguir, necessariamente, das sínteses apresentadas por suas definições e axiomas. ${ }^{17}$ Também é preciso considerar que todas as definições de uma das partes do sistema - assim como os axiomas e postulados - são igualmente válidos para todas as demais. Dessa maneira, o processo dedutivo das proposições da Parte II, além de seguirem das sínteses de suas próprias definições e axiomas, também devem reafirmar a validade conceitual das sínteses apresentadas na Parte I, indicando uma espécie de continuidade do processo demonstrativo iniciado pelas definições e axiomas sobre Deus. Portanto, não é de se estranhar o breve texto introdutório anunciar que irá explicar "o que deve seguir necessariamente da essência de Deus". Ainda que a Parte II da Ética signifique a passagem da natureza naturante para

\footnotetext{
${ }^{16}$ As sete definições da segunda parte da Ética são: "Por corpo entendo o modo que exprime, de maneira certa e determinada, a essência de Deus enquanto considerada como coisa extensa" (definição 1); "Digo pertencer à essência de uma coisa aquilo que, dado, a coisa é necessariamente posta e, tirado, a coisa é necessariamente suprimida; ou aquilo sem o que a coisa não pode ser nem ser concebida e, vice-versa, que sem a coisa não pode ser nem ser concebido" (definição 2); "Por ideia entendo o conceito da mente, que a mente forma por ser coisa pensante." (definição 3); "Por ideia adequada entendo a ideia que, enquanto é considerada em si, sem relação ao objeto, tem todas as propriedades ou denominações intrínsecas da ideia verdadeira" (definição 4); "Duração é a constituição indefinida do existir" (definição 5); "Por realidade e perfeição entendo o mesmo" (definição 6); "Por coisas singulares entendo coisas que são finitas e têm existência determinada. Se vários indivíduos concorrem para uma única ação de maneira que todos sejam simultaneamente causa de um único efeito, nesta medida consideroos todos como uma única coisa singular" (definição 7). SPINOZA, B. de. Ética, Parte II, Definições, p. 125-127.

${ }^{17}$ No caso da quinta parte da Ética, por ela não possuir definições, seu processo dedutivo se inicia a partir de seu conjunto de axiomas.
} 
a natureza naturada, é preciso estar ciente de que seu conjunto de definições não inviabiliza a necessidade de uso do conjunto de definições da primeira parte da obra. A diferença é que, enquanto as definições da Parte I estabelecem a natureza daquilo que Spinoza denomina - no escólio da décima proposição, da Parte I - de o "ser da substância", as definições da Parte II dizem respeito à natureza "daquilo que segue necessariamente da essência de Deus", isto é, dizem respeito ao que Spinoza chama - na sétima definição, da Parte II - de “coisas singulares”. Na primeira parte da Ética, as definições permitem deduzir tudo aquilo que pertence à natureza de Deus, enquanto ente eterno e a substância constituída de infinitos atributos, em que cada um deles exprime uma essência eterna e infinita, isto é, Deus enquanto “ser da substância". Na segunda parte da obra, as definições permitem deduzir aquilo que "segue necessariamente da essência de Deus", isto é, as coisas que seguem de sua potência eterna e infinita. Decerto não tudo - como diz Spinoza no breve texto introdutório que inicia a Parte II - "mas apenas o que nos pode levar, como que pela mão, ao conhecimento da mente humana”. Sendo assim, a principal característica que demarca a diferença entre as definições das Partes I e II, é que, enquanto as definições da Parte I estabelecem Deus a partir da eternidade do ente absoluto, isto é, como "ser da substância", as definições da Parte II estabelecem Deus a partir das coisas que seguem de sua essência, isto é, aquilo que é formado a partir da só necessidade de sua potência, enquanto - tal como afirma Spinoza, no corolário da proposição 24, da Parte I - "causa do ser das coisas".

Conforme observado anteriormente, uma demonstração em ordem geométrica, como é de se esperar, indica que suas partes devem começar a partir das definições. Nesse sentido, o início da Parte II apresenta uma situação bastante singular, pois, conforme destaca Marilena Chaui, em A nervura do real II,

um curioso desequilíbrio parece percorrer a disposição das definições dessa Parte II, que trata 'Da natureza e da origem da mente humana'. De fato, Espinosa apresenta uma definição do corpo e uma da ideia, mas não oferece uma definição da mente, que é, entretanto, o objeto central dessa segunda parte, cujo o título é 
De natura et origine mentis. Mais do que isso, a mente, que não é definida, é, entretanto, invocada para a definição de ideia. ${ }^{18}$

Considerando a afirmação que Spinoza apresenta no Tratado da emenda do intelecto (ou Tratado da reforma da inteligência), de que "[...] a reta via da descoberta é formar pensamentos a partir de alguma definição dada, o que se processará tanto mais feliz e facilmente quanto melhor houvermos definido alguma coisa",19, ou ainda quando afirma que "a definição, para que seja dita perfeita, deverá explicar a essência íntima da coisa e precaver-nos para que não usemos no lugar desta alguns próprios", ${ }^{20}$ as definições, portanto, devem atuar exclusivamente como "explicações" da natureza essencial (ou "essência íntima") da coisa definida. No segundo escólio, da proposição 8, da Parte I, Spinoza apresenta uma descrição ainda mais detalhada sobre a importância das definições, dessa vez por meio de uma abordagem conceitual ainda mais técnica, com características mais apropriadas ao texto da Ética.

[...] I. A verdadeira definição de cada coisa nada envolve nem exprime exceto a natureza da coisa definida. Disto segue II. que nenhuma definição envolve nem exprime um certo número de indivíduos, visto que nada outro exprime senão a natureza da coisa definida. III. É de notar que de cada coisa existente é dada necessariamente uma certa causa pela qual existe. IV. Enfim, é de notar que esta causa, pela qual alguma coisa existe, ou deve estar contida na própria natureza e definição da coisa existente (não é de admirar, já que à sua natureza pertence existir), ou deve ser dada fora dela $[\ldots] .{ }^{21}$

Portanto, conforme sua própria descrição, como as definições da Ética "não envolve[m] nada além do que a natureza essencial da coisa definida", é importante ressaltar que será necessário, então, que todas as definições do sistema cumpram com determinadas condições para serem consideradas verdadeiras, tais como, por exemplo, excluir qualquer ambiguidade entre os termos definidos, o que implica a verificação das condições de inteligibilidade desses termos. Desse modo, tal como ocorre com os entes da geometria, os entes metafísicos das definições da Ética precisarão atuar de maneira decisiva durante a explicação da natureza essencial da coisa definida, pois as definições

\footnotetext{
${ }^{18}$ CHAUI, M. A nervura do real II: imanência e liberdade em Espinosa, p. 94.

${ }^{19}$ SPINOZA, B. de. Tratado da emenda do intelecto, $\$ 94$, p. 85.

${ }^{20}$ Ibid., $\$ 95$, p. 85.

${ }^{21}$ Id., Etica, Parte I, Proposição VIII, Escólio II, p. 55.
} 
precisarão "orientar" os demais elementos do método geométrico para que eles possam garantir a validade do que está sendo deduzido nas proposições, ou, como argumenta Gueroult, "os pressupostos da Philosophia são investidos de uma evidência ao menos igual àquela dos pressupostos da Geometria." [tradução do autor]. ${ }^{22}$ Dessa maneira, tal como ocorre com as definições da geometria, as definições da Ética também precisam garantir, apenas por força da natureza essencial da coisa definida, a real existência do objeto ao qual se referem, ou, em outras palavras, devem anunciar ou determinar o que verdadeiramente caracteriza a essência de uma coisa e a causa que faz essa coisa ser exatamente o que é.

Dada a importância que as definições representam para o processo dedutivo da Ética, torna-se curioso, portanto, o fato de Spinoza não ter apresentado uma definição para a mente na Parte II, tal como fez para o corpo, por exemplo. Alguns estudiosos da filosofia spinozista, sugerem certas razões que explicam a ausência da definição de mente, no conjunto de definições da Parte II. Todavia, mediante o objetivo aqui pretendido, não será necessário investigar quais seriam essas razões. Em nosso caso, basta esclarecer que o enunciado do breve texto introdutório não deixa dúvidas de que a mente, independente de qualquer coisa, deve ser entendida como aquilo que segue necessariamente da essência do ente absolutamente infinito, ou seja, Deus, sendo isso sua natureza essencial, o que, em tese, justifica o título: Da natureza e origem da mente. Sendo assim, devemos concluir que se o início da Parte II não apresenta uma definição da mente, é porque faz parte de sua natureza “demonstrar por que e como a mente humana é um modo singular do atributo pensamento, portanto uma ideia que forma ideias, e determinar aquilo de que ela é ideia: ideia das afecções do corpo e ideia das ideias dessas afecções." ${ }^{23} \mathrm{Em}$ outras palavras, na abertura da parte da Ética que terá a mente como tema, encontramos um enunciado que estabelece a mente como sendo ela própria, uma potência da necessidade essencial do ente eterno que, após ser concebido enquanto "ser da substância", na Parte I, torna-se agora, na Parte II, causalidade necessária da existência de todas as coisas que seguem de sua natureza

\footnotetext{
22 “[...] les présupposés de la Philosophie sont investis d'une évidence au moins égale à celles des présupposés de la Géométrie." GUEROULT, M. Spinoza. vol. 1 (Dieu), p. 36.

${ }^{23}$ CHAUI, M. A nervura do real II: imanência e liberdade em Espinosa, p. 102.
} 
essencial, inclusive daquilo que é a própria "via" de expressão dessa potência, isto é, a mente humana.

A ausência de uma definição nos coloca diante de um conceito de mente em que sua existência real e sua natureza essencial expressam uma só e mesma coisa. “[...] É de notar que a causa pela qual alguma coisa existe, ou deve estar contida na própria natureza e definição da coisa existente, ou deve ser dada fora dela." ${ }^{24}$ Nessa perspectiva, se não temos uma definição que nos permite conhecer a natureza essencial da mente, certamente é porque essa essência se encontra "fora dela", o que de certa maneira pode ser justificado por um enunciado que estabelece a mente como "aquilo que deve seguir necessariamente da essência de Deus". A existência da mente, isto é, sua essência, poderá ser deduzida à medida em que ela expressa a própria essência de Deus, no interior dos modos singulares. Aqui, o mais importante para as pretensões deste estudo é observar que, apresentada desta maneira, é possível entender, não apenas porque a mente não necessita de uma definição própria, como também porque ela é o tema principal da segunda parte da Ética, pois, onde existir algo que de alguma maneira envolva a natureza humana, certamente a mente também estará envolvida. E é exatamente isso que iremos observar, mais adiante, quando investigarmos as questões que dizem respeito à relação mente-corpo, assim como aquelas relacionadas à vida cognitiva.

\subsection{3.}

\section{Os axiomas da Parte II e as propriedades universais da mente}

Sabemos que, por se tratar de uma demonstração em ordem geométrica, o uso dos axiomas, na Ética, é inspirado e segue o mesmo método utilizado por Euclides, na obra Elementos. Também sabemos que um axioma,

em termos geométricos, é um universal - oferece uma propriedade universal; uma verdade eterna, isto é, aquela cujo o contraditório é impossível; e um operador ou uma regra de demonstração - permite conectar de maneira necessária uma definição e uma proposição ou teorema no processo dedutivo. ${ }^{25}$

\footnotetext{
${ }^{24}$ SPINOZA, B. de. Ética, Parte I, Proposição VIII, Escólio II, p. 55.

${ }^{25}$ CHAUI, M. A nervura do real II: imanência e liberdade em Espinosa, p. 103.
} 
Na demonstração em ordem geométrica, tal como utilizada na Ética, a diferença entre definição e axioma é que, enquanto a definição - conforme afirma o próprio Spinoza - "nada envolve nem exprime exceto a natureza da coisa definida", ${ }^{26}$ isto é, sua essência; o axioma, por sua vez, estabelece a propriedade universal daquilo que é tema do enunciado axiomático. Os axiomas da Parte II, por se referirem à mente, irão estabelecer as propriedades universais daquilo que segue necessariamente da essência de Deus, ou seja, seus modos singulares. $^{27}$

Tanto na obra de Spinoza, quanto na de Euclides, os axiomas e postulados estão situados entre as definições e as proposições. No caso de Spinoza, em todas as partes da Ética foi utilizada a denominação "axiomas", exceto em dois momentos: após as definições da Parte III e após o Lema 7 da "pequena física" intercalada entre as proposições 13 e 14, da Parte II. Nesses dois momentos, Spinoza optou por utilizar a expressão "postulados" para nomear o grupo de sínteses apresentado após as definições. Por fim, é preciso observar que, se por um lado o conjunto de sete definições da segunda parte da Ética possibilitam o conhecimento da natureza essencial do "que deve seguir necessariamente de Deus", ou seja, aquilo que permitirá o conhecimento da natureza essencial da mente, o conjunto de cinco axiomas auxiliará na dedução de todas as propriedades que seguem dessa natureza essencial.

Uma vez esclarecido como Spinoza organizou os dois grupos de sínteses que iniciam a Parte II, passaremos, então, à investigação de como ele irá conforme suas próprias palavras - nos conduzir "como que pela mão, ao conhecimento da mente humana e de sua suma felicidade". ${ }^{28}$

\footnotetext{
${ }^{26}$ SPINOZA, B. de. Ética, Parte I, Proposição VIII, Escólio 2, p. 55.

${ }^{27}$ Os axiomas da Parte II da Ética são: "A essência do homem não envolve existência necessária, isto é, pela ordem da natureza tanto pode ocorrer que este ou aquele homem exista como não exista" (axioma 1); "O homem pensa" (axioma 2); "Modos de pensar como amor, desejo, ou qualquer outros que sejam designados pelo nome de afeto do ânimo, não se dão se no mesmo indivíduo não se der a ideia da coisa amada, desejada, etc. Mas a ideia pode dar-se ainda que não se dê nenhum outro modo de pensar" (axioma 3); "Sentimos um corpo ser afetado de muitas maneiras" (axioma 4); "Não sentimos nem percebemos nenhuma coisa singular além de corpos e modos de pensar" (axioma 5). Ibid., Parte II, Axiomas, p. 127-129.

${ }^{28}$ Ibid., Parte II, Introdução, p. 125.
} 


\title{
2.2. \\ As proposições iniciais da Parte II e a mente como expressão dos atributos pensamento e extensão
}

\begin{abstract}
A coisa extensa e a coisa pensante são ou atributos de Deus ou afecções dos atributos de Deus $[\ldots] .{ }^{29}$
\end{abstract}

Spinoza

Sabemos que entre os comentadores da Parte II da Ética que foram destacados por este estudo, todos indicam - cada um a sua maneira - o conjunto de proposições de 1 a 13 como sendo a primeira etapa da dedução da natureza da mente. Gueroult entende esse trecho como sendo a "Dedução da essência do homem". Macherey classifica como "De Deus à alma humana". Chaui, por sua vez, apresenta uma pequena subdivisão, separando o conjunto em dois blocos, sendo o primeiro formado pelas proposições de 1 a 10, cujo tema ela denomina de "Fundamentos ontológicos da natureza do corpo e da mente", enquanto o segundo, composto pelas proposições de 11 a 13, ela chama de "A natureza da mente". Apesar da aparente diferença de abordagem que os títulos sugerem, o fato é que se pode observar que os três autores são unânimes em indicar o mesmo conjunto de proposições (de 1 a 13) como sendo o primeiro momento da dedução spinozista da natureza da mente. Contudo, como este estudo se refere apenas aos aspectos da vida cognitiva, a investigação que será apresentada a seguir tentará extrair desse conjunto de proposições, somente aquilo que diz respeito às coisas singulares e seu processo de constituição da natureza humana. Dessa maneira, se nossa proposta inicial tem como objetivo conhecer o aspecto cognitivo da natureza humana, para depois entender como ela se integra à vida afetiva, então será preciso conhecer, primeiro, como essa natureza humana se origina a partir daquilo que segue necessariamente da potência de Deus, enquanto expressão de sua essência.

Spinoza inicia a dedução da mente, na Parte II, anunciando na primeira proposição que “o pensamento é atributo de Deus, ou seja, Deus é coisa pensante. ${ }^{30}$ Em seguida, estabelece, na segunda proposição, que "a extensão é atributo de Deus, ou seja, Deus é coisa extensa." ${ }^{31}$ As duas proposições não

\footnotetext{
${ }^{29}$ SPINOZA, B. de. Ética, Parte I, Proposição 14, Corolário II, p. 67.

${ }^{30}$ Ibid., Parte II, Proposição I, p. 129.

${ }^{31}$ Ibid., Parte II, Proposição II, p. 129.
} 
deixam dúvidas em relação aos objetivos pretendidos por Spinoza nessa parte da obra: trata-se da ontologia que permitirá deduzir as coisas singulares como aquilo que segue necessariamente da natureza divina. $\mathrm{Na}$ perspectiva da natureza humana, essas proposições são particularmente importantes porque elas estabelecem aquilo que podemos conhecer da substância, como expressão de sua essência eterna e infinita, nos modos singulares. Tanto o pensamento quanto a extensão são deduzidos como "atributos de Deus". Porém, Spinoza apresenta uma demonstração, na primeira proposição - que também é válida para a segunda - em que deixa claro que essa dedução se refere a pensamentos e extensões "singulares", se tratado, pois, de modos certos e determinados da natureza de Deus. Ora, considerando que por atributo Spinoza entende "aquilo que o intelecto percebe da substância como constituindo a essência dela"32, o pensamento e a extensão, deduzidos como atributos de Deus na abertura da segunda parte, indica claramente que na mente não haverá separação entre a natureza essencial que pertence ao ser da substância e sua existência necessária nos modos singulares. Sendo assim, o atributo pensamento irá envolver o conceito de todas as ideias que seguem da essência eterna da substância absolutamente infinita, assim como o atributo extensão envolverá o conceito de todas as ideias que seguem das afecções da substância.

Os atributos pensamento e extensão são expressões do que segue da essência de Deus, porém não mais como propriedades independentes do ser da substância, tal como demonstrados na primeira parte da Ética, mas agora como atributos que juntos constituem as coisas singulares. Por isso, é possível afirmar que nas primeiras proposições da Parte II, Spinoza já se refere a uma modalidade da realidade divina que está intrinsecamente ligada à natureza humana, e essa conexão surge à medida que os dois atributos se expressam por meio de pensamentos e extensões singulares, e esses, por sua vez, são concebidos pela mente humana sob a forma de ideias. Trata-se de uma reformulação conceitual, pois os dois atributos, antes independentes na natureza essencial do ser da substância, na primeira parte, tornam-se agora, em conjunto, na Parte II, constituição ontológica de todos os modos singulares. Porém, é

\footnotetext{
${ }^{32}$ SPINOZA, B. de. Ética, Parte I, Definição IV, p. 45.
} 
preciso esclarecer que isso não significa, necessariamente, que as coisas singulares surgem a partir de uma espécie de "paralelismo" entre os atributos pensamento e extensão, tal como alguns estudiosos sugerem, principalmente nas investigações sobre a sétima proposição (retornaremos a essa questão mais adiante). Dificilmente poderemos chegar numa conclusão plenamente satisfatória sobre a questão da equiparação entre a potência dos atributos pensamento e extensão se referirem ou não a um paralelismo. Em nosso caso, no entanto, o mais importante é esclarecer que nos modos singulares os atributos pensamento e extensão, por estarem conectados entre si, são concebidos simultaneamente, originando uma espécie de complementaridade necessária ao próprio conceito de mente, conceito no qual ambos os atributos são causa imediata. Não se trata, portanto, de uma ordenação em que a existência de um independe da existência do outro, como ocorre no ser da substância, mas de uma simultaneidade que afirma a potência de Deus por meio de ambos os atributos, no interior de um mesmo e único modo singular.

Após as duas primeiras proposições afirmarem os atributos pensamento e extensão como fundamento ontológico das coisas que seguem necessariamente da essência de Deus, isto é, os modos singulares, Spinoza começa - a partir do conjunto de proposições de 3 a 13 - a dedução da natureza essencial da mente e sua potência de pensar. De maneira geral, é possível afirmar que esse conjunto de proposições é dedicado a deduzir como operam os atributos pensamento e extensão, no interior da constituição das ideias que envolvem os modos singulares. É preciso destacar que o trecho que vai até a décima terceira proposição, da Parte II, se refere às propriedades da mente como modos do atributo pensamento. Observa-se que nesse trecho da obra, Spinoza ainda não se refere ao corpo, o que só irá acontecer mais adiante, na chamada "pequena física", intercalada entre as proposições 13 e 14. Por isso, todas as proposições do conjunto de 3 a 13 referem-se apenas à dedução dos princípios que explicam as "operações" da mente, de como ela produz suas ideias. Daí a importância dos comentadores da Parte II, citados por essa pesquisa, indicarem o conjunto de proposições de 1 a 13 como se referindo à natureza essencial da mente. Trata-se da demonstração de como os infinitos atributos que seguem do intelecto divino atuam na constituição das ideias singulares, enquanto modos de pensamento. 
$\mathrm{Na}$ demonstração que segue à terceira proposição, fica claro que é a potência de poder pensar infinitas coisas em infinitos modos, que permite Deus produzir, ele próprio, "a ideia de sua essência e de tudo que dela segue necessariamente" 33 . E como pertence à natureza da mente, ser aquilo que segue da essência de Deus, isto é, do intelecto divino, também será parte de sua natureza poder produzir a ideia, tanto dos atributos que exprimem a essência de Deus, quanto das afecções que exprimem os modos certos e determinados da natureza divina. A potência da mente, portanto, será capaz de expressar conforme afirma o próprio Spinoza - "tudo que está no poder de Deus." ${ }^{34}$ Dessa maneira, tudo aquilo que segue da essência de Deus, isto é, "tudo aquilo que está em seu poder" e a potência da mente de poder conceber as ideias cujo atributos expressam a essência divina, se tornam uma só e mesma potência. Nesse sentido, contrariamente à concepção cartesiana, em que a descoberta da coisa que pensa acontece antes da descoberta de Deus, abrindo caminho para uma dedução negativa da mente, pois ela precisa partir da dúvida e suspensão do juízo (primeiro movimento da teoria do cogito), para então alcançar a certeza das ideias claras e distintas da natureza divina, reafirmando, assim, a mente positivamente, Spinoza, por sua vez, afirma a mente positivamente de maneira imediata, uma vez que ele, ao contrário de Descartes, demonstra a existência de Deus primeiro para então deduzir a mente como aquilo que segue necessariamente da essência divina, garantindo, assim, a simultaneidade entre a essência de Deus e a potência da mente de poder expressar seus atributos. Como esclarece Gueroult, em L'Âme:

Enquanto Descartes trata primeiro Da Natureza da alma humana (Meditação Segunda) e em seguida De Deus (Meditação terceira), Spinoza, como alguns já observaram, só trata Da Natureza e Origem da alma (Parte II, da Ética), após ter tratado De Deus (Parte I, da Ética). Inversão fundada, uma vez que Deus, conhecendo a si mesmo e conhecendo seus modos ao mesmo tempo que os produz, é para a alma, que ele contém como uma das ideias de seu entendimento, único princípio possível, não apenas de seu ser, mas da consciência que ela toma dela mesma e das coisas." [tradução do autor]. ${ }^{35}$

\footnotetext{
${ }^{33}$ SPINOZA, B. de. Ética, Parte II, Proposição III, Demonstração, p. 131.

${ }^{34}$ Ibid.

35 “Alors que Descartes traite d'abord 'De la Nature de l'âme humaine' (II' Méditation), et ensuite 'De Dieu' (III Méditation), Spinoza, comme d'aucuns l'ont remarqué, ne traite 'De la Natures et de l'Origine de l'Ame' (II' Livre de l'Ethique) qu'après avoir traité 'De Dieu' (I' Livre). Inversion fondée, puisque Dieu, se connaissant et connaissant ses modes en même temps qu'il les produit, est pour l'Ame, qu'il contient comme une des idées de son entendement,
} 
A mente, por ser aquilo que segue necessariamente da essência de Deus, é concebida positivamente porque ela expressa, tanto o conhecimento da natureza essencial do objeto de suas ideias, quanto o conhecimento das modificações desses objetos, à medida que eles são produzidos, de maneira simultânea e imediata, a partir da só necessidade da natureza divina. Além disso, sendo a mente uma das infinitas coisas que seguem da natureza essencial de Deus, pelos quais ele exprime sua essência eterna e infinita, nesse sentido Spinoza também afasta qualquer possibilidade de contingência da natureza da mente, algo que o primeiro corolário da proposição 16 , da primeira parte, já havia esclarecido ao anunciar que: "Daí segue que Deus é causa eficiente de todas as coisas que podem cair sob o intelecto"36. Ainda que a mente tenha potência para conceber as ideias que seguem necessariamente da natureza essencial de Deus, isso não significa que a mente concebe essa ou aquela ideia em vista de um determinado fim, pois, conforme esclarece Spinoza, no apêndice da Parte I,

[...] os homens comumente supõem que as coisas naturais agem, como eles próprios, em vista de um fim; mais ainda, dão por assentado que o próprio Deus dirige todas as coisas para algum fim certo: dizem, com efeito, que Deus fez tudo em vista do homem, e o homem, por sua vez, para que o cultuasse. ${ }^{37}$

Mediante isso, sobre a hipótese de a mente ter sua natureza concebida separada do conhecimento daquilo que é causa de sua origem, Spinoza não hesita em afirmar que "[...] poderia aqui mostrar que aquela potência que o vulgar imputa a Deus não apenas é humana (o que mostra que o vulgar concebe Deus como homem ou à semelhança de um homem), mas também envolve impotência." 38 A concepção spinozista de mente é positiva porque ela é concebida a partir da potência de Deus e não somente a partir da natureza humana. E como a mente é "aquilo que deve seguir necessariamente da essência de Deus", com isso Spinoza não só afasta a contingência das ideias concebidas pela mente, pois elas possuem causalidade necessária, portanto não contingente, como também afasta o finalismo, uma vez que a mente jamais concebe ideias

l'unique principe possible, non seulement de son être, mais de la conscience qu'elle prend d'elle-même et des choses. GUEROULT, M. Spinoza II. L'âme. (Ethique, II), p. 7.

${ }^{36}$ SPINOZA, B. de. Ética, Parte I, Proposição XVI, Corolário I, p. 75.

${ }^{37}$ Ibid., Parte I, Apêndice, p. 111.

${ }^{38}$ Ibid., Parte II, Proposição III, Escólio, p. 131. 
em vista de uma finalidade própria, mas tão somente em função de sua natureza essencial, que é expressar a essência de Deus. As ideias concebidas pela mente da concepção spinozista será sempre o resultado da atividade de um intelecto que age (no sentido de afirmar ou negar suas ideias), à medida em que a mente se encontra internamente disposta a querer conhecer as causas de suas afecções, isto é, as coisas que ela percebe, não apenas porque é uma coisa que pensa, mas por ser capaz de poder afirmar ou negar as coisas que pensa.

Sendo assim, as proposições iniciais da Parte II deduzem a natureza da mente positivamente, em seu sentido mais forte, como aquilo que segue necessariamente da potência de Deus. E a estrutura que garante a autonomia dessa potência é demonstrada logo em seguida, nas proposições 4 e 5. Primeiro, ao enunciar que a "ideia de Deus, da qual seguem infinitas coisas em infinitos modos, só pode ser única"39 (quarta proposição). Depois ao enunciar que o "ser formal das ideias reconhece como causa Deus apenas enquanto considerado como coisa pensante, e não enquanto explicado por outro atributo.[...]"40 (quinta proposição). As duas proposições atuam no sentido de confirmar a potência de Deus como coisa pensante. Trata-se da atividade do intelecto divino ou da ciência de Deus. “Ora, Deus é único. Logo, a ideia de Deus, da qual seguem infinitas coisas em infinitos modos, só pode ser única”, afirma Spinoza, na demonstração da quarta proposição. Como da ideia de Deus seguem "infinitas coisas em infinitos modos", Deus, enquanto ideia única, abre caminho para que seus atributos e as afecções desses atributos - antes propriedades essenciais pertencentes ao ser da substância - tornem-se, agora, expressões singulares do intelecto divino ou, como diz Spinoza - no final do enunciado da quinta proposição - de "Deus enquanto considerado como coisa pensante". Com efeito, as ideias da mente terão um "ser formal" e esse "ser" será reconhecido, primeiro como algo que terá sua causa em Deus, segundo como algo que expressa sua ideia, enquanto constituição de seu intelecto eterno e infinito nos pensamentos singulares. Dessa maneira, Spinoza, mais uma vez, afasta o finalismo das ideias produzidas pela mente, uma vez que a causa da origem das ideias (seu "ser formal"), jamais poderá ser conhecida por meio dos ideados, isto é, através da

\footnotetext{
${ }^{39}$ SPINOZA, B. de. Ética, Parte II, Proposição IV, p. 133.

${ }^{40}$ Ibid., Parte II, Proposição V, p. 133.
} 
maneira como a mente "percebe" as coisas das quais produz a ideia, mas tão somente através dos atributos que exprimem a natureza de Deus de maneira certa e determinada.

O ser formal das ideias é modo de pensar (como é conhecido por si), isto é, modo que exprime de maneira certa a natureza de Deus enquanto coisa pensante, e por isso não envolve o conceito de nenhum outro atributo de Deus, e consequentemente não é efeito de nenhum outro atributo senão o pensamento, por isso o ser formal das ideias reconhece como causa Deus apenas enquanto considerado como coisa pensante etc. ${ }^{41}$

Ora, enquanto atividade do intelecto, as ideias haverão de reconhecer em si mesmas, o "ser" que é causa de sua origem. A quinta proposição não deixa dúvidas de que a causa que dá origem ao ser formal das ideias da mente, jamais poderá ser encontrada na percepção das coisas ideadas. Com efeito, é na potência que o intelecto divino possui de poder expressar seus infinitos atributos através das ideias singulares, que a mente humana poderá reconhecer, na própria essência de Deus, o "ser formal" que dá origem às ideias que são por ela concebidas. Nesse sentido, a sexta proposição, ao anunciar que "os modos de qualquer atributo têm como causa Deus enquanto considerado apenas sob aquele atributo de que são modos, e não enquanto considerado sob algum outro" 42 , surge para reafirmar a potência que os atributos possuem de poder expressar a essência de Deus, por meio de seus infinitos modos. Tal conjuntura permite que a essência infinita de Deus também exista na realidade de seus modos singulares, realidade essa, que é a mesma que é concebida pelo intelecto humano. Isso porque, ao afirmar que "os modos de qualquer atributo têm como causa Deus", Spinoza indica que os atributos se expressam através de seus modos determinados e são eles - os modos de Deus - que a mente humana reconhece como constituição do ser formal de suas ideias.

Cada atributo é uma ordem de realidade própria que se exprime em seus modos determinados, isto é, cada um deles é uma potência infinita de produção imanente de efeitos certos e determinados. Consequentemente, o universo é uma rede de diferentes ordens de realidade que exprimem numa complexidade

\footnotetext{
${ }^{41}$ SPINOZA, B. de. Ética, Parte II, Proposição V, Demonstração, p. 133.

${ }^{42}$ Ibid., Parte II, Proposição VI, p. 135.
} 
infinitamente diferenciada a potência única da substância absolutamente infinita. ${ }^{43}$

Cada atributo sendo, portanto, "uma ordem de realidade própria que se exprime em seus modos determinados", e sendo cada um deles uma potência de produção de efeitos que exprimem singularmente "a potência única da substância absolutamente infinita", isso significa afirmar que a substância atua diretamente na constituição das coisas singulares, na medida em que expressa os infinitos atributos que seguem da essência de Deus, enquanto "modos da substância”. Sendo assim, a sexta proposição confirma a autonomia causal dos atributos. As ideias concebidas pela mente humana são os modos pelos quais os atributos se expressam no pensamento. Um atributo possui autonomia para reproduzir, em seus modos, todos os efeitos que seguem da essência infinita de quem são expressão, e esses efeitos jamais poderão ser produzidos pela ação de outro atributo ou de qualquer outro modo da substância, como a extensão, por exemplo. O intelecto divino, portanto, é causa eficiente, tanto das ideias que seguem necessariamente dos infinitos atributos de Deus, quanto das ideias que seguem de seus infinitos modos, simultaneamente. Nesse sentido, cada atributo é capaz de garantir, apenas por si mesmo, a manutenção da integridade da essência de Deus, ao mesmo tempo que é causa dos efeitos que seguem da expressão dessa essência, nos modos que constituem as afecções da substância. Daí a importância da autonomia dos atributos na constituição da potência de pensar da mente, pois, ao expressarem o pensamento infinito de Deus, os atributos também produzem seus efeitos na duração de seus modos finitos, isto é, nas ideias dos pensamentos singulares que a mente concebe de cada atributo que expressa as afecções da substância, ou, dito de outra maneira, cada um dos atributos que expressam as modificações da substância, isto é, que expressam as modificações da realidade de sua existência. Por isso Spinoza afirma - no escólio da proposição 10, da primeira parte - "que nada é mais claro na natureza quanto dever cada ente conceber-se sob algum atributo, e quanto mais realidade ou ser tenha; tanto mais atributos tem, os quais exprimem necessidade, ou seja, eternidade e infinidade [...]". ${ }^{44}$

\footnotetext{
${ }^{43}$ CHAUI, M. A nervura do real II: imanência e liberdade em Espinosa, p. 112.

${ }^{44}$ SPINOZA, B. de. Ética, Parte I, Proposição X, Escólio, p. 59.
} 
Demarcando seu distanciamento do modelo cartesiano, em que a mente se encontra separada de Deus, Spinoza, ao apresentar um conceito em que a mente segue necessariamente da essência do ente eterno e infinito, ele faz da mente humana uma expressão do intelecto divino. Dessa maneira, Spinoza concebe uma atividade cognitiva em que para cada modo certo e determinado que expressa a essência de Deus, isto é, as afecções da substância, um atributo é produzido pelo intelecto infinito, e este, por sua vez, precisará expressar, na mente humana, outro atributo capaz de modificar as ideias de quem concebe esses modos. Ao fim do processo, tanto os atributos das afecções da substância, quanto as modificações das ideias na mente de quem os concebe, serão afetados simultaneamente por tais afecções. Deus e seus infinitos modos formam, portanto, uma só e mesma existência, assim como suas afecções e os atributos dessas afecções, também formam uma só e mesma modificação. Com isso, Spinoza nos coloca diante das condições ideais para iniciar a demonstração de um dos momentos mais importantes de sua filosofia, que é a sequência de proposições que deduzem a relação existente entre a ordem e a conexão das ideias e das coisas, no interior do processo de constituição dos modos singulares. Portanto, a partir da sétima proposição, veremos o início do processo que nos conduzirá - conforme indicou Spinoza no breve texto introdutório da Parte II - "como que pela mão", ao conhecimento da natureza humana, isto é, a vida cognitiva e a vida afetiva.

Contudo, antes de seguir adiante, é preciso concluir que Spinoza conforme vimos acima - ao demonstrar a autonomia dos atributos a partir de seus modos, está demonstrando claramente que seu modelo de natureza humana está amplamente conectado à natureza divina, e a principal ligação entre as duas naturezas, certamente, encontra-se na potência que a mente humana possui de poder conceber os atributos que exprimem, tanto as essências eternas da substância infinita, quanto as afecções de suas modificações. Em vista dos objetivos pretendidos por este estudo, isso é extremamente importante porque demonstra a potência que a mente humana possui de poder conceber os atributos que expressam tudo o que segue do intelecto divino, incluindo suas modificações, o que afeta diretamente a realidade humana. Sendo assim, a mente, ao conceber as ideias acerca das afecções da substância, concebe 
também todas as ideias acerca de suas próprias afecções. Dessa maneira, se o modo humano de existência é marcado por uma dinâmica em que sua realidade resulta dos atributos que expressam as modificações da substância, certamente, essa dinâmica, na perspectiva da natureza humana, também será marcada pelas modificações das ideias dos pensamentos singulares, isto é, pelas ideias que a mente concebe acerca de suas próprias afecções (mais adiante veremos que se trata das afecções do corpo existindo em ato). Ou seja, ainda estamos falando da potência de pensar da mente, mas, considerando a questão a partir da perspectiva da natureza humana, já é possível observar que se trata de uma dinâmica que também envolverá afecções singulares.

\subsection{1. \\ A mesma ordem e a mesma conexão das ideias e das coisas e o conhecimento dos modos singulares}

Conforme afirmado anteriormente, após garantir a autonomia dos atributos a partir de seus modos, Spinoza apresenta aquela que é considerada por muitos estudiosos de sua filosofia, uma das proposições mais importantes da Ética: a sétima proposição da Parte II. Sabemos que essa importância se deve ao fato de o conteúdo da proposição (principalmente seu corolário) estar no centro de um intenso debate acerca da existência ou não, de um "paralelismo" entre os atributos pensamento e extensão. Certamente, todo estudo que envolva a sétima proposição da Parte II, precisará considerar a hipótese do paralelismo, principalmente porque - conforme destacado anteriormente - as proposições iniciais da Parte II da Ética, por envolverem uma equiparação entre a potência dos atributos pensamento e extensão, no interior dos modos singulares, teria seu conteúdo orientado pela noção de um provável paralelismo envolvendo ambos os atributos. Contudo, como nosso interesse pela sétima proposição se refere apenas ao entendimento sobre o significado da equiparação entre a ordem e a conexão das ideias e das coisas, tão somente em seu contexto para o processo dedutivo da Parte II, cujo sentido primordial de suas proposições inicias, não devemos esquecer, se referem à dedução da natureza essencial da mente, não iremos nos aprofundar no debate acerca das questões relacionadas ao "paralelismo", tal como sugerido pelos estudos desenvolvidos sobre o tema. 
Inicialmente, é importante observar que tanto o enunciado da sétima proposição: "A ordem e conexão das ideias é a mesma que a ordem e conexão das coisas" ${ }^{\prime 4}$, quanto sua demonstração e corolário, são relativamente breves. Mas, em seu escólio, encontramos uma explicação que esclarece mais detalhadamente o significado dessa ordem e conexão que a proposição afirma existir entre as ideias e as coisas. Porém, antes da investigação sobre a explicação do escólio, é importante destacar que, tanto na demonstração, quanto no corolário, há um detalhe que é fundamental para esclarecer com maior precisão o funcionamento desse processo de ordenação. Marilena Chaui, na obra A nervura do real II, nos lembra que na demonstração da proposição 7 "Spinoza se limita a invocar o quarto axioma da Parte I, isto é, que o conhecimento de um efeito depende do conhecimento de sua causa e o envolve."46 (Abordaremos a presença desse axioma, mais adiante). Ela também nos lembra que o enunciado da proposição não explica por que a ordem e a conexão das ideias é a mesma que a ordem e a conexão das coisas, o que só irá acontecer - conforme já antecipamos - no escólio. Sobre a questão do corolário, a autora destaca que:

\begin{abstract}
As controvérsias suscitadas pelo corolário da sétima proposição não se esgotam na equivocada suposição da potência "maior" do atributo pensamento em relação aos demais atributos. Na verdade, elas decorrem de uma outra controvérsia, mais antiga, duradoura e tenaz, vinda da malfadada noção de "paralelismo" aplicada à filosofia de Spinoza, noção que é responsável, ao fim e ao cabo, pela imagem do desequilíbrio do sistema, provocando pela suposta potência "maior" do atributo pensamento. O corolário da proposição 7 da Parte II equipara a potência dos atributos (a ordem e conexão das ideias e das coisas é a mesma, e a potência divina de pensar e de agir é igual); em contrapartida, o "paralelismo" os coloca numa relação de correspondência de biunívoca. De onde vem a suposição de que os atributos seriam "paralelos"? Sem dúvida, do emprego de uma ideia leibniziana do "aqui como lá" aplicada à proposição $7 .{ }^{47}$
\end{abstract}

Deixando de lado a questão do paralelismo, é importante notar que Chaui chama atenção para o fato de que o corolário da sétima proposição "equipara a potência dos atributos (a ordem e conexão das ideias e das coisas é a mesma, e a potência divina de pensar e de agir é igual)". Vimos que, nas proposições anteriores, Spinoza já havia deduzido a autonomia dos atributos. Uma vez realizado esse trabalho, a sétima proposição surge para estabelecer - conforme

\footnotetext{
${ }^{45}$ SPINOZA, B. de. Ética, Parte II, Proposição VII, p. 135.

${ }^{46}$ CHAUI, M. A nervura do real II: imanência e liberdade em Espinosa, p. 113.

${ }^{47}$ Ibid., p. 117.
} 
destaca Chaui - a "equiparação" de suas potências, no interior da constituição dos modos singulares. De fato, o corolário, ao afirmar que: "Donde segue que a potência de pensar de Deus é igual a sua potência atual de agir. Isto é, o que quer que siga formalmente da natureza infinita de Deus segue objetivamente em Deus, da ideia de Deus, com a mesma ordem e a mesma conexão" ${ }^{\text {,4 }}$, não deixa dúvidas de que os atributos de Deus precisam estar "organizados" segundo uma mesma ordem e uma mesma conexão, pois só assim tudo aquilo que segue "formalmente da natureza de Deus", isto é, de "sua potência atual de agir" (as coisas singulares que seguem da necessidade de sua potência), também poderão seguir "objetivamente da ideia Deus", isto é, de "sua potência de pensar" (as ideias dos pensamentos singulares que seguem de sua natureza essencial). Esse corolário possui grande destaque no percurso dedutivo da Ética porque ele é um dos principais elementos da fundamentação conceitual que permitirá a Spinoza deduzir, mais adiante, grande parte das questões que dizem respeito à relação mente-corpo de sua filosofia. Um bom exemplo disso é a primeira proposição, da Parte V. Mesmo situada bem mais adiante na obra, na última parte da Ética para ser exato, Spinoza, após afirmar que "os pensamentos e as ideias das coisas são ordenados e concatenados na mente, da mesma maneira que as afecções do corpo ou imagens das coisas são ordenados e concatenados no corpo"49, irá invocar justamente o corolário da sétima proposição, da Parte II, na demonstração da referida proposição, na Parte V.

Além disso, também não podemos deixar de notar que a demonstração da sétima proposição da Parte II, ainda que breve, reforça o enunciado com uma referência que também é muito importante. Trata-se do axioma 4, da Parte I: “O conhecimento do efeito depende do conhecimento da causa e o envolve." Por força de sua síntese, esse axioma indica que a ordenação e a conexão entre as ideias e as coisas, encontrará na dinâmica da relação de causa e efeito, sua principal propriedade. Disso segue que, em primeiro lugar, é preciso observar que a ordenação do conhecimento no interior da relação de causa e efeito, tal como indicado pelo axioma 4 da Parte I, refere-se a uma ordenação muito específica, em que "o conhecimento do efeito depende do conhecimento da

\footnotetext{
${ }^{48}$ SPINOZA, B. de. Ética, Parte II, Proposição VII, Corolário, p. 135.

${ }^{49}$ Ibid., Parte V, Proposição I, p. 525.
} 
causa e o envolve." Isso significa que a busca pelo conhecimento da causa é uma ação "demandada" pela mente quando esta se encontra disposta a querer conhecer a causa de um determinado efeito "percebido" por ela. Desse modo, aquilo que faz com que a mente se determine pela busca do conhecimento da causa de suas afecções, nada mais é do que sua "vontade" (falaremos mais sobre as volições da mente no segundo capítulo) de querer conhecer os efeitos que ela ignora acerca de suas afecções. Isto é, aquilo que a mente concebe inicialmente - enquanto efeitos da ação das afecções - que desperta na mente sua disposição em querer buscar o conhecimento da causa, nada mais é do que as "sensações" (ideias confusas) que a mente produz a partir da só "percepção" dos efeitos causados pela potência das "afecções". A presença do axioma 4 (da Parte I) na sétima proposição da Parte II, não deixa dúvidas de que, na mente, a ordenação e a conexão das ideias e das coisas envolvem, tanto o conhecimento das causas, quanto o conhecimento dos efeitos das coisas que são objetos de suas ideias. Daí o final do enunciado afirmar que se trata de uma ação de "envolvimento". Isso significa que a ordenação e a conexão das coisas são conhecidas pela mente, na mesma medida em que a mente também conhece a ordenação e conexão das ideias. Ao fim do processo, ambas as ordenações e conexões convergem a um só e mesmo conhecimento acerca de tudo aquilo em que a mente se encontra envolvida. $\mathrm{O}$ que a mente produz como ordenação e conexão, são as ideias concebidas a partir do conhecimento da ordenação e conexão das coisas, enquanto organização das ideias de suas "afecções".

Conforme mencionado anteriormente, tanto o enunciado da sétima proposição, quanto sua demonstração e corolário, são extremamente breves, cabendo ao seu escólio a função de apresentar uma explicação mais detalhada sobre seu significado. Como a proposição se refere à natureza essencial da mente e de sua potência de pensar, essa espécie de "mediação" exercida pela relação de causa e efeito na efetividade da equiparação entre a ordem e a conexão das ideias e a ordem e a conexão das coisas, certamente diz respeito a uma propriedade da natureza de Deus. Na verdade, trata-se de mais uma demonstração da unidade da substância, pois, conforme esclarece a primeira parte do escólio, 
o que quer que possa ser percebido pelo intelecto infinito como constituindo a essência da substância pertence apenas à substância única e, por conseguinte, a substância pensante e a substância extensa são uma só e a mesma substância, compreendida ora sob este, ora sob aquele atributo. Assim também um modo da extensão e a ideia desse modo são uma só e a mesma coisa, expressa todavia de duas maneiras. ${ }^{50}$

Com efeito, contrariamente ao que afirma a ontologia cartesiana, a substância pensante e a substância extensa não são substâncias separadas e distintas, mas "são uma só e mesma substância, compreendida ora sob este, ora sob aquele atributo." Nesse sentido, a sétima proposição se consolida como um dos momentos mais importantes da Ética, pois se refere à ocasião em que Spinoza deduz que a natureza humana não é constituída por duas substâncias distintas como acreditava Descartes, mas por uma única e mesma substância que é compreendida, ora sob o atributo pensamento, ora sob o atributo extensão (trata-se do segundo momento que marca o distanciamento da ontologia cartesiana. O primeiro, conforme vimos anteriormente, havia sido a ruptura com o modelo que separa a mente de Deus)

Uma vez reafirmada - na primeira parte do escólio - a unidade da substância e sua potência de poder ser concebida, ora sob o atributo pensamento, ora sob o atributo extensão ${ }^{51}$, a segunda parte é dedicada a demonstrar de que maneira ocorre a equiparação entre os dois atributos e também como a substância única pode ser compreendida, ora sob um atributo, ora sob outro.

Por exemplo, um círculo existente na natureza e a ideia do círculo existente, que também está em Deus, são uma só e a mesma ideia, que é explicada por atributos diversos; e portanto, quer concebamos a natureza sob o atributo Extensão, quer sob o atributo Pensamento, quer sob outro qualquer, encontraremos uma só e a mesma ordem, ou seja, uma só e a mesma conexão de causas, isto é, as mesmas coisas seguirem umas das outras. E por isso, quando eu disse que Deus é causa de uma ideia, da de círculo por exemplo, apenas enquanto é coisa pensante, e do círculo apenas enquanto é coisa extensa, não foi senão porque o ser formal da ideia de círculo só pode ser percebido por outro modo de pensar, como causa próxima, e este, por sua vez, por outro, e assim ao infinito, de tal maneira que, enquanto as coisas são consideradas como modos de pensar, devemos explicar a ordem da natureza inteira, ou seja, a conexão das causas, pelo só atributo

\footnotetext{
${ }^{50}$ SPINOZA, B. de. Ética, Parte II, Proposição VII, Escólio, p. 137.

${ }^{51}$ Spinoza já havia demonstrado - na proposição 14, da Parte I - que "na natureza das coisas não é dada senão uma substância" (corolário 1) e "que a coisa extensa e a coisa pensante são ou atributos de Deus ou afecções dos atributos de Deus" (corolário 2).
} 
Pensamento, e enquanto são consideradas como modos da Extensão, também a ordem da natureza inteira deve ser explicada pelo só atributo Extensão; e entendo o mesmo quanto aos outros atributos. ${ }^{52}$

Por fim, sobre a questão da sétima proposição se referir ou não a um paralelismo, vejamos o que as considerações apresentadas pelo próprio Spinoza nos permitem concluir. A primeira parte do escólio não deixa dúvidas de que os modos singulares não são constituídos por duas substâncias distintas, mas por uma única substância que, entre seus infinitos atributos, possui dois que podem ser concebidos pela mente: o pensamento e a extensão. No entanto, a mente os concebe de maneira independente, ora sob os efeitos de um, ora sob os efeitos de outro, estabelecendo-se, assim, uma equiparação entre suas potências no interior dos modos certos e determinados da substância, em que ambos expressam a essência infinita de Deus, ora sob um atributo, ora sob outro. Sendo assim, a relação de equiparação entre a potência dos atributos pensamento e extensão - tal como sugere Chaui - se justifica porque ambos são expressões da substância. Essa equivalência seguirá, portanto, da necessidade da própria substância, à medida que ela se expressa em seus modos singulares e essa necessidade atua como garantia da igualdade entre a ordem e a conexão das ideias e a ordem e a conexão das coisas, que, por sua vez, atuam como condição necessária da simultaneidade dos dois atributos na mente humana, permitindo que possam ser concebidos, ora como ideias do atributo pensamento, ora como ideias do atributo extensão. É importante notar que não se trata de um paralelismo entre pensamento e extensão, pois, se assim o fosse, teríamos que concebê-los como realidades distintas, o que sabemos não ser o caso.

Pensamento e extensão são atributos de uma mesma e única substância, o que indica se tratar dos atributos de uma única e mesma existência, cuja realidade pode ser concebida pela mente de duas maneiras diferentes, contudo de maneira simultânea. São maneiras diferentes de conceber a atualidade do "ser das coisas", porém expressas numa única e mesma existência, num único e mesmo modo singular. O que existe de fato é uma variação de atributos na consolidação da realidade das coisas que são concebidas pelas ideias da mente, pois, tal como afirma Spinoza - na nona proposição, da Parte I - "quanto mais

${ }^{52}$ SPINOZA, B. de. Ética, Parte II, Proposição VII, Escólio, p. 137. 
realidade ou ser cada coisa tem, tanto mais atributos lhe competem. ${ }^{, 53}$ Ou seja, quanto mais atributos uma ideia tiver, "mais realidade ou ser" a coisa terá. Por isso, a qualidade do conhecimento acerca das coisas que pertencem ao "ser da substância”, irá depender da intensidade de sua existência na realidade das coisas, isto é, irá depender da quantidade de atributos que lhe competem. Conhecer as coisas que seguem da essência de Deus, significa conhecer seus atributos. Por isso, quanto mais atributos da substância conhecemos, mais conhecemos a realidade de sua existência eterna e infinita. $\mathrm{O}$ atributo pensamento e o atributo extensão não constituem realidades paralelas do "ser da substância”, tanto é que ambos podem ser concebidos da mesma maneira: "A ordem e a conexão das ideias é a mesma que a ordem e conexão das coisas”. Os dois atributos, em conjunto, constituem com a mesma potência de ser e de existir, tudo que diz respeito à realidade do "ser formal" das coisas concebidas pela mente humana, assim como de suas modificações, que seguem da necessidade da natureza divina, sempre com a mesma ordem e a mesma conexão.

\subsection{2. \\ O ser formal das coisas singulares e a origem do modo humano}

Após deduzir a mente a partir dos atributos pensamento e extensão, assim como da estrutura de equiparação entre a ordenação e a conexão das ideias e das coisas, Spinoza, então, segue para a dedução das propriedades da mente que estão mais diretamente relacionadas ao modo humano de existência. Isso não significa que nas proposições anteriores a natureza do homem não estivesse envolvida, muito pelo contrário. A mente humana - conforme foi amplamente demonstrado nas proposições iniciais - é parte do intelecto divino e dele jamais se separa. A diferença é que nas primeiras proposições, a dedução da natureza essencial da mente se refere às propriedades do que segue do "ser da substância”, e o que veremos nas próximas proposições é a dedução das propriedades em relação ao "ser formal" das coisas singulares, que são as ideias que a mente humana concebe dos atributos pensamento e extensão.

${ }^{53}$ SPINOZA, B. de. Ética, Parte I, Proposição IX, p. 57. 
Spinoza inicia a dedução anunciando - na décima proposição - que "à essência do homem não pertence o ser da substância, ou seja, a substância não constitui a forma do homem". 54 Aparentemente, "a forma do homem", tal como sugere a proposição, parece indicar mais a sua negação em relação ao "ser da substância", do que sua afirmação como modo humano de existência. Porém, há um detalhe importante a ser considerado.

Como o conceito de forma é empregado por Espinosa no sentido de essência e natureza determinada, "forma do homem" aparece aqui com um escopo claro, isto é, criticar diretamente a noção escolástica de forma substancial - "uma substância não constitui a forma do homem" - e, indiretamente, a suposição cartesiana da essência do homem como substância criada. ${ }^{55}$

No que diz respeito ao modo humano de existência, o "conceito de forma no sentido de essência", tal como utilizado por Spinoza, é importante principalmente porque ele nos permite entender que a "forma do homem", isto é, a "essência do homem", não é justificada através do conceito de substância. Além disso, o "conceito de forma no sentido de essência" garante a integridade da substância única e de sua indivisibilidade ("à essência do homem não pertence o ser da substância"). Além disso, o conceito de "forma do homem", não pertencendo ao ser da substância, permitirá a Spinoza deduzir, mais adiante - na terceira parte da Ética - que o homem terá como essência o conatus (enquanto esforço atual para perseverar em seu ser) e o desejo (enquanto determinação de sua ação, em resposta a uma afecção qualquer). Ou seja, a essência do homem, isto é, "sua forma", não segue da necessidade de uma determinação substancial que estabelece sua existência como uma de suas propriedades, nem tampouco que a essência do homem é determinada pela ação de outras substâncias “criadas" a partir da substância única. Conforme afirma Spinoza no corolário da décima proposição, "a essência do homem é constituída por modificações certas dos atributos de Deus." ${ }^{, 56}$ Sendo assim, a forma do homem, isto é, sua essência, será determinada pela dinâmica que envolve as modificações dos atributos de Deus. Ora, se por "modificações dos atributos" devemos entender as ideias que a mente produz acerca de como ela é afetada

\footnotetext{
${ }^{54}$ SPINOZA, B. de. Ética, Parte II, Proposição X, p. 141.

${ }_{55}$ CHAUI, M. A nervura do real II: imanência e liberdade em Espinosa, p. 138.

${ }^{56}$ SPINOZA, B. de, op. cit., Parte II, Proposição X, Corolário, p. 143.
} 
pelas modificações dos modos certos e determinados de Deus, ou seja, pelas modificações da realidade desses modos, isso significa que a dinâmica que é responsável pela essência do homem também envolverá a natureza de tudo que segue dessas modificações.

É preciso entender que, no caso da mente humana, as modificações dos modos certos e determinados de Deus são estabelecidas a partir das "coisas" que são "percebidas" pela mente, enquanto esta se encontra afetada pelas ideias de tais percepções. Sabemos que essas "coisas" se referem às afecções do corpo e as ideias se referem ao reconhecimento da existência desse corpo em ato (abordaremos essa questão com maiores detalhes no segundo capítulo de nosso estudo, quando investigaremos a dedução do corpo e dos gêneros de conhecimento). No momento, basta esclarecer que o "ser formal" que constitui a essência do homem, isto é, a "forma do homem", não poderá ser estabelecido pelos atributos de uma natureza substancial, tal como acontece na ontologia cartesiana, em que a mente é concebida como substância.

Porém, ainda que as ideias produzidas pela mente humana não pertençam ao ser da substância, isso não significa que elas estão separadas do intelecto divino, muito menos que estão fora dele, pois, como afirma Spinoza - na nona proposição, também da Parte II - “A ideia de uma coisa singular existente em ato tem como causa Deus não enquanto é infinito, mas enquanto considerado afetado por outra ideia de coisa singular existente em ato, cuja causa também é Deus enquanto afetado por uma terceira, e assim ao infinito. ${ }^{, 57}$ Sendo assim, as ideias das coisas singulares existentes em ato que são concebidas pela mente humana, terão Deus como causa, porém não enquanto substância infinita, mas enquanto ideais dos atributos das afecções de outra coisa singular, igualmente existente em ato, que também tem Deus como causa "e assim ao infinito". Isso pode provocar uma série de implicações, como, por exemplo, a conclusão de que, nessa perspectiva, só podemos conhecer as ideias de uma coisa singular existente em ato, à medida que somos afetado pelas ideias de uma outra coisa singular igualmente existente em ato, e assim ao infinito.

Uma vez deduzida a natureza da mente a partir da equiparação entre a potência dos atributos pensamento e extensão, será preciso agora investigar os

${ }^{57}$ SPINOZA, B. de. Ética, Parte II, Proposição IX, p. 139-141. 
desdobramentos da equiparação dessa potência no modo humano de existência. Levando-se em conta que o corolário da décima proposição considera que "a essência do homem é constituída por modificações certas dos atributos de Deus", será preciso, então, identificar a origem que permitirá conhecer a causa dessas modificações, isto é, será preciso conhecer o corpo. Antes, porém, Spinoza nos oferece duas proposições que atuam como uma introdução ao tema. Trata-se das proposições 11 e 12. A décima primeira proposição se encarrega de estabelecer que "o que primeiramente constitui o ser atual da mente humana é nada outro que a ideia de uma coisa singular existente em ato." ${ }^{, 58} \mathrm{Na}$ décima segunda proposição, Spinoza afirma que “[...] se o objeto da ideia que constitui a mente humana for corpo, nada poderá acontecer nesse corpo que não seja percebido pela mente. ${ }^{, 59}$ Com isso, Spinoza passa, então, a uma nova etapa de sua dedução da mente, agora a partir do objeto da ideia que a constitui, isto é, o corpo, que será o tema do próximo capítulo desta dissertação.

Assim, podemos observar que Spinoza, nas primeiras proposições da Parte II, inicia sua demonstração da natureza humana a partir de uma mudança na ordem de como a própria Natureza é demonstrada, passando da natureza naturante do "ser da substância", para a natureza naturada das "coisas singulares". Nesse sentido, vimos como esse simples movimento permitiu a Spinoza "transitar" de um aspecto ontológico para outro, sem, contudo, abrir mão de sua doutrina da substância única, isto é, sem precisar recorrer a mudanças de ordem substancial. O pensamento e a extensão são atributos de Deus, afirma Spinoza já nas primeiras proposições da segunda parte, mas também é aquilo que permite ao homem "conhecer" sua própria realidade e tudo que ela envolve, por meio dos corpos e modos de pensar, tal como atesta o quinto axioma, também da Parte II. Uma só e mesma substância constitui a natureza essencial do "ser da substância", assim como também do "ser formal" dos modos singulares, e isso porque, como nos ensinou Spinoza - na sétima proposição - uma só e a mesma é a ordem e a conexão das ideias e das coisas. A natureza divina e a natureza das coisas singulares, portanto, pertencem a uma mesma e única substância. Por isso, Spinoza se refere à mente humana como

\footnotetext{
${ }^{58}$ SPINOZA, B. de. Ética, Parte II, Proposição XI, p. 147.

${ }^{59}$ Ibid., Parte II, Proposição XII, p. 147.
} 
uma das coisas "que deve seguir necessariamente da essência de Deus" e, por isso, os pensamentos singulares também devem seguir necessariamente do intelecto divino, por meio dos atributos pensamento e extensão, que é a grande questão demonstrada por Spinoza até esse momento de sua dedução da mente e da natureza humana. 


\section{3 \\ O objeto da ideia que constitui a mente humana: o corpo} Daí segue que o homem consta de Mente e Corpo, e que o Corpo humano existe tal como
o sentimos.

Spinoza

Motivo de intensos debates entre comentadores e pesquisadores de maneira geral, a concepção spinozista de corpo é um dos temas mais estudados da filosofia de Spinoza. Porém, é curioso observar que Spinoza parte de uma única proposição para apresentar sua dedução de corpo. Trata-se da décima terceira proposição da Parte II. Ainda que esta proposição seja seguida de demonstração, corolário e escólio, Spinoza optou por também utilizar uma pequena estrutura (que ficou conhecida como "pequena física") para estabelecer as propriedades da natureza do que ele mesmo afirmar ser - no escólio da proposição - "nosso corpo". Essa "divisão" existente entre os elementos da proposição e a estrutura da "pequena física" é bastante significativa porque ela indica uma distinção de ordem conceitual que é importante, tanto para a integridade do método dedutivo da ordem geométrica, quanto para a dinâmica que o corpo adquire na concepção spinozista.

No caso do enunciado da décima terceira proposição e de seus respectivos elementos complementares (demonstração, corolário e escólio), não devemos esquecer que, por se tratar de uma proposição da Parte II, isso significa que continuamos falando do "que deve seguir necessariamente da essência de Deus." Dessa maneira, apesar de se referirem à origem do corpo e da constituição de sua natureza, ainda assim, se trata de algo que está relacionado à natureza da mente, como sendo uma de suas propriedades. Daí o enunciado da décima terceira proposição afirmar que "O objeto da ideia que constitui a mente humana é o corpo, ou seja, um modo certo da extensão, existente em ato, e nada outro". ${ }^{61}$ No entanto, como Spinoza reafirma sua definição de corpo (primeira definição da Parte II) na segunda metade do enunciado: “[...] um modo certo da extensão, existente em ato, e nada outro", a "pequena física" apresentada após o escólio torna-se necessária porque, como se trata de "um modo certo da extensão", será preciso, portanto, deduzir as propriedades da natureza daquilo

\footnotetext{
${ }^{60}$ SPINOZA, B. de. Ética, Parte II, Proposição XIII, Corolário, p. 149.

${ }^{61}$ Ibid., Proposição XIII, p.149.
} 
que constitui o objeto ao qual o "modo certo da extensão" se refere, ou seja, será preciso deduzir as propriedades do corpo.

Com efeito, se o enunciado da décima terceira proposição e de seus respectivos elementos complementares se referem à natureza dos corpos em geral, a "pequena física" irá se referir às propriedades que seguem dessa natureza, permitindo deduzir o corpo enquanto objeto de um "modo certo da extensão, existente em ato". Daí grande parte do conteúdo da "pequena física" ser deduzido através de axiomas, lemas e postulados e, obviamente, daí essa estrutura ser chamada de "pequena física". Porém, antes de seguir adiante, é preciso esclarecer duas questões. Em primeiro lugar, a referida existência de uma "distinção de ordem conceitual” que foi citada acima, não se refere, em hipótese alguma, a uma dedução que concebe o corpo separando sua natureza essencial de suas propriedades. O que está sendo sugerido aqui é que a décima terceira proposição deduz inicialmente a natureza essencial do corpo, para depois deduzir suas propriedades, na "pequena física". Em segundo lugar, dada a importância que esta proposição representa para o estudo dos afetos - que é o tema do terceiro e último capítulo deste estudo - mesmo mantendo a proposta de apresentar apenas uma abordagem resumida das questões a serem investigadas, iremos dedicar atenção especial à dedução spinozista de corpo, pois, uma vez afirmado - no axioma 4, da Parte II - que "sentimos um corpo ser afetado de muitas maneiras", Spinoza deixa claro que será através do corpo que a mente sentirá os afetos. Além disso, se no quarto axioma da primeira parte também aprendemos que "o conhecimento do efeito depende do conhecimento da causa e o envolve", veremos que esse "efeito" que a mente irá conhecer através do conhecimento da causa se refere exatamente ao afeto que é sentido pelo corpo.

\section{1 .}

\section{A natureza dos corpos em geral}

Com efeito, ninguém até aqui determinou o que o Corpo pode [...]. ${ }^{62}$

${ }^{62}$ SPINOZA, B. de. Ética, Parte III, Proposição II, Escólio, p. 243. 
Conforme destacado anteriormente, sabemos que Spinoza inicia a dedução do corpo ainda no final da proposição anterior (décima segunda proposição), ao concluir que "[...] se o objeto da ideia que constitui a mente humana for corpo, nada poderá acontecer nesse corpo que não seja percebido pela mente."63 Porém, é a partir da décima terceira proposição que Spinoza irá apresentar uma dedução mais objetiva de corpo e é na demonstração da proposição que encontraremos a indicação de que se trata de uma relação imediata entre as afecções do corpo e suas ideias concebidas pela mente. Na demonstração, Spinoza reivindica o axioma 4, da Parte II - "Sentimos um corpo ser afetado de muitas maneiras" - para enfim justificar que "[...] o objeto da ideia que constitui a mente humana é o corpo, e este é existente em ato." ${ }^{\text {64 }}$ Com base nisso, Spinoza conclui, no corolário, “[...] que o homem consta de mente e corpo, e que o corpo humano existe tal como o sentimos." ${ }^{, 65}$ A partir das duas deduções, Spinoza abre o escólio da décima terceira proposição afirmando que "disso não somente entendemos que a mente é unida ao corpo, mas também o que se há de entender por união da mente e do corpo."

Com efeito, a partir do final da décima segunda proposição, incluindo o enunciado da décima terceira e considerando o conteúdo demonstrativo de seus elementos complementares, é possível concluir que o corpo é deduzido por Spinoza, na proposição 13 , como algo cuja própria natureza é estar unido à mente. Isto é, a união da mente com o corpo é deduzida de maneira imediata, no mesmo enunciado que deduz o corpo, na décima terceira proposição. Daí a primeira parte do referido trecho do escólio afirmar que "disso entendemos que a mente é unida ao corpo".

Em outras palavras, se não compreendermos o que significa definir a mente humana como ideia de seu corpo seremos levados a supor, à maneira platônica, que a mente é uma alma que dirige o corpo, como piloto dirige o navio; ou à maneira aristotélica, que ela é o princípio da vida do corpo e de suas diferentes funções e ele, seu instrumento ou órganon; ou, enfim, à maneira cartesiana, que ela é uma substância unida a uma outra de natureza diversa da sua e, visto o corpo ser, cartesianamente, um maquinismo ou composição de partes extra partes enquanto a alma é espiritualmente pensante, não se entende, afinal, porque o homem é composto de ambos, uma vez que cada um deles pode e deve ser

\footnotetext{
${ }^{63}$ SPINOZA, B. de. Ética, Parte II, Proposição XII, p. 147.

${ }^{64}$ Ibid., Parte II, Proposição XIII, Demonstração, p. 149.

${ }^{65}$ Ibid., Parte II, Proposição XIII, Corolário, p. 149.

${ }^{66}$ Ibid., Parte II, Proposição XIII, Escólio, p. 149.
} 
tomado sem qualquer relação com o outro e por isso sua união só pode ser uma ideia obscura e confusa cuja explicação encontra-se no asylum ignoratiae, isto é, na vontade insondável de Deus. ${ }^{67}$

Ainda que a concepção spinozista de corpo de fato se contraponha às concepções platônica e aristotélica, não podemos deixar de considerar que sua repercussão ganha ainda mais destaque quando se trata de ser mais um dos momentos em que o pensamento de Spinoza se distancia da ontologia cartesiana. Se antes a filosofia spinozista havia estabelecido sua ruptura com o pensamento de Descartes - primeiro por rejeitar a separação entre Deus e mente e, posteriormente, por negar a natureza humana como sendo constituída por duas substâncias distintas - agora, ao deduzir a mente humana como ideia de seu corpo, observamos o pensamento de Spinoza recusar totalmente a noção cartesiana de uma substância unida a uma outra de natureza completamente distinta. Dessa maneira, a mente humana como ideia de seu corpo, não se refere a uma união entre duas substâncias, mas entre modos finitos dos atributos de uma única substância.

É da natureza do corpo e da natureza de sua ideia serem coisas singulares (isto é, conforme a definição de coisa singular, causa única de seus múltiplos efeitos), mas a singularidade de cada um deles não é causada por uma ação de um deles sobre o outro (pois não há ação causal entre modos de atributos diferentes) e sim pela ação de seus respectivos atributos. ${ }^{68}$

Por não se tratar de uma união entre substâncias distintas, a singularidade do corpo, assim como a singularidade de sua ideia na mente de quem o concebe, se unem enquanto modos diferentes de uma mesma e única substância, assim como também se constituem num mesmo e único modo singular, simultaneamente. Contudo, conforme sugere o axioma 4, da Parte II, como "sentimos um corpo ser afetado de muitas maneiras", isso significa que os modos singulares também são igualmente afetados de muitas maneiras, e tal como indica o quinto axioma, também da Parte II, "não sentimos nem percebemos nenhuma coisa singular além de corpos e modos de pensar", isso

\footnotetext{
${ }^{67}$ CHAUI, M. A nervura do real II: imanência e liberdade em Espinosa, p. 153.

${ }^{68}$ Ibid., p. 152.
} 
significa que conhecemos as coisas singulares à medida que sentimos as afecções do corpo e as ideias que a mente concebe dessas afecções.

Contudo [afirma Spinoza no escólio da décima terceira proposição], digo de maneira geral que quanto mais um corpo é mais apto do que outros para fazer [agir] ou padecer muitas coisas simultaneamente, tanto mais a sua mente é mais apta do que outras para perceber muitas coisas simultaneamente; e quanto mais as ações de um corpo dependem somente dele próprio, e quanto menos outros corpos concorrem com ele para agir, tanto mais apta é a sua mente para entender distintamente. $\mathrm{E}$ a partir disto podemos conhecer a superioridade de uma mente diante das outras ${ }^{69}$; podemos, ademais, ver o motivo por que não temos senão um conhecimento bastante confuso de nosso corpo. ${ }^{70}$

Nesse sentido, como "quanto mais um corpo é mais apto do que outros para agir ou padecer muitas coisas simultaneamente" e como de "nosso corpo não temos senão um conhecimento bastante confuso", "nos é necessário [afirma Spinoza no mesmo escólio], conhecer a natureza do seu objeto, isto é, o corpo humano".

Contudo, a segunda parte do escólio da décima terceira proposição levanta uma importante questão. Se podemos entender que o corpo é deduzido como algo que já se encontra unido à mente, então qual seria o significado da afirmação: “[...] mas também o que se há de entender por união da mente e do corpo"? Antes mesmo de oferecer uma resposta, Spinoza antecipa: "Na verdade, ninguém a poderá entender adequadamente [união da mente e do corpo], ou seja, distintamente, se primeiro não conhecer a natureza do nosso corpo adequadamente." ${ }^{71}$ Portanto, a união da mente com o corpo pode até ser concebida diretamente, a partir da só dedução do enunciado da décima terceira proposição e de seus elementos complementares, porém, para conhecer essa união adequadamente, será preciso ir além, até porque, conforme o próprio Spinoza adverte, todas as questões demonstradas até agora sobre a natureza do corpo não dizem respeito apenas ao corpo humano, mas se referem aos corpos em geral "e, por consequência, tudo o que dissemos da ideia do corpo humano

\footnotetext{
69 "Superioridade de uma mente diante das outras" aqui se refere ao fato do objeto da ideia de uma mente conter "mais realidade" que o objeto da ideia de outra, ou seja, conter mais afeç̧ões: "tampouco podemos negar que as ideias diferem entre si tal como os próprios objetos, e que uma é superior e contenha mais realidade do que outra, conforme o objeto de uma seja superior e contenha mais realidade do que o objeto da outra." SPINOZA, B. de. Ética, Parte II, Proposição XIII, Escólio, p. 149-151

${ }^{70}$ Ibid., Parte II, Proposição XIII, Escólio, p. 151.

${ }^{71}$ Ibid., Parte II, Proposição XIII, Escólio, p. 149.
} 
há de dizer-se necessariamente da ideia de uma coisa qualquer". ${ }^{72}$ Isso significa que o corpo que Spinoza afirma ser o "objeto da ideia que constitui a mente humana", não se refere exclusivamente ao corpo humano, mas ao corpo de "uma coisa qualquer", isto é, aos corpos de maneira geral.

Sendo assim, conforme sugere o próprio Spinoza, para entender corretamente a união da mente com o corpo, será preciso conhecer primeiro "a natureza do nosso corpo adequadamente", o que só acontece, de fato, ao longo da "pequena física" que é apresentada imediatamente após o escólio.

\subsection{1.}

\section{A primeira parte da pequena física e a natureza dos corpos simples}

As propriedades da natureza do corpo humano, conforme já destacado anteriormente, são descritas na "pequena física" que segue após o escólio da décima terceira proposição, da Parte II. Trata-se de uma estrutura formada por cinco axiomas, sete lemas, uma definição e, por fim, um conjunto de seis postulados. A estrutura encontra-se dividida em duas partes, sendo a primeira formada pelos quatro axiomas iniciais e os três primeiros lemas; enquanto a segunda parte é composta pela definição, um axioma, os quatro lemas restantes e o conjunto de seis postulados. Segundo o próprio Spinoza, a primeira parte da estrutura se refere à dedução dos corpos "simplíssimos, a saber, os que se distinguem uns dos outros só por movimento e repouso, por rapidez e lentidão" ${ }^{73}$, enquanto a segunda parte é dedicada à dedução dos corpos "compostos". A partir de um resumo de toda a estrutura, é possível constatar que não estamos diante de um tratado de física, tal como o Le monde, de Descartes ou o De corpore, de Hobbes. Entre os diversos significados que isso pode indicar, iremos comentar apenas alguns aspectos que podem ser considerados como os mais significativos para os interesses específicos deste estudo, isto é, aqueles que dizem respeito à vida cognitiva e à vida afetiva.

O primeiro deles é indicado pelo lema 1, pois, ao afirmar que "os corpos se distinguem uns dos outros em razão do movimento e do repouso, da rapidez e

\footnotetext{
${ }^{72}$ SPINOZA, B. de. Ética, Parte II, Proposição XIII, Escólio, p. 149.

${ }^{73}$ Ibid., Parte II, Proposição XIII, Axioma II (após o Lema III), p. 155.
} 
da lentidão, e não em razão da substância"74, torna-se evidente que os corpos, ainda que em nenhum momento deixam de ser "expressões" da essência de Deus em modos certos e determinados da extensão, não se distinguem uns dos outros em razão do ser da substância, mas em razão das afecções que afirmam a "atualidade" da existência desses corpos, isto é, em razão do "estado" atual em que este ou aquele corpo se encontra na atualidade (movimento ou repouso rapidez ou lentidão). Mais adiante, o lema 3 estabelece que as modificações da atualidade de um corpo serão determinadas pela ação de outro corpo, cuja atualidade também foi modificada por outro e assim ao infinito. "Daí segue que um corpo em movimento continua a mover-se até que seja determinado por outro a repousar; e um corpo em repouso também continua a repousar até que seja determinado por outro ao movimento. ${ }^{, 75}$ Por fim, dois axiomas concluem a primeira parte da "pequena física". Neles, Spinoza deduz, em primeiro lugar, que todas

as maneiras como um corpo é afetado por outro corpo seguem da natureza do corpo afetado e simultaneamente da natureza do corpo afetante; de tal maneira que um só e o mesmo corpo é movido diferentemente conforme a diversidade de natureza dos corpos moventes, e inversamente, corpos diversos são movidos diferentemente por um só e o mesmo corpo. ${ }^{76}$

$\mathrm{Na}$ sequência, o segundo axioma afirma que "quando um corpo em movimento atinge outro em repouso e não pode demovê-lo, é refletido de tal maneira que continua a mover-se [...]". ${ }^{77}$ Segundo explicação do próprio Spinoza, essas propriedades dizem respeito apenas aos corpos simples, isto é, àqueles que se distinguem uns dos outros só pelo movimento e repouso; pela rapidez e lentidão. Nessa primeira parte, a natureza do corpo é deduzida a partir da física de um só corpo e de sua relação com outros corpos igualmente simples. Em seguida, veremos como essa dedução ocorre nos chamados "corpos compostos".

\footnotetext{
${ }^{74}$ SPINOZA, B. de. Ética, Parte II, Proposição XIII, Lema I, p. 151.

${ }^{75}$ Ibid., Parte II, Proposição XIII, Lema III, Corolário, p. 153.

${ }^{76}$ Ibid., Parte II, Proposição XIII, Corolário, Axioma I, p. 155.

${ }^{77}$ Ibid., Parte II, Proposição XIII, Escólio, Axioma II, p. 155.
} 


\subsection{2.}

\section{A segunda parte da pequena física e os corpos compostos}

Spinoza inicia a segunda parte da "pequena física" com uma definição ${ }^{78}$ que é um dos momentos mais importantes da concepção de corpo de sua filosofia.

Quando alguns corpos de mesma ou diversa grandeza são constrangidos por outros de tal maneira que aderem uns aos outros, ou se movem com o mesmo ou diverso grau de rapidez de tal maneira que comunicamos seus movimentos uns aos outros numa proporção certa, dizemos que esses corpos estão unidos uns aos outros e todos em simultâneo compõem um só corpo ou indivíduo, que se distingue dos outros por essa união de corpos. ${ }^{79}$

Além de ser fundamental para a dedução dos corpos compostos, um detalhe que podemos (e devemos) observar aqui, é que Spinoza utiliza a expressão "indivíduo" para se referir a uma singularidade múltipla, isto é, formada por uma união de corpos de origem diversa. Portanto, no spinozismo conforme indica a definição da "pequena física" - indivíduo deve ser considerado sinônimo de união de corpos, cujo resultado é a consolidação de um indivíduo múltiplo marcado pela intercorporeidade. Por isso, o tema se encontra presente em praticamente todos os momentos da segunda parte da "pequena física”. No axioma que segue à definição, por exemplo, Spinoza deduz que é a partir da quantidade de "partes de um indivíduo ou corpo composto" - que se unem umas às outras a partir de superfícies maiores ou menores - que será determinada a capacidade que esse "indivíduo ou corpo composto" terá de ser mais difícil ou facilmente coagido a ter que mudar ou não de configuração.

E por isso, chamarei duros aqueles corpos cujas partes aderem umas às outras segundo grandes superfícies; moles, aqueles cujas partes aderem umas às outras segundo pequenas superfícies; e, enfim, fluidos, aqueles cujas partes se movem umas por entre as outras. ${ }^{80}$

Nesse sentido, os lemas que seguem a partir desse axioma, irão tratar das diferentes variações com que a união de corpos de um indivíduo é deduzida na

\footnotetext{
${ }^{78}$ Trata-se da definição de corpos compostos. A definição de corpo, como vimos inicialmente, encontra-se na abertura da Parte II.

${ }^{79}$ SPINOZA, B. de. Ética, Parte II, Proposição XIII, Escólio, Definição, p. 155.

${ }^{80}$ Ibid., Parte II, Proposição XIII, Escólio, Axioma III, p. 157.
} 
"pequena física". São questões da natureza dos corpos compostos, tais como, por exemplo, dos corpos de um indivíduo que são substituídos por outros corpos de mesma natureza, não alterando a natureza do próprio indivíduo (lema 4); mudanças no tamanho das partes componentes de um indivíduo (aumento ou diminuição da quantidade de corpos), numa proporção tal que as partes, em conjunto, conseguem manter a mesma proporção de movimento e de repouso umas com as outras, de forma que a natureza do indivíduo é mantida sem alteração (lema 5), etc. No escólio que antecede o conjunto de seis postulados que encerra a "pequena física", Spinoza se dedica a explicar as razões pelas quais "um indivíduo composto pode ser afetado de várias maneiras, conservando contudo, a sua natureza" $"$, , assim como um "terceiro gênero de indivíduos" - composto de indivíduos desse "indivíduo composto" - podem igualmente ser afetados de muitas outras maneiras, porém também conservando a sua natureza. "E se continuarmos assim ao infinito, conceberemos facilmente que a natureza inteira é um indivíduo cujas partes, isto é, todos os corpos, variam de infinitas maneiras, sem nenhuma mudança do indivíduo inteiro." 82

\section{2 . \\ A relação mente-corpo e a origem da vida cognitiva}

Nem o Corpo pode determinar a Mente a pensar, nem a Mente pode determinar o Corpo ao movimento, ao repouso ou a alguma outra coisa (se isso existe). ${ }^{83}$

Spinoza

Após ter deduzido a natureza essencial da mente e a origem do corpo nas proposições iniciais da Parte II da Ética, a partir da décima quarta proposição, Spinoza inicia o longo percurso (são 36 proposições, muitas acompanhadas de demonstrações, corolários e escólios) que irá deduzir a estrutura demonstrativa da relação entre ambos os modos da substância. Como vimos desde os primeiros momentos da segunda parte, a mente humana, assim como o objeto da ideia que a constitui de modo certo e determinado, existindo em ato, ou seja, seu corpo, é "aquilo que deve seguir necessariamente da essência de Deus", assim como

\footnotetext{
${ }^{81}$ SPINOZA, B. de. Ética, Parte II, Proposição XIII, Lema VII, Escólio, p. 159.

${ }^{82}$ Ibid., p. 161.

${ }^{83}$ Ibid., Parte III, Proposição II, p. 241.
} 
também já sabemos que esse enunciado se refere à ontologia spinozista dos modos singulares.

Até agora, acompanhamos os passos iniciais dessa ontologia, em que as propriedades essenciais, tanto da mente, quanto do corpo, foram demonstradas de maneira independente. A partir da décima quarta proposição, no entanto, Spinoza dá início a uma nova etapa de sua dedução dos modos singulares, em que a mente e o corpo passam a ser investigados a partir das propriedades que seguem das operações de ambos os modos. Contudo, mediante os objetivos do recorte temático proposto por esse estudo, não será necessário acompanhar cada passo do percurso dedutivo da relação entre a mente e o corpo, tal como demonstrada ao longo das últimas 36 proposições da Parte II (e de seus respectivos elementos complementares). Desse conteúdo, iremos considerar apenas os aspectos que mais adiante serão importantes para o estudo da vida afetiva, na terceira parte.

\subsection{1.}

Breves considerações sobre a união da mente com o corpo na segunda parte da Ética

A Mente e o Corpo são uma só e mesma coisa que é concebida ora sob o atributo do
Pensamento, ora sob o da Extensão.
$\begin{aligned} & { }^{4} \\ & \text { Spinoza }\end{aligned}$

Conforme destacamos anteriormente, a concepção spinozista de união da mente com o corpo não se refere a uma união de ordem substancial. Diferentemente do que acontece no caso da ontologia dualista, em que a mente e o corpo são concebidos como substâncias distintas, no monismo da filosofia de Spinoza a mente e o corpo são entendidos como modificações de uma mesma e única substância. Dada essa diferença de natureza ontológica, é evidente que na doutrina spinozista da substância única, a união da mente com o corpo também irá operar de maneira diferente. Daí o próprio Spinoza destacar - como vimos no escólio da décima terceira proposição - que "disso não somente entendemos que a mente é unida ao corpo [referindo-se ao enunciado da proposição], mas

${ }^{84}$ SPINOZA, B. de. Ética, Parte III, Proposição II, Escólio, p. 241. 
também o que se há de entender adequadamente, ou seja, distintamente, se primeiro não conhecer a natureza do nosso corpo adequadamente." ${ }^{\text {} 85}$

Em primeiro lugar, é importante destacar que, devido ao monismo da ontologia spinozista, assim como a organização geométrica do método dedutivo da Ética, isso desobriga Spinoza a ter que apresentar, inicialmente, uma teoria que justifique as condições necessárias para que ocorra a união da mente com o corpo, para então explicar de que maneira e em que circunstâncias essa união acontece. Conforme foi igualmente destacado anteriormente, ao deduzir o corpo, na décima terceira proposição da Parte II, Spinoza já o concebe unido à mente, de maneira imediata. Ao contrário de Descartes que, mediante as dificuldades para conseguir explicar como e em que circunstâncias a res cogitans consegue ser causa das determinações das ações da res extensa, precisou escrever um tratado específico sobre o tema e formular uma teoria justificando que essa união ocorre por meio de uma glândula no cérebro. Spinoza, por sua vez, não precisou formular uma teoria para justificar sua atitude em deduzir o corpo unido à mente, de maneira imediata, porque, uma vez se tratando de modificações de uma única e mesma substância, a união entre ambos se consolida à medida que eles expressam a essência de Deus em seus modos finitos. Daí o fato da décima terceira proposição não necessitar de uma estrutura argumentativa que justifique a natureza e a origem da união entre a mente e o corpo, e simplesmente afirmar que "o objeto da ideia que constitui a mente humana é o corpo".

Sendo assim, é preciso levar em consideração o fato de que o conjunto de proposições da segunda metade da Parte II não se referem, necessariamente, a uma estrutura que estabelece a união da mente com o corpo. Isso, como acabamos de ver, é feito de maneira imediata pelo próprio enunciado da décima terceira proposição e explicado mais detalhadamente em seus elementos complementares, ou seja, em sua demonstração, corolário e escólio, assim como também pela estrutura da "pequena física" que segue imediatamente após a proposição. Com efeito, a sequência de proposições que abordam a questão da união da mente com o corpo, na segunda metade da Parte II, na verdade se refere a uma demonstração da ordem como essa união acontece e as

${ }^{85}$ SPINOZA, B. de. Ética, Parte II, Proposição XIII, Escólio, p. 149. 
circunstâncias que envolvem a natureza dessa união. A dinâmica existente entre os dois modos, tal como demonstrada a partir da décima quarta proposição, "é o ponto de partida necessário na exposição da natureza da mente" ${ }^{\text {"86 }}$.

Por isso, efetuando um percurso inverso ao realizado com respeito ao corpo, Espinosa começa demonstrando (da proposição 16 à proposição 19) as formas e consequências da união do corpo e da mente enquanto esta percebe as afecções corporais e apenas depois disso se volta para o que segue da natureza da própria mente enquanto modo de pensamento. ${ }^{87}$

No que se refere à demonstração spinozista das "consequências" produzidas pelas afecções corporais, isto é, a dinâmica que estabelece a união da mente com seu corpo, tal como indicado no referido trecho da Parte II (em nosso caso, também iremos considerar as proposições 14 e 15), destacaremos, a seguir, um resumo das propriedades que este estudo considera como sendo os pontos mais importantes desse conjunto de proposições. Cabe lembrar que essa dinâmica que se estabelece a partir dos efeitos produzidos pelas afecções corporais, também é responsável pelos efeitos afetivos que surgem a partir dos encontros entre corpos, conforme iremos observar em maiores detalhes, mais adiante, no terceiro capítulo desta dissertação. Por isso, torna-se importante destacar, aqui, os seguintes aspectos das "consequências" que decorrem das afecções corporais: o corpo humano afeta e é afetado por outros corpos de diversas maneiras e a mente humana percebe tudo o que acontece no corpo (proposição 14, demonstração); a ideia do corpo que constitui o "ser formal" da mente humana não é simples, mas composta pela diversidade de ideias que envolvem a percepção da composição de todas as partes (ou indivíduos) do corpo percebido (proposição 15, demonstração); a ideia de cada maneira como o corpo é afetado deve envolver necessariamente a natureza, tanto do corpo afetado, quanto da coisa que produziu o afeto. A partir disso, conclui-se primeiro - que a mente humana "percebe a natureza de muitíssimos corpos junto com a natureza de seu corpo" (proposição 16, corolário 1) e - segundo "que as ideias que temos dos corpos externos indicam mais a constituição do nosso corpo do que a natureza dos corpos externos" (proposição 16, corolário 2); quando o corpo humano é afetado de uma maneira que envolva a natureza de

\footnotetext{
${ }^{86}$ CHAUI, M. A nervura do real II: imanência e liberdade em Espinosa, p. 170.

${ }^{87}$ Ibid.
} 
outro corpo, a mente entenderá a natureza desse corpo como existente em ato, até que seja afetado por algo que exclua a existência desse corpo e a ideia de sua presença, na mente (proposição 17). Assim, “a mente poderá contemplar, como se estivesse presente, os corpos externos pelos quais o corpo humano foi afetado uma vez, ainda que não existam nem estejam presentes” (proposição 17, corolário). Dito isso, Spinoza chama de "imagens das coisas", as afecções do corpo cujas ideias associamos ao conhecimento de outros corpos externos já existente na mente. Daí, ao afirmar que "quando a mente contempla os corpos desta maneira, diremos que ela imagina" (proposição 17, escólio); quando o corpo é afetado simultaneamente por dois ou mais corpos, quando posteriormente a mente imaginar um deles, imediatamente irá se recordar dos outros (proposição 18). Dito isso, Spinoza afirma ser claramente possível entender o que é a memória, que, segundo ele, “com efeito, não é nada outro que alguma concatenação de ideias que envolvem a natureza das coisas que estão fora do corpo humano, a qual ocorre na mente segundo a ordem e a concatenação das afecções do corpo humano" (proposição 18, escólio), que o fez concluir que "assim, cada um, a partir de um pensamento, incide em outro, conforme o costume com que cada um ordenou as imagens das coisas no corpo.” (proposição 18, escólio); “a mente humana não conhece o próprio corpo humano nem sabe que ele existe senão pelas ideias das afecções pelas quais o corpo é afetado" (proposição 19). O conhecimento do corpo depende do conhecimento de suas afecções e a mente humana só reconhece a existência de seu corpo em ato, à medida que ela produz as ideias acerca das afecções desse corpo (proposição 19, demonstração).

Certamente, ainda não temos elementos suficientes que nos permitam afirmar que o conjunto de deduções que seguem da união da mente com o corpo corresponda à totalidade da vida cognitiva, nem tampouco que se trata da formulação de uma espécie de teoria da percepção do corpo, ou algo semelhante. Até aqui, ainda que Spinoza tenha apresentado grande parte daquilo que muitos estudiosos de sua filosofia afirmam se tratar dos fundamentos de sua concepção de união da mente com o corpo, ainda estamos distantes de isso representar a totalidade da natureza dessa união. 
A pluralidade constitutiva do corpo é também constitutiva de sua ideia: o corpo é articulação interna de corpos e a mente, conexão interna de ideias, e o exercício crescente dessa pluralidade, vimos, é o critério para definir o grau de realidade ou perfeição de um corpo e de uma mente, assim como servirá, na Parte III, para determinar a diferença entre passividade e atividade, na Parte IV, a distinção entre o bom e o mau e, na Parte V, a definição da liberdade humana. ${ }^{88}$

Mesmo apresentando uma demonstração que nos permitiu conhecer, entre outras coisas, que o corpo é o objeto da ideia que constitui o ser formal da mente, que a mente percebe tudo o que acontece no corpo, e que a mente só reconhece a si mesma e a existência de seu corpo, à medida que ela produz as ideias das afecções desse corpo, ainda assim, até aqui Spinoza pouco explicou sobre como isso acontece exatamente. Isto é, ainda não sabemos como identificar essa união na realidade do modo humano de existência. Spinoza ainda não demonstrou a origem e a natureza daquilo que dará sentido ao conteúdo das ideias que produzem a dinâmica da união da mente com seu corpo, isto é, Spinoza ainda não introduziu os afetos a essa dinâmica. Contudo, ele ainda precisa completar seu percurso dedutivo sobre a natureza da mente, agora voltando-se para "a mente enquanto modo de pensamento", isto é, para a dedução dos "três gêneros do conhecimento".

\title{
3.3. \\ As ideias das afecções do corpo e a imaginação como conhecimento do primeiro gênero
}

\begin{abstract}
A mente não erra pelo fato de imaginar, mas erra somente enquanto se considera que ela carece da ideia que exclui a existência das coisas que imagina para si. ${ }^{89}$

Spinoza
\end{abstract}

Para além de ser a demonstração de um método, é preciso considerar a possibilidade de que os "três gêneros do conhecimento" deduzidos por Spinoza na segunda metade da Parte II da Ética, também se referem à continuidade da demonstração da união da mente com o corpo. Como vimos anteriormente, Chaui indica apenas as proposições de 16 a 19 como sendo a demonstração das formas e consequências da união do corpo e da mente e que, a partir disso, Spinoza "se volta para o que segue da natureza da própria mente enquanto modo

\footnotetext{
${ }^{88}$ CHAUI, M. A nervura do real II: imanência e liberdade em Espinosa, p. 170.

${ }^{89}$ SPINOZA, B. de. Ética, Parte II, Proposição XVII, Escólio, p. 169.
} 
de pensamento" $"{ }^{0}$. Ora, considerando que - conforme a proposição 15 da Parte II e sua demonstração - a ideia do corpo que constitui o "ser formal" da mente humana não é simples, mas composta pela diversidade de ideias que envolvem a percepção da composição de todas as partes (ou indivíduos) do corpo percebido, e que - conforme a proposição 19 e sua demonstração - o conhecimento do corpo depende do conhecimento de suas afecções e a mente humana só reconhece a existência de seu corpo em ato, à medida que ela produz as ideias acerca das afecções desse corpo, não estaria Spinoza, com isso, indicando que os gêneros do conhecimento, "enquanto modos de pensamento", além de envolverem a natureza da mente, não precisariam envolver também a natureza do corpo, uma vez que ele é objeto da ideia que constitui o "ser formal da mente? Além disso, se os três gêneros do conhecimento se referem às ideias que a mente concebe acerca das afecções de seu corpo existindo em ato, não estariam os gêneros do conhecimento se referindo também às formas e consequências da união da mente com o corpo, no sentido de serem a dedução dos aspectos qualitativos dessa união, ou - sendo ainda mais específico - de sua intensidade?

Os três comentadores da Parte II da Ética que foram citados no capítulo anterior, Martial Gueroult, Pierre Macherey e Marilena Chaui, são unânimes em indicar em suas obras que a "dedução da imaginação", ou do "conhecimento imaginativo", acontece no conjunto de proposições de 14 a 31 (no caso específico de Gueroult, o autor indica que essa dedução se inicia ainda no escólio da proposição 13). Porém, é preciso destacar que o debate sobre a imaginação, na obra de Spinoza, não é uma exclusividade desse conjunto de proposições da Parte II, muito pelo contrário. Em sua primeira obra, ou seja, os Princípios da filosofia cartesiana, em seu Apêndice contendo os Pensamentos metafísicos, para ser mais específico, já encontramos uma concepção inicial de imaginação. Nessa obra, Spinoza se refere à imaginação (ou ideias imaginativas) como sendo "modos de pensar" que não se referem ao "ser da ideia" ou aos "entes da razão", mas ao "ser da existência" e aos "entes fictícios":

${ }^{90}$ CHAUI, M. A nervura do real II: imanência e liberdade em Espinosa, p. 170. 
Disso claramente patenteia-se que esses modos de pensar não são ideias de coisas e de modo algum podem ser colocados entre as ideais; por isso também não tem eles nenhum ideado que exista necessariamente ou que possa existir. Porém, a causa por que esses modos de pensar são tidos como ideias de coisas é que tão imediatamente provêm e originam-se das ideias de entes reais que são facilmente confundidos com elas por aqueles que não atentam mui cuidadosamente; donde também lhes terem imposto nomes como se para significar entes que existem fora de nossa mente, e chamado tais entes, ou antes, não entes, de entes da razão. ${ }^{91}$

Posteriormente, no Tratado da emenda do intelecto, Spinoza apresenta uma concepção de imaginação que se aproxima mais do método dedutivo utilizado na Ética, contudo, ainda apresentando indícios da herança cartesiana de seus primeiros escritos.

Assim, distinguimos dessa maneira entre a ideia verdadeira e as demais percepções, e mostramos que as ideias fictícias, as falsas e as demais tem sua origem na imaginação, isto é, em algumas sensações fortuitas e (por assim dizer) soltas, que não se originam da própria potência da mente, mas de causas externas, na medida em que o corpo, seja, sonhando, seja em vigília, recebe vários movimentos. ${ }^{92}$

Por último, no apêndice da primeira parte da Ética, Spinoza já indicava que a imaginação teria grande importância para seu método do conhecimento. Antes mesmo de iniciar sua demonstração da natureza humana, na Parte II, Spinoza dedicou um longo trecho da conclusão da parte de sua obra que tem a natureza de Deus como tema, isto é, a Parte I, para antecipar alguns problemas que envolvem a imaginação. Dentre esses trechos, é importante destacar:

[...] E como esses que não entendem a natureza das coisas nada afirmam sobre elas, mas apenas as imaginam e tomam a imaginação pelo intelecto, por isso creem firmemente, ignorantes que são da natureza das coisas e da sua própria, haver ordem nas coisas. [...]

E visto que as coisas que podemos facilmente imaginar nos são mais agradáveis que as outras, por isso os homens preferem a ordem à confusão, como se a ordem fosse algo na natureza para além da relação com nossa imaginação; [...]

Em seguida, as noções restantes também nada são além de modos de imaginar, pelos quais a imaginação é afetada de diversas maneiras, e não obstante são consideradas pelos ignorantes como os principais atributos das coisas porque, como já dissemos, creem que todas as coisas são feitas em vista deles próprios e dizem que a natureza de algo é boa ou má, sã ou podre e corrompida, conforme são afetadas por ela. ${ }^{93}$

\footnotetext{
${ }^{91}$ SPINOZA, B. de. Principios da filosofia cartesiana e Pensamentos metafisicos, p. 199.

${ }^{92}$ Id., Tratado da emenda do intelecto, $\S 84$, p. 81.

${ }^{93}$ Id., Ética, Parte I, Apêndice, p. 117-119.
} 
Ainda que no caso do apêndice da primeira parte, Spinoza se refira à imaginação, especificamente, para destacar a influência negativa de sua atuação como causa da crença no finalismo de uma vontade divina que impede o conhecimento verdadeiro, e isso - naquele momento da obra - se refere ao conhecimento adequado de sua doutrina da substância única, ao mesmo tempo isso também explicita outra característica importante do conceito spinozista de imaginação, que é o fato de ela ser uma das principais causas da crença em uma natureza humana que, conforme afirma o próprio Spinoza - na abertura de seu Tratado político - "não existe em parte alguma". Essa característica específica do conceito spinozista de imaginação é particularmente importante porque os argumentos apresentados por Spinoza para justificar essa crença numa "natureza humana que não existe em parte alguma", envolve diretamente os afetos e a maneira como eles atuam na mente humana.

No entanto, voltando as atenções para a dedução dos três gêneros do conhecimento e considerando a indicação sugerida pelos comentadores, é possível afirmar que a dedução da imaginação, ou do conhecimento imaginativo, começa no mesmo trecho da obra que também marca o início da demonstração das consequências que as afecções do corpo produzem na mente, o que, aparentemente, indica se tratar de uma mesma questão. Dessa maneira, a imaginação, a princípio, seria o efeito imediato da mente que é afetada pelas ideias das afecções de seu corpo existindo em ato, o que Spinoza sugere claramente, por exemplo, na demonstração da vigésima sexta proposição.

Quando a mente humana contempla corpos externos pelas ideias das afecções de seu corpo, dizemos que então imagina; e sob nenhuma outra condição a mente pode imaginar corpos externos como existentes em ato. E por isso, enquanto a mente imagina corpos externos, não tem deles conhecimento adequado ${ }^{94}$.

É importante observar que essa demonstração explicita duas propriedades que são fundamentais para o conceito spinozista de imaginação. A primeira delas é a afirmação de que a imaginação é uma modalidade do conhecimento, ainda que, aparentemente, trate-se de um tipo de conhecimento ao qual Spinoza atribui um sentido negativo ao denominá-lo de "inadequado". A segunda propriedade afirma que a mente humana não dispõe de nenhum outro recurso

${ }^{94}$ SPINOZA, B. de. Ética, Parte II, Proposição XXVI, Demonstração, p. 181. 
para conhecer a existência do próprio corpo em ato, assim como a existência de outros corpos externos, que não seja por meio das ideias das afecções desses corpos. Portanto, a mente só conhece a existência do próprio corpo e a dos outros corpos, por meio da imaginação. Dessa maneira, diferentemente do que acontece no apêndice da primeira parte da Ética, a dedução da imaginação ou do conhecimento imaginativo, na segunda metade, da Parte II, acontece numa conjuntura mais ampla, em que a imaginação se encontra inserida no processo de união da mente com seu corpo. Não que isso signifique que a imaginação deixará de ser considerada como causa principal dos erros que impedem a mente de alcançar o conhecimento verdadeiro, pois, como afirma o próprio Spinoza na proposição 41, da Parte II - "o conhecimento de primeiro gênero [isto é, o conhecimento imaginativo] é a única causa da falsidade". Todavia, ainda que considerada como "única causa da falsidade", não se deve invalidar o conhecimento imaginativo sistematicamente, pois Spinoza ainda lhe reserva um certo sentido positivo e uma importante função em seu método dos três gêneros de conhecimento.

E aqui, para começar a indicar o que seja erro, eu gostaria que se notasse que as imaginações da mente, consideradas em si mesmas, nada contém de erro, ou seja, a mente não erra pelo fato de imaginar, mas erra somente enquanto se considera que ela carece da ideia que exclui a existência das coisas que imagina para si. Pois se a mente, quando imagina coisas não existentes como presentes a si, simultaneamente soubesse que tais coisas não existem verdadeiramente, de certo atribuiria esta potência de imaginar à virtude de sua natureza e não ao vício. ${ }^{95}$

No trecho do escólio citado acima, duas questões se destacam na explicação apresentada por Spinoza. A primeira se refere ao fato "das imaginações da mente, consideradas em si mesmas, nada conterem de erro". O que chama a atenção nessa afirmação é o fato de ela indicar que há uma existência "em si" nas coisas que são imaginadas pela mente, isto é, Spinoza reconhece a existência da imaginação como uma realidade efetiva da mente, isto é, como algo que pertence à sua natureza.

Ora, é por meio de imagens e de ideias imaginativas que estabelecemos nossa primeira experiência com as coisas e conosco mesmos. Por isso, somos levados a organizar o mundo que nos rodeia e nossa vida articulando ideias imaginativas

${ }^{95}$ SPINOZA, B. de. Ética, Parte II, Proposição XVII, Escólio, p. 169. 
que nos parecem explicar o quê, como e por que as coisas são como são e acontecem da maneira que acontecem. ${ }^{96}$

Contudo, considerando a afirmação apresentada por Spinoza - no final da demonstração da proposição 26 , da Parte II - de que "[...] enquanto a mente imagina corpos externos, não tem deles conhecimento adequado", isso significa que "a organização do mundo que nos rodeia" será marcada pela adequação entre a realidade das afecções de nosso corpo e as ideias que disso imaginamos. Por isso, o conhecimento imaginativo dos corpos externos não é uma inadequação qualquer, pois é atribuída a ele a origem de todo conhecimento "falso" que é concebido pela mente. E quanto mais as ideias inadequadas se intensificam, mais a mente irá se afastar do conhecimento verdadeiro. Um indivíduo que organiza o mundo que o rodeia a partir das ideias inadequadas das afecções de seu corpo existindo em ato, tomará o falso por verdadeiro porque o conhecimento de primeiro gênero não é um conhecimento adequado da realidade das coisas, mas apenas imaginativo, ou, como afirma Spinoza: “imagina coisas não existentes como presentes a si”.

A segunda questão que se destaca no referido trecho do escólio da proposição 26, é a indicação de que a mente erra apenas "enquanto se considera que ela carece da ideia que exclui a existência das coisas que imagina para si”. Ou seja, Spinoza indica que a causa da inadequação das ideias concebidas pela mente não se encontra propriamente nas "coisas que a mente imagina para si", mas na ausência das ideias que podem excluir a existência das coisas que são imaginadas pela mente. Por isso, Spinoza inicia o escólio afirmando "que as imaginações da mente, consideradas em si mesmas, nada contêm de erro.” Além disso, essa afirmação também sugere que a mente pode conceber ideias que são capazes de "excluir a existência das coisas que ela imagina para si, isto é, conceber as ideias que podem "excluir" os efeitos que são produzidos pelas ideias inadequadas das afecções dos corpos externos, assim como do próprio corpo. Nesse sentido, Spinoza deixa claro - na proposição 29 - que "a ideia da ideia de qualquer afecção do corpo humano não envolve o conhecimento adequado da mente humana." ${ }^{, 97}$ Isso porque, "seja qual for a ideia de qualquer

\footnotetext{
${ }^{96}$ CHAUI, M. Desejo, paixão e ação na ética de Espinosa, p. 153.

${ }^{97}$ SPINOZA, B. de. Ética, Parte II, Proposição XXIX, p. 183.
} 
afecção do corpo humano, ela envolve a natureza do corpo humano apenas enquanto este é considerado de uma certa maneira. ${ }^{" 98}$ Sendo assim, a ideia da ideia das afecções do corpo não terá como expressar adequadamente a potência de pensar da mente, isto é, sua natureza essencial. Por isso a ideia da ideia não envolve o conhecimento adequado da mente humana. Nessa circunstância,

\begin{abstract}
digo expressamente que a mente não tem de si própria, nem de seu corpo, nem dos corpos externos conhecimento adequado, mas apenas confuso e mutilado, toda vez que percebe as coisas na ordem comum da natureza, isto é, toda vez que é determinada externamente, a partir do encontro fortuito das coisas, a contemplar isso ou aquilo [...]. ${ }^{99}$
\end{abstract}

Dito isso, ao retomar a afirmação apresentada em trecho do escólio da proposição 26, de que a mente erra apenas "enquanto se considera que ela carece da ideia que exclui a existência das coisas que imagina para si”, a questão se volta, então, para a tentativa de identificar qual seria a natureza e a origem dessa ideia que Spinoza afirma poder excluir a existência das coisas que a mente imagina para si. Curiosamente, uma provável resposta para a questão encontrase na parte final do mesmo escólio que explica porque a mente não tem conhecimento adequado de si própria, nem de seu corpo, nem dos corpos externos, ou seja, o escólio da proposição 29 (cujo trecho inicial encontra-se descrito acima). Na verdade, trata-se de uma resposta que Spinoza apresenta no próprio escólio em que a questão foi colocada. Nela, Spinoza não apenas apresenta a natureza e a origem da ideia que pode "excluir a existência das coisas que imagina para si”, como também demonstra que isso é possível porque faz parte da natureza da mente e da necessidade de sua potência, poder pensar infinitas coisas em infinitos modos. Dessa maneira, se por um lado toda vez que a mente se encontrar determinada externamente a contemplar isso ou aquilo por força dos encontros fortuitos, ela não poderá ter de si mesma, nem do seu corpo, nem dos corpos externos, um conhecimento adequado, por outro lado

[...] toda vez que é determinada internamente, a partir da contemplação de muitas coisas em simultâneo, a entender as conveniências, diferenças e oposições entre elas; com efeito, toda vez que é internamente disposta desta ou daquela maneira, então contempla as coisas clara e distintamente. ${ }^{100}$

\footnotetext{
${ }^{98}$ SPINOZA, B. de. Ética, Parte II, Proposição XXVII, Demonstração, p. 181.

${ }^{99}$ Ibid., Parte II, Proposição XXIX, Escólio, p. 185.

${ }^{100}$ Ibid.
} 
Assim, Spinoza indica que as ideias adequadas, cuja potência pode excluir os efeitos provocados pelas ideias confusas e mutiladas da imaginação, se encontram na "determinação interna" que a mente possui de poder "contemplar muitas coisas em simultâneo", isto é, de poder conceber, simultaneamente, as múltiplas ideias que seguem das afecções do corpo. E essa "determinação interna", nos diz Spinoza no final do escólio, ocorre sempre quando a mente se encontra "disposta" a entender as conveniências, diferenças e oposições existentes entre elas, pois só assim, garante ele, a mente "contempla as coisas clara e distintamente." Portanto, a passagem do conhecimento imaginativo para o conhecimento racional é uma questão de determinação interna da própria mente, de sua disposição ao múltiplo simultâneo sobre as ideias que envolvem as afecções de seu corpo existindo em ato e dos corpos externos, assim como da disposição ao conhecimento pleno de sua existência, da existência de seu corpo e dos corpos externos. Somente dessa maneira, assegura Spinoza, a mente conseguirá "excluir" as ideias parciais e inadequadas que são produzidas pela mente a partir da só determinação externa das afecções de seu corpo existindo em ato. Mas, nesse caso, já não estamos mais falando da imaginação ou do conhecimento imaginativo, mas sim de uma determinação racional da mente, o que Spinoza irá abordar em seguida, quando passará a deduzir os conhecimentos de segundo e de terceiro gêneros.

\subsection{1.}

\section{A mente internamente determinada ao múltiplo e simultâneo e os conhecimentos de segundo e terceiro gêneros}

Quanto mais a Mente entende as coisas pelo segundo e pelo terceiro gêneros de conhecimento, tanto menos padece dos afetos que são maus, e menos teme a morte. ${ }^{101}$

Spinoza

Após concluir a dedução do conhecimento imaginativo, ou de primeiro gênero, a partir da proposição 32, Spinoza se volta para as etapas seguintes de sua dedução dos gêneros de conhecimentos, que são os conhecimentos de segundo e terceiro gêneros. É importante lembrar que, antes da Ética, Spinoza já havia desenvolvido um estudo sobre o método de conhecimento. Conforme ele próprio destaca - no primeiro escólio da proposição 40 - a exposição do método

${ }^{101}$ SPINOZA, B. de. Ética, Parte V, Proposição XXXVIII, p. 571. 
já havia sido apresentada anteriormente, num tratado específico que ele dedicou ao tema (referindo-se ao Tratado da emenda do intelecto) e que, portanto, não via necessidade em ser “prolixo" retomando essa questão, na Ética. Na verdade, conforme já mencionado, os gêneros de conhecimento, tal como apresentados na Parte II, referem-se ao processo dedutivo daquilo que Chaui afirma ser "[...] o que segue da natureza da própria mente enquanto modo de pensamento."

Sobre a divisão das proposições apresentadas pelos comentadores da Parte II citados por esse estudo, é possível observar que no caso de Macherey e Chaui, há um certo consenso em afirmar que a sequência de proposições de 32 a 47 se referem à dedução do "conhecimento racional" (no caso de Macherey), ou "conhecimento adequado" (no caso de Chaui). Além disso, ambos os autores indicam as proposições 48 e 49 como se referindo à dedução "do conhecimento à ação: querer e compreender" (no caso de Macherey), ou "dedução da natureza das volições (no caso de Chaui). Gueroult, por sua vez, propõe uma divisão diferente, em que apresenta a sequência de proposições de 32 a 36 como sendo a dedução da "natureza do verdadeiro e do falso", a sequência de proposições de 37 a 44 como sendo a "dedução do conhecimento de segundo gênero", outra sequência formada pelas proposições de 45 a 47 como sendo a "dedução da ciência intuitiva ou conhecimento de terceiro gênero", e, por fim, as proposições 48 e 49 como sendo a "dedução da vontade de afirmação própria da ideia".

\subsection{2.}

\section{A dedução do conhecimento de segundo gênero e as noções comuns}

Tal como indica Gueroult, em L'âme, Spinoza inicia a dedução do segundo gênero de conhecimento apresentando, inicialmente, uma distinção entre o verdadeiro e o falso.

A determinação da natureza do verdadeiro e do falso se efetua nas proposições 32 a 36 e constitui o quarto momento do Livro II. Resolvendo o problema do erro, essas proposições nos fazem passar, de fato, da esfera da imaginação àquela do entendimento, operando assim suavemente, a revolução que eleva a Alma das trevas do falso para a Luz da verdade que "manifesta a escuridão ao mesmo 
tempo que ela se manifesta”. [tradução do autor]. ${ }^{102}$

Contudo, é preciso esclarecer que esse conjunto de proposições não indica, necessariamente, que Spinoza esteja resumindo o conhecimento de segundo gênero à capacidade que a mente possui de poder distinguir entre o verdadeiro e o falso e as circunstâncias que envolvem essa determinação. Uma vez estando a mente internamente disposta ao conhecimento da realidade que envolve as ideias das afecções de seu corpo, a distinção entre o verdadeiro e o falso, como argumenta Gueroult, "nos permite passar, de fato, da esfera da imaginação àquela do entendimento". Todavia, conforme o próprio Gueroult também destaca, ainda se trata de uma primeira "etapa" do processo, "operando assim, suavemente, a revolução que eleva a alma das trevas do falso para a luz da verdade." Portanto, a passagem da imaginação ao entendimento não é um processo que ocorre de maneira imediata, mas é algo que acontece "suavemente" e envolve algumas etapas que precisam ser "experimentadas" antes que a mente consiga alcançar "a luz da verdade". E, nesse percurso de experimentações, será a disposição ao múltiplo e simultâneo que irá "conduzir" a mente na jornada de suas determinações internas pela busca do entendimento acerca das afecções de seu corpo.

Certamente, o conjunto de proposições em que Spinoza deduz a natureza do verdadeiro e do falso (proposições de 32 a 36), refere-se a duas situações diferentes. Em primeiro lugar, essa distinção estabelece o início do processo que marca a passagem da imaginação ao entendimento e, em segundo lugar, que isso é possível porque "com efeito, todas as ideias que estão em Deus convém totalmente com seus ideados." "103 Sendo assim, existe uma "correspondência" entre as ideias concebidas pela mente e o intelecto divino. Por isso, Spinoza invoca - na sequência da demonstração citada acima - primeiro, o corolário da sétima proposição, da Parte II, que esclarece: [...] O que quer que siga formalmente na natureza infinita de Deus segue objetivamente em Deus, da

\footnotetext{
102 "La détermination de la nature du vrai et du faux s'effectue dans les Propositions 32 à 36 et constitue le quatrième moment du Livre II. En résolvant le problème de l'erreur, ces Propositions nous font passer en fait de la sphère de l'imagination à celle de l'entendement, opérant ainsi sans à coup la révolution qui élève l'Ame de la nuit du faux à cette Lumière du vrai qui 'manifeste les ténèbres en même temps qu'elle se manifeste elle-même'. GUEROULT, M. Spinoza II. L'âme. (Ethique, II), p. 301.

${ }^{103}$ SPINOZA, B. de. Ética, Parte II, Proposição XXXII, Demonstração, p. 189.
} 
ideia de Deus, com a mesma ordem e a mesma conexão”. Em seguida, o sexto axioma, da Parte I, que estabelece: "a ideia verdadeira deve convir com o seu ideado." 104 Assim, Spinoza nos ensina que a passagem da imaginação ao entendimento é algo que pertence à própria natureza da mente, pois a distinção entre o verdadeiro e o falso é justificada pelo fato de que "a ideia verdadeira deve convir com o seu ideado", e essa correspondência da ideia com o ideado, por sua vez, é garantida pela natureza infinita de Deus (cujos atributos se expressam na mente) e pela "objetividade" com que a ideia segue do intelecto divino, sempre com a mesma ordem e conexão. Dito isso, Spinoza irá afirmar, na proposição 35 , que "a falsidade consiste na privação de conhecimento que as ideias inadequadas, ou seja, mutiladas e confusas, envolvem." ${ }^{105}$ Isso significa que, em relação ao conhecimento verdadeiro (portanto, não em relação às imaginações da mente), a falsidade não possui valor em si. Ela nada mais é do que uma "privação do conhecimento", cuja origem se encontra nas ideias inadequadas que a mente produz - conforme vimos, no escólio da proposição 17, da Parte II - "das coisas não existentes que a mente imagina como presentes para si”. Disso, Spinoza irá deduzir que "nada é dado de positivo nas ideias que constituem a forma da falsidade" ${ }^{, 106}$, porém - conforme antecipamos acima - em seguida Spinoza adverte que "a falsidade não pode consistir na privação absoluta (com efeito, não os corpos, mas as mentes são ditas errar e se equivocar), nem tampouco na ignorância absoluta, pois ignorar e errar são diversos." $" 107$

Após apresentar a distinção entre o verdadeiro e o falso como uma espécie de "abertura" de sua dedução do segundo gênero de conhecimento, a partir da proposição 37 - até a 40 - Spinoza se volta para as noções comuns: "Com isso, expliquei a causa das noções que são chamadas comuns e que são os fundamentos de nosso raciocínio" $" 108$, afirma Spinoza no primeiro escólio da proposição $40 .{ }^{109}$ Uma vez esclarecida essa situação, quando observamos o

\footnotetext{
${ }^{104}$ SPINOZA, B. de. Ética, Parte I, Axioma VI, p. 49.

${ }^{105}$ Ibid., Parte II, Proposição XXXV, p. 189.

${ }^{106}$ Ibid., Parte II, Proposição XXXV, Demonstração, p. 191.

107 Ibid.

${ }^{108}$ Ibid., Parte II, Proposição XL, Escólio I, p. 197.

${ }^{109}$ Conforme observado anteriormente, entre os comentadores da filosofia de Spinoza citados por esta dissertação, alguns se referem às "noções comuns" do segundo gênero como sendo a dedução do conhecimento racional, enquanto outros se referem a esse mesmo trecho como
} 
trecho da Parte II em questão (proposições de 37 a 40), de fato encontramos uma sequência dedutiva que se refere a um método de conhecimento que é estruturado a partir de noções consideradas “comuns”. É o caso, por exemplo, da proposição 38, em que Spinoza afirma que "o que é comum a todas as coisas e está igualmente na parte e no todo não pode ser concebido senão adequadamente" ${ }^{110}$. Deixando de lado a perspectiva de esse conjunto de proposições se referirem a um método do conhecimento, pois sabemos que não é isso que Spinoza está fazendo na Parte II da Ética (conforme vimos, a teoria spinozista dos gêneros de conhecimento, na verdade, se refere à dedução da "natureza da mente enquanto modo de pensamento"), ao retomar o trecho em que Spinoza deduz o conhecimento de segundo gênero e considerando, também, o fato de que essas proposições de 37 a 40 seguem o percurso iniciado anteriormente, nesse sentido podemos observar que as ideias das noções comuns não são mais aquelas ideias iniciais, que a mente produz acerca das afecções de seu corpo e dos corpos externos existindo em ato, isto é, as ideias "isoladas" pela imaginação do conhecimento de primeiro gênero, aquele que faz a mente conceber algo inexistente como presente para si. Spinoza agora nos fala da mente que "contempla muitas coisas em simultâneo", que por "entender as conveniências, diferenças e oposições", encontra-se envolvida em tudo aquilo que ela "percebe" como sendo comum às suas ideias, a si própria e ao seu corpo. "Daí segue que a mente é tanto mais apta para perceber adequadamente muitas coisas, quanto mais seu corpo tem muitas coisas em comum com outros corpos."111

Por isso Spinoza deduz o conhecimento de segundo gênero a partir das "noções comuns". Trata-se de um conhecimento cuja adequação (ou racionalidade) se intensifica à medida que a mente "percebe adequadamente as coisas", adequação essa que diz respeito às ideias que a mente produz acerca das

sendo a dedução do conhecimento adequado. De maneira geral, é possível afirmar que a dedução das "noções comuns", tal como apresentada no texto da Ética, nos permitem concluir que ambas as concepções estão corretas, evidenciando, portanto, que essa situação se trata apenas de uma diferença de terminologia, não havendo motivo para acreditar na existência de grandes divergências por parte das investigações propostas por uma ou outra concepção. Sendo assim, se referir às "noções comuns" do segundo gênero, ou como se tratando do conhecimento racional, ou como se tratando do conhecimento adequado, significa, na verdade, estar se referindo a uma mesma coisa.

${ }^{110}$ SPINOZA, B. de. Ética, Parte II, Proposição XXXVIII, p. 193.

${ }^{111}$ Ibid., Parte II, Proposição XXXIX, Corolário, p. 195-197. 
percepções do que seu corpo possui em comum com outros corpos. O conhecimento de segundo gênero se consolida na dinâmica da corporeidade de uma mente que se torna mais apta ao múltiplo e simultâneo, à medida que seu corpo se une a outros corpos e sua mente a outras mentes, que também se encontram mais aptas para conhecer as coisas adequadamente.

O que há de comum entre todos corpos e se encontra igualmente nas partes e no todo de cada corpo são relações de concordância, comunicação e constância entre seus movimentos, portanto, propriedades universais necessárias deduzidas da natureza dos corpos e que determinam as afecções corporais, cujas ideias podem ser concebidas adequadamente pela mente de cada um e de todos os seres humanos. Por isso essas ideias são denominadas por Spinoza noções comuns a todos os homens e são os fundamentos de nosso raciocínio, portanto, fundamento concreto ou real dos axiomas e postulados das ciências, das leis físicas e, como veremos na Parte IV, da sociabilidade e da vida política. ${ }^{112}$

\subsection{3.}

\section{A dedução do conhecimento de terceiro gênero e a ciência intuitiva}

No segundo escólio da proposição 40, da Parte II, Spinoza apresenta uma síntese que resume objetivamente cada um dos três gêneros de conhecimento. $\mathrm{O}$ conhecimento de primeiro gênero, ele descreve como sendo aquele que é formado "a partir de singulares, que nos são representados pelos sentidos de maneira mutilada, confusa e sem ordem para o intelecto" ${ }^{\text {"113 }}$. Além disso, também "a partir de signos, por exemplo, de que, ouvidas ou lidas certas palavras, nos recordamos das coisas e delas formamos ideias semelhantes àquelas pelas quais imaginamos as coisas." ${ }^{114}$ Dito isso, Spinoza conclui: "Chamarei daqui por diante uma e outra maneira de contemplar as coisas de conhecimento do primeiro gênero, opinião ou imaginação." ${ }^{115}$ Em seguida, Spinoza afirma: "Finalmente, porque temos noções comuns e ideias adequadas das propriedades das coisas, a isto chamarei de razão e conhecimento do segundo gênero." ${ }^{116}$ Por fim, ainda no mesmo parágrafo do escólio, Spinoza conclui que

\footnotetext{
${ }^{112}$ CHAUI, M. A nervura do real II: imanência e liberdade em Espinosa, p. 239.

${ }^{113}$ SPINOZA, B. de. Ética, Parte II, Proposição XL, Escólio II, p. 201.

${ }^{114}$ Ibid.

${ }^{115}$ Ibid.

${ }^{116}$ Ibid.
} 
além destes dois gêneros de conhecimento, é dado, tal como mostrarei na sequência, um terceiro, que chamaremos de ciência intuitiva. E este gênero de conhecimento procede da ideia adequada da essência formal de alguns atributos de Deus para o conhecimento adequado da essência das coisas. ${ }^{117}$

Sobre as sínteses apresentadas por Spinoza no segundo escólio da proposição 40, acreditamos não ser necessário acrescentar novas observações às investigações já apresentadas sobre a dedução dos conhecimentos do primeiro e do segundo gêneros, restando, apenas, seguir, "tal como mostrará Spinoza na sequência", a dedução daquilo que ele chama de "ciência intuitiva", isto é, o conhecimento de terceiro gênero.

Antes, porém, é preciso observar que na síntese apresentada pelo segundo escólio, Spinoza deixa claro - ainda que faltem as evidências - que a ciência intuitiva é um gênero de conhecimento que surge a partir das noções comuns, isto é, quando a mente - uma vez tendo concebido as ideias adequadas das propriedades das coisas (conhecimento de segundo gênero) - se volta, então, "para a ideia adequada da essência formal de alguns atributos de Deus e para o conhecimento adequado da essência das coisas." Considerando a explicação que é apresentada no escólio, aparentemente Spinoza faz da transição do segundo para o terceiro gênero, um movimento que "eleva" o conhecimento das noções comuns a uma ciência intuitiva. Essa transição, mesmo sendo algo que pertence à natureza da mente, não significa que aconteça necessariamente, toda vez que a mente "alcance" o conhecimento de segundo gênero, o que nos leva supor que nem sempre o conhecimento adequado das propriedades das coisas é uma garantia de que a mente passará automaticamente das noções comuns à ciência intuitiva, isto é, do conhecimento de segundo para o conhecimento de terceiro gênero.

Os gêneros de conhecimento, nesse sentido, se consolidam de maneira que, assim como a imaginação inicia o processo para o conhecimento das "noções comuns", este, por sua vez, possibilita o acesso ao conhecimento da "ciência intuitiva", porém, em ambos os casos, isso não é algo que acontece necessariamente, isto é, automaticamente. A passagem de um gênero do conhecimento para o outro só acontece quando surge uma causa que justifique tal modificação. Sendo assim, os três gêneros do conhecimento se consolidam

${ }^{117}$ SPINOZA, B. de. Ética, Parte II, Proposição XL, Escólio II, p. 201. 
como uma estrutura articulada capaz de demonstrar a transição da "inadequação" para a "adequação" das ideias que são concebidas pela mente. Contudo, é preciso deixar claro que o método também garante a autonomia da potência individual de cada um dos três gêneros, em que cada um deles conforme as propriedades que lhes são peculiares - é capaz de garantir, apenas por si mesmos, a consistência da ordenação e conexão entre a ideia e o ideado, independente do gênero de conhecimento em questão e independente de ser uma ideia verdadeira ou uma ideia imaginativa. Isso significa que, ao mesmo tempo em que Spinoza garante à mente um método que pode conduzi-la ao conhecimento adequado das ideias verdadeiras, ele também garante a autonomia da mente se dispor a fazer isso, somente a partir das determinações de sua própria disposição. Assim, ao recordarmos o que diz Spinoza no escólio da proposição 29: de que a mente "toda vez que é internamente disposta a contemplar muitas coisas em simultâneo, então contempla as coisas clara e distintamente" ${ }^{\not 18}$, entendemos por que as modificações do conhecimento, isto é, a passagem de um gênero do conhecimento para outro, ainda que sejam deduzidas por meio de um método, não deve ser justificado em função dele, mas tão somente em razão da disposição da própria mente, toda vez que ela desejar “contemplar muitas coisas em simultâneo".

Retomando o debate sobre a dedução do terceiro gênero, observamos que Spinoza inicia o percurso apresentando três proposições que têm por objetivo demonstrar as circunstâncias que viabilizam sua constituição. Na primeira delas, Spinoza afirma que "o conhecimento do primeiro gênero é a única causa da falsidade, o do segundo e do terceiro, por outro lado, é necessariamente verdadeiro." ${ }^{119}$ Em seguida estabelece que "o conhecimento do segundo e do terceiro gênero, e não do primeiro, nos ensina a distinguir o verdadeiro do falso." ${ }^{120}$ Por último, afirma que "quem tem uma ideia verdadeira sabe simultaneamente que tem uma ideia verdadeira e não pode duvidar da verdade certa." ${ }^{121}$ Segundo essas proposições, o surgimento do conhecimento de terceiro gênero se estabelece: em primeiro lugar porque o conhecimento de primeiro

\footnotetext{
${ }^{118}$ SPINOZA, B. de. Ética, Parte II, Proposição XXIX, Escólio, p. 183.

${ }^{119}$ Ibid., Parte II, Proposição XLI, p. 201.

${ }^{120}$ Ibid., Parte II, Proposição XLII, p. 203.

${ }^{121}$ Ibid., Parte II, Proposição XLIII, p. 203.
} 
gênero é a causa de toda falsidade (por ser inteiramente constituído por ideias inadequadas), enquanto o de segundo e de terceiro, ao contrário, são necessariamente verdadeiros (por serem inteiramente constituídos por ideias adequadas); em segundo lugar porque, uma vez que o primeiro gênero se distingue dos demais por ser inteiramente constituído de ideias inadequadas, é evidente que, uma vez privado das ideias adequadas, a partir dele não seja possível distinguir o verdadeiro do falso, enquanto que, em sentido oposto, os conhecimentos de segundo e de terceiro gêneros, por serem inteiramente formados por ideias adequadas, isto é, verdadeiras, poderão distinguir o verdadeiro do falso, pois a própria adequação de suas ideias verdadeiras permitem que ambos conheçam, tanto a causa da verdade, quanto a causa da falsidade de suas ideias, permitindo que se distinga o verdadeiro do falso.

Como vimos, nas duas primeiras proposições, Spinoza é bastante breve e pouco acrescenta ao significado descrito em seus enunciados. A proposição 43, no entanto, é acompanhada de um longo escólio em que Spinoza oferece uma explicação mais detalhada acerca dessa simultaneidade que ele afirma existir entre ter uma ideia verdadeira, saber que tem essa ideia e não duvidar da veracidade dela. Sobre essa questão, Gueroult faz uma importante observação.

\begin{abstract}
Não poderíamos concluir imediatamente que esses conhecimentos verdadeiros são, eles mesmos, o critério de sua própria verdade e, consequentemente, que qualquer um que tenha uma ideia verdadeira sabe ao mesmo tempo que ela é verdadeira e que não pode duvidar dela? Sem dúvida, mas, obtida dessa forma, essa conclusão, embora legítima, não teria nada de genética, pois ela identificaria de imediato uma ideia adequada do verdadeiro e do falso com os próprios conhecimentos adequados, sem mostrar como é possível essa identificação decorrer necessariamente de maneira determinada. Daí a obrigação de uma proposição separada: a proposição 43 e seu escólio, que, identificando a ideia adequada do verdadeiro e do falso e a ideia da ideia verdadeira, mostrará, por uma demonstração genética, que não deve nada à proposição 42 , e mostrará por que e como a ideia da ideia verdadeira é indissociável da ideia verdadeira. [tradução do autor]. ${ }^{122}$
\end{abstract}

\footnotetext{
122 "Ne pourrait-on pas en conclure immédiatement que ces connaissances vraies sont pour ellesmêmes le critère de leur propre vérité et, par conséquent, que quiconque a une idée vraie sait en même temps qu'elle est vraie et ne peut douter de sa vérité? Sans doute, mais, obtenue de la sorte, cette conclusion, quoique légitime, n'aurait de génétique, car elle identifierait d'emblée l'idée adéquate du vrai et du faux avec les connaissances adéquates elles-mêmes, sans montrer comment est possible cette identification à coup sûr nécessaire en droit. D'où l'obligation d'une Proposition séparée: la Proposition 43 et son Scolie, qui, identifiant l'idée adéquate du vrai et du faux et l'idée vraie, montrera, par un démonstration génétique qui ne doit rien à la Proposition 42, pourquoi et comment l'idée de l'idée vraie est indissociable de l'idée vraie. GUEROULT, M. Spinoza II. L'âme. (Ethique, II), p. 392-393.
} 
Portanto, a proposição 43 é apresentada como solução para uma questão de ordem "genética" sobre o estatuto de veracidade das ideias, que estaria implicado nas proposições anteriores. De fato, é preciso identificar qual critério precisa ser admitido para que uma ideia verdadeira possa, simultaneamente, ser garantia de sua própria veracidade e não deixar dúvidas sobre a verdade ao que se refere. Sobre isso, Spinoza inicialmente esclarece - na abertura da demonstração da proposição 43 - que "uma ideia verdadeira em nós é aquela que em Deus, enquanto é explicado pela natureza da mente humana, é adequada." ${ }^{123}$ Certamente, uma ideia considerada verdadeira, de início, precisará expressar, na mente humana, sua adequação em Deus. Isso significa que a adequação de uma ideia se refere a uma verdade cuja legitimidade é garantida pela correspondência com o intelecto divino, o que implica dizer que há uma relação intrínseca e uma conexão imediata entre a ideia verdadeira e o intelecto de Deus e que a adequação de uma ideia verdadeira é, antes de qualquer coisa, a expressão dessa conexão. Por isso, Spinoza invoca o corolário da décima primeira proposição, da Parte II, como uma forma de justificar essa conexão:

Daí segue que a mente humana é parte do intelecto infinito de Deus; e portanto, quando dissemos que a mente humana percebe isto ou aquilo, nada outro dizemos senão que Deus não enquanto é infinito, mas enquanto é explicado pela natureza da mente humana, ou seja, enquanto constitui a essência da mente humana, tem esta ou aquela ideia. ${ }^{124}$

Todavia, isso ainda não é suficiente para explicar qual critério precisa ser adotado para que uma ideia verdadeira possa, simultaneamente, ser garantia de sua própria veracidade e não deixar dúvidas sobre a verdade a que se refere. A conexão entre o intelecto infinito de Deus e a mente humana através da adequação da ideia verdadeira, não se dá apenas pela demonstração de que cada ideia adequada é índice de sua própria verdade, como bem destacou Gueroult. A simultaneidade de que fala Spinoza precisará envolver uma ideia de outra natureza, cuja origem encontra-se na ideia adequada que é índice de sua própria verdade. Por isso, Spinoza inicia a escólio da proposição 43, invocando o escólio da proposição 21 e justificando que ali ele já havia explicado "o que é

\footnotetext{
${ }^{123}$ SPINOZA, B. de. Ética, Parte II, Proposição XLIII, Demonstração, p. 203.

${ }^{124}$ Ibid., Parte II, Proposição XI, Corolário, p. 145-157.
} 
uma ideia da ideia". Sendo assim, surge o indício de que o critério que garante a verdade sobre a adequação das ideias do conhecimento racional de segundo e terceiro gêneros, assim como a certeza sobre as coisas que são expressas por meio das adequações dessas ideias, será uma "ideia da ideia". Nesse sentido, sobre a explicação a que Spinoza se referiu no escólio da proposição 21, cabe lembrar que:

Insisto dar-se que a ideia da mente e a própria mente seguem em Deus com a mesma necessidade da mesma potência de pensar. Pois, em verdade, a ideia da mente, isto é, a ideia da ideia, nada outro é que a forma da ideia enquanto esta é considerada como modo de pensar, sem relação com o objeto; com efeito, assim que alguém sabe algo, por isso mesmo sabe que sabe isso e, simultaneamente, sabe que sabe o que sabe, e assim ao infinito. ${ }^{125}$

Retornando ao escólio da proposição 43, observamos que a partir da noção de que toda ideia da mente "sem relação com o objeto" se trata de uma "ideia da ideia”, Spinoza primeiro se pergunta: "O que pode ser mais clara e certamente como norma da verdade do que uma ideia verdadeira?" "De fato, assim como a luz manifesta a si própria e às trevas, assim a verdade é norma de si e do falso." ${ }^{27}$ Mediante isso e conforme nos ensina Gueroult, a partir das ideias verdadeiras, serão dois os critérios (ou normas, como diz Spinoza) da verdade que irão atuar como garantias do conhecimento racional. O primeiro critério, que Gueroult chama de "primeiro grau do conhecimento adequado" (premier degré de la connaissance adéquate) ${ }^{128}$, é dado pela ideia da ideia das afecções do corpo, ou seja, as noções comuns do conhecimento do segundo gênero, que nos permitem o conhecimento adequado das propriedades das coisas que afetam nosso corpo. O segundo critério, denominado por Gueroult de "segundo grau do conhecimento adequado" (deuxième de la connaissance adéquate) ${ }^{129}$, é dado pela ideia da ideia das noções comuns, isto é, a ciência intuitiva que nos permite o "conhecimento da ideia adequada da

\footnotetext{
${ }^{125}$ SPINOZA, B. de. Ética, Parte II, Proposição XXI, Escólio, p. 175.

${ }^{126}$ Ibid., Parte II, Proposição XLIII, Escólio, p. 205.

${ }^{127}$ Ibid.

${ }^{128}$ GUEROULT, M. Spinoza II. L'âme. (Ethique, II), p. 13.

${ }^{129}$ Ibid.
} 
essência formal de alguns atributos de Deus para o conhecimento adequado da essência das coisas."

Uma vez deduzida a ideia verdadeira como norma da verdade, pois a ideia verdadeira é sempre uma ideia da ideia, isto é, uma ideia que é concebida pela mente a partir de suas próprias volições (enquanto considerada como modo de pensar), e não enquanto concebe as ideias de sua relação com os objetos (as ideias das afecções do corpo), Spinoza se volta, então, para o conhecimento que segue da ideia verdadeira, isto é, a dedução da "natureza da razão" e a potência da mente de poder conceber as ideias que envolvem a essência eterna e infinita de Deus, isto é, a ciência intuitiva do conhecimento de terceiro gênero. O primeiro movimento nesse sentido, é a dedução de que "não é da natureza da razão contemplar as coisas como contingentes, mas como necessárias." ${ }^{131} \mathrm{Na}$ demonstração que segue o enunciado acima, Spinoza afirma que "é da natureza da razão perceber as coisas como são em si, isto é, não como contingentes, mas como necessárias. ${ }^{~ 132}$ A contingência, conforme explica Spinoza no escólio que segue à demonstração, não pertence à natureza da razão, mas sim da imaginação:

\begin{abstract}
Ademais mostramos que, se o corpo humano uma vez tiver sido afetado simultaneamente por dois corpos externos, quando depois a mente imaginar um deles, de imediato se recordará também do outro, isto é, contemplará a ambos como presentes a si, a não ser que ocorram causas que excluam a existência presente deles. [...] E esta flutuação da imaginação será a mesma se for a imaginação das coisas que contemplamos da mesma maneira com relação ao tempo passado ou ao presente, e consequentemente imaginaremos como contingentes as coisas relacionadas tanto com o tempo presente quanto com o passado ou o futuro. ${ }^{133}$
\end{abstract}

A partir disso, Spinoza conclui, no segundo corolário da proposição 44, que "é da natureza da razão perceber as coisas sob algum aspecto da eternidade" $" 134$ e que "com efeito, é da natureza da razão contemplar as coisas como necessárias, e não como contingentes." ${ }^{135}$ Dessa maneira, num único movimento, Spinoza inviabilizou a contingência e a imaginação do

\footnotetext{
${ }^{130}$ SPINOZA, B. de. Ética, Parte II, Proposição XL, Escólio II, p. 201.

${ }^{131}$ Ibid., Parte II, Proposição XLIV, p. 207.

${ }^{132}$ Ibid., Parte II, Proposição XLIV, Demonstração, p. 207.

${ }^{133}$ Ibid., Parte II, Proposição XLIV, Escólio, p. 207-209.

${ }^{134}$ Ibid., Parte II, Proposição XLIV, Corolário II, p. 209.

${ }^{135}$ Ibid., Parte II, Proposição XLIV, Corolário II, Demonstração, p. 209.
} 
conhecimento racional, assim como também possibilitou o acesso ao conhecimento da essência eterna e infinita de Deus. A mente humana, como modo de pensar, poderá conhecer as coisas verdadeiramente, isto é, conforme seguem da necessidade da essência de Deus, como expressão de sua potência eterna e infinita. Por isso, Spinoza, no breve texto introdutório que abre a Parte II, se refere à mente como sendo "o que deve seguir necessariamente da essência de Deus". Ele invoca a proposição 16, da Parte $\mathrm{I}^{136}$, para justificar que “essa necessidade das coisas é a própria necessidade da eterna natureza da Deus; logo, é da natureza da razão contemplar as coisas sob este aspecto de eternidade." ${ }^{\prime 137}$ A mente, portanto, por poder expressar a necessidade que segue da essência eterna e infinita de Deus, nos permite conhecer, não apenas a natureza essencial das coisas, mas a própria natureza divina.

Uma vez que "a mente humana tem conhecimento adequado da essência eterna e infinita de Deus" ${ }^{138}$, ao deduzir isso, a partir dos gêneros do conhecimento, é possível concluir que "a mente humana tem ideias a partir das quais percebe a si, a seu corpo e aos corpos externos como existentes em ato; e, por isso, tem conhecimento adequado da essência eterna e infinita de Deus."139 Com efeito, o conhecimento adequado da natureza divina - ainda que se dê a partir da ideia verdadeira dos conhecimentos de segundo e terceiro gêneros também envolverá as ideias das afecções do corpo (conhecimento do primeiro gênero), pois, como demonstrou Spinoza, só poderá haver conhecimento adequado, à medida que a mente conhece adequadamente a si própria, o seu corpo e os corpos externos.

Daí vemos que a essência infinita de Deus e sua eternidade são conhecidas por todos. E como tudo é em Deus e é concebido por Deus, segue podermos deduzir desse conhecimento muitíssimas coisas que conhecemos adequadamente, e assim formar aquele terceiro gênero de conhecimento de que falamos no segundo escólio da proposição 40 desta parte, e de cuja excelência e utilidade nos caberá falar na quinta parte. ${ }^{140}$

\footnotetext{
136 "Da necessidade da natureza divina devem seguir infinitas coisas em infinitos modos (isto é, tudo que pode cair sob o intelecto infinito)." SPINOZA, B. de. Ética, Parte I, Proposição XVI, p. 75 .

${ }^{137}$ Ibid., Parte II, Proposição XLIV, Corolário II, Demonstração, p. 209.

${ }^{138}$ Ibid., Parte II, Proposição XLVII, p. 213.

${ }^{139}$ Ibid., Parte II, Proposição XLVII, Demonstração, p. 213.

${ }^{140}$ Ibid., Parte II, Proposição XLVII, Escólio, p. 213.
} 
Contudo, antes que isso possa indicar que a dedução dos três gêneros, por viabilizar o conhecimento adequado da essência eterna e infinita de Deus, indique que a mente possui autonomia absoluta de poder escolher livremente o que deseja ou julga ser necessário pensar, Spinoza nos lembra, na proposição 48, que "na mente não há nenhuma vontade absoluta, ou seja, livre; mas a mente é determinada a querer isso ou aquilo por uma causa, que também é determinada por outra, e esta, de novo, por outra, e assim ao infinito." ${ }^{141}$ Aqui cabe lembrar que na doutrina spinozista da substância única, "a mente é um modo de pensar certo e determinado" ${ }^{\text {142 }}$, cuja causa de sua origem é Deus e não uma substância independente que pode se determinar "a querer pensar isso ou aquilo" por meio de uma "vontade livre""143. Por isso, que

[...] não se dá na mente nenhuma faculdade absoluta de entender, desejar, amar, etc. Donde segue que estas faculdades e similares ou são inteiramente fictícias ou não são nada além de entes metafísicos, ou seja, universais que costumamos formar a partir dos particulares. ${ }^{144}$

Sendo assim, depois de afastar a imaginação e a contingência das ideias do conhecimento adequado, Spinoza agora nega a existência de uma vontade absoluta (ou livre) da mente e que essa vontade é algo que pertence à natureza da razão, isto é, pertence à natureza da mente, enquanto considerada como um modo de pensar certo e determinado. Todavia, conforme destaca Chaui em $A$ nervura do real II,

observamos que Espinosa não diz que a mente humana não é livre, pois se o dissesse não só teria destruído o escopo de sua filosofia, mas também dado razão aos que afirmaram nela ser impossível a liberdade humana. O que ele diz é que na mente humana não há uma vontade livre ou uma faculdade incondicionada de querer e não querer. ${ }^{145}$

Nesse sentido, cabe lembrar que Spinoza não se opõe à ideia cartesiana de liberdade como ausência de constrangimento externo, isto é, como ação espontânea de um agente. No entanto, ao contrário de Descartes, em que a

\footnotetext{
${ }^{141}$ SPINOZA, B. de. Ética, Parte II, Proposição XLVIII, p. 215.

142 Ibid., Parte II, Proposição XLVIII, Demonstração, p. 215.

143 "[...] cumpre aqui notar que por vontade entendo a faculdade de afirmar e negar, mas não o desejo.” Ibid., Parte II, Proposição XLVIII, Escólio, p. 215.

${ }^{144}$ Ibid.

${ }^{145}$ CHAUI, M. A nervura do real II: imanência e liberdade em Espinosa, p. 264.
} 
ausência de constrangimento externo significa considerar a liberdade como o poder absoluto de tomar decisões sem a necessidade de determinações causais, ou seja, ações cuja origem não possuem uma causa determinada, Spinoza recusa a ideia de vontade como uma faculdade absoluta de querer ou não querer e reafirma a liberdade como uma ação livre da causalidade necessária.

Não sendo a mente humana substância e sim modo determinado da substância absolutamente infinita, não pode ser causa livre de suas ações se por causa livre se entender uma faculdade absoluta de querer e não querer. Com efeito, porque somente Deus é causa absolutamente livre, pois nenhuma causa intrínseca ou extrínseca o constrange a agir, como demonstrado na proposição 17 da Parte I "Deus age somente pelas leis de sua natureza e por ninguém é coagido" conclui-se que, por existir e agir somente pela necessidade de sua natureza, apenas Ele é causa absolutamente livre, em conformidade com a definição da coisa livre. ${ }^{146}$ ["É dita livre aquela coisa que existe a partir da só necessidade de sua natureza e determina-se por si só a agir. Porém, necessária, ou antes coagida, aquela que é determinada por outro a existir e a operar de maneira certa e determinada." - Ética, Parte I, def. 7]. ${ }^{147}$

Portanto, Spinoza não atribui as ações da mente a uma faculdade absoluta da vontade considerada livre, pois essa - tal como ele afirma no apêndice da Parte I - "faz o homem ser cônscio de suas ações, mas ignorar suas causas." Para Spinoza, as ações da mente são determinações necessárias de sua própria natureza, que, à medida que conhece adequadamente as causas de suas ações, conhece a si mesmo e simultaneamente conhece a própria liberdade de poder agir intuitivamente, conforme determina a necessidade da atualização de sua potência, pois faz parte da natureza da mente ser livre à medida que ela conhece as coisas verdadeiramente (ou adequadamente), isto é, enquanto concebida como um modo de pensar que expressa a essência de Deus de maneira certa e determinada, e não enquanto uma faculdade absoluta em que seus atributos se encontram numa substância, e a natureza das causas que dão origem a tais atributos se encontram em outra.

Na última proposição da Parte II - proposição 49 - Spinoza afirma que "na mente não é dada nenhuma volição, ou seja, afirmação e negação, afora aquela envolvida pela ideia enquanto é ideia." ${ }^{148}$ Em outras palavras, Spinoza apresenta a última proposição de sua dedução da natureza da mente enquanto

${ }^{146}$ CHAUI, M. A nervura do real II: imanência e liberdade em Espinosa, p. 264.

${ }^{147}$ SPINOZA, B. de. Ética, Parte I, Definição VII, p.47.

${ }^{148}$ Ibid., Parte II, Proposição XLIX, p. 217. 
modo de pensamento, afirmando que não poderá haver qualquer afirmação ou negação da mente (quer dizer, qualquer ação da mente), que não envolva a "ideia enquanto ideia", isto é, a ideia sem relação com o objeto. É claro que Spinoza aqui se refere às afirmações e negações singulares, afinal não se trata do intelecto divino, mas dos atributos que expressam seus modos certos e determinados de pensar. Todavia é importante destacar que a dedução spinozista indica claramente que, ainda que se trate de ações singulares, cada afirmação ou negação da mente precisará envolver, tanto na ideia que afirma, quanto na ideia que nega, a ideia que exprime a natureza essencial do que está sendo afirmado ou negado pela mente. Certamente, aqui Spinoza está se referindo à ciência intuitiva do terceiro gênero de conhecimento, tal como ele demonstra no exemplo apresentado em seguida sobre um modo de pensar da mente que afirma que os três ângulos do triângulo são iguais a dois retos. "Esta afirmação envolve o conceito, ou seja, a ideia de triângulo, isto é, não pode ser concebida sem a ideia de triângulo." ${ }^{149}$ Portanto, a afirmação de que "os três ângulos de um triângulo são iguais a dois retos" não se refere a uma característica individual que explica a existência desse ou daquele triângulo em particular, mas de uma afirmação que exprime a "ideia de triângulo", isto é, a ideia que exprime a essência que define sua natureza infinita e que determina o que um triângulo é essencialmente, cuja natureza deve seguir, necessariamente, da substância eterna e infinita e seu atributo expressar, na mente humana, a ideia de triângulo com a mesma ordem e conexão de sua natureza essencial. Por isso, Spinoza invoca a segunda definição da Parte II $^{150}$ para, ao final de sua demonstração, justificar que "esta afirmação pertence à essência da ideia do triângulo e não é outro senão ela própria. E o que dissemos desta volição (visto que a tomamos ao nosso gosto) cumpre dizer também de qualquer volição, a saber, que nada é senão a ideia." 151

Toda e qualquer afirmação ou negação da mente, isto é, suas volições, nada mais são do que as ideias com que a mente afirma ou nega as coisas que

\footnotetext{
${ }^{149}$ SPINOZA, B. de. Ética, Parte II, Proposição XLIX, Demonstração, p. 217.

${ }^{150}$ Digo pertencer à essência de uma coisa aquilo que, dado, a coisa é necessariamente posta e, tirado, a coisa é necessariamente suprimida; ou aquilo sem o que a coisa não pode ser nem ser concebida e, vice-versa, que sem a coisa não pode ser nem ser concebido. Ibid., Parte II, Definição II, p. 125.

${ }^{151}$ SPINOZA, B. de, loc. cit.
} 
percebe. Daí Spinoza concluir, em seguida, que "vontade e intelecto nada são senão as próprias volições e ideias singulares. Ora, uma volição e uma ideia singular são um só e o mesmo, logo vontade e intelecto são um só e o mesmo." ${ }^{152}$ É importante lembrar que antes dessa conclusão, Spinoza já havia explicado - no escólio da proposição 48 - "que por vontade entendo a faculdade de afirmar e negar, mas não o desejo; entendo, repito [reafirma Spinoza], a faculdade pela qual a mente afirma ou nega ser verdadeiro ou falso, e não o desejo pelo qual a mente apetece ou tem aversão às coisas." ${ }^{, 153}$ A insistência de Spinoza em evidenciar que apenas a vontade é uma faculdade de afirmar e negar, desvinculando o desejo desse processo, tem sua razão de ser: trata-se da ruptura "que, desde Aristóteles, definira a virtude como o desejo determinado pela vontade guiada pela razão ao julgar quanto ao bem ou ao mal das coisas desejadas." "154 Essa "ruptura" que Spinoza imprime ao conceito de vontade ("faculdade de afirmar e negar") é algo fundamental, tanto para os três gêneros do conhecimento, quanto para a dedução da natureza humana. No sentido apresentado por Spinoza, a vontade, uma vez desvinculada do desejo, jamais se encontra ou tem sua origem fora do intelecto, muito pelo contrário. No conceito spinozista, a vontade é concebida como algo intrínseco à própria atividade de pensar, que responde pelas volições singulares das ideias que são concebidas pela mente. Na verdade, a "vontade" nada mais é do que uma ideia universal que explica o que é comum a todas as volições singulares, o que permite a mente afirmar ou negar as coisas que são percebidas por ela. Por isso, Spinoza irá rejeitar, ao longo do escólio da proposição 49, “[...] que a vontade se estenda para além das percepções, ou seja, da faculdade de conceber" ${ }^{\text {"155 }}$ e afirmar, em seguida, que

com efeito, mostramos que a vontade é um ente universal, ou seja, a ideia pela qual explicamos todas as volições singulares, isto é, o que é comum a todas elas. Assim, porque acreditam que essa ideia comum, ou seja, universal, de todas as volições é uma faculdade, não é de admirar de jeito nenhum que digam que essa faculdade se estende ao infinito, ultrapassando os limites do intelecto. ${ }^{156}$

\footnotetext{
${ }^{152}$ SPINOZA, B. de. Ética, Parte II, Proposição XLIX, Demonstração II, p. 219.

${ }^{153}$ Ibid., Parte II, Proposição XLVIII, Escólio, p. 215-217.

${ }^{154}$ CHAUI, M. A nervura do real II: imanência e liberdade em Espinosa, 2016, p. 266.

${ }^{155}$ SPINOZA, B. de, op. cit., Parte II, Proposição XLIX, Escólio, p. 223.

${ }^{156}$ Ibid., p. 225.
} 
Isso nos remete ao "segundo grau do conhecimento adequado" (deuxième de la connaissance adéquate) a que se refere Gueroult, aquele que nos permite o conhecimento adequado das essências das coisas. "A unidade ou inseparabilidade do ato de ideação e de volição (seu envolvimento recíproco) leva à conclusão necessária do que significa uma ideia envolver afirmação ou negação." 157 A mente concebe as ideias ao mesmo tempo em que as afirma ou as nega, num "envolvimento recíproco" de uma ação intuitiva da mente, o que em muito justifica o fato de Spinoza ter denominado o terceiro gênero do conhecimento de "ciência intuitiva".

\title{
3.4 .
}

\section{Escólio da proposição 49: as considerações finais da segunda parte da Ética e os ensinamentos da doutrina para uso da vida}

\begin{abstract}
Se agora parece árduo o caminho que eu mostrei conduzir a isso, contudo ele pode ser descoberto. ${ }^{158}$
\end{abstract}

Spinoza

Spinoza conclui a segunda parte da Ética apresentando - ao término da proposição 49 - um longo escólio cuja estrutura argumentativa é bastante semelhante ao modelo apresentado no apêndice da Parte I. Todavia, não iremos apresentar um exame detalhado da íntegra da conclusão apresentada por Spinoza, mas apenas destacar que o percurso do escólio que encerra a Parte II

se desdobra em cinco movimentos: no primeiro, é efetuada a refutação da concepção tradicional do erro como ato do juízo (vigente desde Platão e Aristóteles até Descartes); no segundo, Espinosa faz algumas recomendações prévias ao leitor; no terceiro, o alerta para o fato de que a doutrina exposta nas proposições 48 e 49 será alvo de objeções e estas são apresentadas; no quarto, as objeções são refutadas; e no último, são mencionadas as contribuições da doutrina para o uso da vida. ${ }^{159}$

Contudo, não podemos encerrar uma investigação sobre a natureza da mente humana e a vida cognitiva sem deixar de comentar o quinto e último movimento do escólio da proposição 49, ou seja, a contribuição que a doutrina do método spinozista oferece para o uso da vida.

${ }^{157}$ CHAUI, M. A nervura do real II: imanência e liberdade em Espinosa, p. 268.

${ }^{158}$ SPINOZA, B. de. Ética, Parte V, Proposição XLII, Escólio, p. 579.

${ }^{159}$ CHAUI, M., op. cit., p. 269. 
Vimos que a dedução da natureza da mente humana percorre toda Parte II da Ética e que a união da mente com o corpo é uma dinâmica que transita pelos três gêneros do conhecimento, sempre em meio a constantes variações entre imaginação, noções comuns e ciência intuitiva. Portanto, nada mais natural do que Spinoza concluir sua dedução da natureza da mente humana e a vida cognitiva, indicando o "quanto o conhecimento dessa doutrina contribui para o uso da vida." ${ }^{160}$ De início, é curioso notar que Spinoza se refere ao uso da doutrina, em função da vida e não em função da razão cognitiva, o que significa um claro indício de que Spinoza não separa uma coisa da outra. Ao examinar as quatro situações da vida em que Spinoza indica a utilidade de sua doutrina, observamos que se trata de fundamentos que dizem respeito a um tipo de ética prática "para o uso da vida", uma espécie de pequena ética dos costumes no interior da Ética, cujo objetivo do ensinamento é orientar as ações que são necessárias para que os homens possam, como diz Spinoza, "fazer livremente o que é melhor." 161

O primeiro ensinamento afirma que quando "agimos pelo só comando de Deus e que somos partícipes da natureza divina, e tanto mais quanto mais perfeita são as ações que efetuamos e quanto mais entendemos Deus."162 Como resultado, afirma Spinoza,

além de tornar o ânimo mais tranquilo de todas as maneiras, também nos ensina em que consiste nossa suma felicidade, ou seja, beatitude, a saber, no só conhecimento de Deus, pelo qual somos induzidos a fazer somente aquilo que o amor e a piedade aconselham. ${ }^{163}$

Portanto, o primeiro ensinamento da doutrina desloca a vida virtuosa de sua imagem de obediência ao poder supremo em função de uma recompensa, para colocá-la na perfeição das próprias ações que seguem da natureza de Deus, da qual tomamos parte à medida que agimos. Em outras palavras, a virtude é a felicidade que sentimos quando agimos pelo só “entendimento de Deus", isto é, quando agimos pelo só conhecimento da verdadeira causa das coisas.

\footnotetext{
${ }^{160}$ SPINOZA, B. de. Ética, Parte II, Proposição XLIX, Escólio, p. 227.

161 Ibid., p. 229.

162 Ibid., p. 227.

${ }^{163}$ Ibid., p. 227-229.
} 
O segundo nos "ensina como devemos proceder quanto às coisas da fortuna, ou seja, aquelas que não estão em nosso poder, isto é, quanto às coisas que não seguem de nossa natureza."164 Aqui, Spinoza indica que sua doutrina ensina como devemos agir mediante a indefinição das coisas que não estão em nosso poder, pois, independente do que pode e do que não pode estar sob nosso controle, o fato é que "todas as coisas seguem do decreto de Deus com a mesma necessidade" 165 e que, portanto, não há nada na fortuna que poderá abalar o ânimo de quem participa da natureza de Deus e age conforme as coisas que dela seguem. Nesse ensinamento, a doutrina de Spinoza é uma clara oposição à clássica concepção apresentada por Aristóteles - no Livro III de sua Ética a Nicômaco - de que "não deliberamos sobre aquilo que não temos o poder de fazer acontecer, isto é, não deliberamos sobre o necessário, o impossível e o contingente, mas somente sobre o possível"166, sobre "aquelas coisas que nos dizem respeito e dependem de nós" ${ }^{\$ 167}$. Para a doutrina spinozista de uma ética prática para uso da vida, a questão não é determinar quais as coisas que podemos e quais as que não podemos deliberar, “[...] pois, se não podemos conhecer todas em sua singularidade, podemos, entretanto, conhecer seu fundamento e princípio: a causalidade eficiente imanente da substância absolutamente infinita." ${ }^{168}$ Trata-se de uma doutrina da possibilidade de deliberar mediante qualquer coisa, independente delas nos dizerem respeito ou não, pois sobre as coisas às quais não temos qualquer poder por pertencerem à fortuna, resta a certeza de que todas elas, sem exceção, seguem da mesma necessidade da natureza de Deus, sempre com a mesma ordem e a mesma conexão, e à medida que nos tornamos - tal como indicou o primeiro ensinamento da doutrina - "partícipes da natureza divina", poderemos deliberar livremente sobre todas as coisas, pois fazer parte dessa natureza significa poder conceber a existência de tudo que segue de sua necessidade.

Tomando como base o que foi apresentado nos dois primeiros ensinamentos (ser partícipe da natureza divina; agir pelo comando de Deus; ter serenidade no ânimo para alcançar a suma felicidade; agir somente através do

\footnotetext{
${ }^{164}$ SPINOZA, B. de. Ética, Parte II, Proposição XLIX, Escólio, p. 229.

165 Ibid.

${ }^{166}$ CHAUI, M. A nervura do real II: imanência e liberdade em Espinosa, p. 278.

${ }^{167}$ ARISTÓTELES. Ética a Nicômaco, Livro III, p. 119.

${ }^{168}$ CHAUI, M., op. cit., p. 281.
} 
amor e da piedade; poder conhecer os princípios fundamentais que seguem da natureza de Deus, independente deles estarem ou não em nosso poder), é possível entender facilmente o que propõe Spinoza nos dois últimos ensinamentos de sua doutrina. Neles, Spinoza destaca a importância do uso da razão no exercício da vida prática, isto é, na dimensão propriamente ética da vida em sociedade e da atividade política. ${ }^{169}$ Nesse sentido, no terceiro ensinamento Spinoza afirma que "essa doutrina contribui para a vida social enquanto ensina a não ter por ninguém ódio, desprezo escárnio, cólera ou inveja." ${ }^{170}$ Em seguida, destaca que também "ensina cada um a contentar-se com o que tem e a auxiliar o próximo, não por misericórdia feminina, nem por parcialidade, nem por superstição, mas pela só condução da razão". ${ }^{171}$ No quarto e último ensinamento, Spinoza passa à dimensão política da utilidade de sua doutrina ao afirmar que "essa doutrina também contribui muito para a sociedade comum, enquanto ensina de que maneira devem ser governados e conduzidos os cidadãos, a saber, para que não sejam servos, mas para que façam livremente o que é melhor." Por fim, Spinoza anuncia:

E com isso concluí o que me tinha proposto a fazer neste escólio [da proposição 49] e com ele ponho fim em nossa Segunda Parte [da Ética], na qual considero ter explicado bastante, e tão claramente quanto permite a dificuldade do assunto, a natureza da Mente humana e suas propriedades, e ter trazido ensinamentos dos quais se podem concluir muitas coisas notáveis, extremamente úteis e necessárias de conhecer, como será estabelecido, em parte, pelo que virá a seguir. ${ }^{172}$

Com a conclusão da segunda parte da Ética, também chegamos ao fim da primeira parte da demonstração spinozista da natureza humana, isto é, a vida cognitiva. Conforme podemos observar, desde as primeiras proposições, a ordem com que Spinoza desenvolveu suas ideias foi fundamental para uma demonstração clara e objetiva de cada etapa do processo que marcou a passagem da natureza naturante para a natureza naturada, assim como também foi essencial para demonstrar a ordem com que podemos conhecer a origem dos

\footnotetext{
${ }^{169}$ Sobre essa questão, é preciso considerar que esses temas são apenas "introduzidos" pelos ensinamentos da doutrina, neste trecho do escólio. Eles serão, tal como esclarece o próprio Spinoza, desenvolvidos mais adiante, a partir da quarta parte da Ética: "[...] segundo o que exigem o tempo e o assunto, como mostrarei na Quarta Parte." SPINOZA, B. de. Ética, Parte II, Proposição XLIX, Escólio, p. 229.

${ }_{170}^{17 b i d .}$

${ }^{171}$ Ibid.

${ }^{172}$ Ibid.
} 
modos singulares. A minuciosa leitura da Ética com a qual investigamos o percurso dedutivo utilizado por Spinoza, de fato comprovou - conforme destaca Vidal Peña, ao relembrar Deleuze comentando Gueroult - a importância de "seguir a ordem das razões" apresentada por Spinoza em sua obra. Ao seguir a ordem demonstrativa utilizada na obra durante nossa leitura da segunda parte da Ética, mais surpreendente do que as explicações sobre os temas específicos relacionados à natureza da mente humana que acabamos de apresentar, foi descobrir que todos eles estão conectados entre si, fazendo parte de um sistema totalmente integrado, em que a própria imanência que segue da substância absolutamente infinita surge diante de nós a cada novo parágrafo da leitura, pedindo licença para expressar sua essência em tudo aquilo que pertence à natureza dos modos singulares, inclusive o modo humano. 


\section{4 \\ Origem e natureza dos afetos e a vida afetiva na Parte III da Ética}

Os filósofos concebem os afetos com que nos debatemos como vícios em que os homens incorrem por culpa própria. Por esse motivo, costumam rir-se deles, chorá-los, censurálos ou (os que querem parecer os mais santos) detestá-los. ${ }^{173}$

Spinoza

Diferentemente do que acontece na abertura da segunda parte da Ética, em que o texto introdutório é breve e apenas anuncia que passará a explicar o que deve seguir necessariamente da essência de Deus, na Parte III, Spinoza apresenta uma introdução que é bem mais extensa. Predominantemente marcada pelo tom crítico com que Spinoza avalia o tratamento que os autores anteriores a ele deram à investigação dos afetos, já em seu início, a introdução não hesita em afirmar que

quase todos que escreveram sobre os afetos e a maneira de viver dos homens parecem tratar não de coisas naturais, que seguem leis comuns da natureza, mas de coisas que estão fora da natureza. Parecem, antes, conceber o homem na natureza qual um império num império ${ }^{174}$. Pois creem que o homem mais perturba do que segue a ordem da natureza, que possui potência absoluta sobre suas ações, e que não é determinado por nenhum outro que ele próprio. Ademais, atribuem a causa da impotência e inconstância humana não à potência comum da natureza, mas a não sei que vício da natureza humana, a qual, por isso, lamentam, ridicularizam, desprezam ou, o que no mais das vezes acontece, amaldiçoam; e aquele que sabe mais arguta ou eloquentemente recriminar a impotência da mente humana é tido como Divino. ${ }^{175}$

Além disso, mais adiante, em outro trecho da introdução, Spinoza deixa de lado a generalização de suas ressalvas à tradição da filosofia moral e remete suas críticas diretamente a Descartes:

\footnotetext{
${ }^{173}$ SPINOZA, B. de. Tratado político, Capítulo I, p. 5.

${ }^{174}$ Segundo explicação apresentada por Marilena Chaui, em A nervura do real II, "Essa expressão é empregada por Spinoza numa tríplice significação: em seu sentido teológico, provém da Cabala e designa o lugar do homem antes da queda, quando Deus the teria dado o império do mundo; em seu sentido político, encontra-se nos autores que discutem a indivisibilidade da soberania (tem o imperium quem tem o poder de mando, o de fazer e promulgar as leis e usar a espada tanto para a guerra quanto para punir crimes) e por isso atacam as igrejas e as corporações como sediciosas, pois pretendem dividir a soberania, instituindo poderes rivais que a disputam; finalmente em seu sentido metafísico e moral, é empregada para indicar a soberania da vontade no domínio absoluto sobre todas as paixões e ações." CHAUI, M. A nervura do real II: imanência e liberdade em Espinosa, p. 287.

${ }^{175}$ SPINOZA, B. de. Ética, Parte III, Introdução, p. 233.
} 
É claro que sei que o celebérrimo Descartes, embora também tenha acreditado que a mente possui potência absoluta sobre suas ações, empenhou-se, porém, em explicar os afetos humanos por suas primeiras causas e, simultaneamente, em mostrar a via pela qual a mente pode ter império absoluto sobre os afetos; mas, a meu parecer, ele nada mostrou além da agudeza de seu grande engenho, como demonstrarei no devido lugar, pois agora quero retornar àqueles que preferem amaldiçoar ou ridicularizar os afetos e ações humanas em vez de entendê-los. ${ }^{176}$

Sabemos que Spinoza retoma as críticas a Descartes - de maneira ainda mais contundente e com maior riqueza de detalhes, no prefácio à quinta parte da Ética. Mesmo que, no caso da Parte V, o tema específico das críticas de Spinoza seja a teoria cartesiana de união da mente com o corpo por meio da glândula pineal: “[...] pois sustenta que a alma ou mente está unida principalmente a uma parte do cérebro, a saber, à glândula dita pineal, com cujo recurso a mente sente todos os movimentos excitados no corpo [... ${ }^{, 177}$. Tanto no caso do texto introdutório da Parte III, quanto no caso do prefácio à quinta parte, a motivação das críticas feitas a Descartes é justificada pelo mesmo motivo: a determinação de Spinoza em denunciar, em primeiro lugar, a indisposição de Descartes em romper com a tradição moralista do pensamento estoico: "Não é pequeno o apreço de Descartes por essa opinião" 178 (referindo-se à concepção estoica de que "os afetos dependem absolutamente de nossa vontade e que podemos imperar absolutamente sobre eles."179); e, em segundo lugar, a incapacidade da concepção cartesiana em garantir uma teoria seguramente científica sobre os afetos: “[...] empenhou-se, porém, em explicar as afetos humanos por suas primeiras causas e, simultaneamente, em mostrar a via pela qual a mente pode ter império absoluto sobre os afetos; mas, a meu parecer, ele nada mostrou além da agudeza de seu grande engenho," ${ }^{180}$ o que, de fato, Spinoza torna mais evidente ao apresentar argumentos ainda mais contundentes, no prefácio da Parte V:

E decerto não posso admirar-me o bastante que um filósofo, que firmemente sustentara nada deduzir senão de princípios conhecidos por si mesmos e nada afirmar senão aquilo que percebesse clara e distintamente, e que tantas vezes repreendera os Escolásticos por terem querido explicar coisas obscuras por meio

\footnotetext{
${ }^{176}$ SPINOZA, B. de. Ética, Parte III, Introdução, p. 233-235.

${ }^{177}$ Ibid., Parte V, Prefácio, p. 519.

178 Ibid.

${ }^{179}$ Ibid., Parte V, Prefácio, p. 517.

${ }^{180}$ Ibid., Parte III, Introdução, p. 235.
} 
de qualidades ocultas, adote uma hipótese mais oculta que todas as qualidades ocultas. [...]

Por fim, omito tudo o que ele assevera sobre a vontade e sua liberdade, pois mostrei sobejamente que é falso. ${ }^{181}$

Certamente que não se deve tomar as críticas feitas a Descartes nos dois diferentes momentos da Ética como algo que tem um fim em si mesmo, isto é, como uma simples denúncia da indisposição cartesiana em romper com a tradição moralista da concepção estoica das "paixões humanas", assim como da completa inviabilidade de sua "hipótese" sobre a glândula pineal ser reconhecida como uma tentativa de explicação científica das "paixões". $\mathrm{Na}$ verdade, tudo leva a crer que o principal objetivo de Spinoza, ao expor suas críticas ao tratamento dado por Descartes ao estudo das "paixões humanas", é evidenciar que na verdade será a doutrina de sua filosofia que irá fundar, tanto uma ruptura definitiva com a filosofia moral herdada da tradição estoica, quanto os fundamentos de uma teoria reconhecidamente científica para explicar os afetos. Aliás, nesse sentido, é preciso destacar que a reformulação conceitual que permitirá a Spinoza propor uma "ciência dos afetos", tem início com a mudança da própria terminologia adotada por ele em sua demonstração, em que expressões tradicionais que até então eram amplamente utilizadas para a abordagem da questão, tais como "emoção" ou "paixão", foram substituídas por "afetos".

O caráter inovador da teoria spinozista se manifesta primeiro ao nível do vocabulário, pela substituição das palavras 'emotio' ou 'passio' por 'affectus' para designar os movimentos afetivos do homem. Em Spinoza, não é mais o conceito de emoção que é central, mas o de afeto. ${ }^{182}$

A passagem de emotio e passio para affectus, não significa apenas uma mudança de ordem terminológica da expressão, mas também de uma ressignificação em seu sentido ontológico, uma vez que, após ter realizado duras críticas à tradição estoica e à ontologia cartesiana na primeira metade do texto introdutório da Parte III, Spinoza, a partir da segunda metade, enfim apresenta sua real pretensão ao propor tal mudança.

\footnotetext{
${ }^{181}$ SPINOZA, B. de. Ética, Parte V, Prefácio, p. 521-523.

182 JAQUET, C. A unidade do corpo e da mente: afetos, ações e paixões em Espinosa, p. 101.
} 
Porém, eis minha razão: nada acontece na natureza que possa ser atribuído a um vício dela; pois a natureza é sempre a mesma, e uma só e a mesma em toda parte é sua virtude e potência de agir, isto é, as leis e regras da natureza, segundo as quais todas as coisas acontecem e mudam de uma forma em outra, são em toda parte e sempre as mesmas, e portanto uma só e a mesma deve ser também a maneira de entender a natureza de qualquer coisa, a saber, por meio das leis e regras universais da natureza. ${ }^{183}$

Com efeito, assim como aconteceu nas partes precedentes da Ética, Spinoza invoca a doutrina da substância única para apresentar uma das maiores inovações conceituais de sua filosofia. Os argumentos apresentados na citação acima, tal como já demonstrados nas Partes I e II, reafirmam a universalidade daquilo que deve seguir necessariamente da essência de Deus, isto é, sua potência, como causalidade necessária de todas as operações naturais, assim como da ordem da Natureza inteira,

pois se a potência de agir ou virtude da Natureza é una e sempre a mesma $\mathrm{em}$ todas as suas partes, não pode haver partes da Natureza contrárias a ela ou independentes dela: o homem, portanto, não pode ser imperium in imperio nem seus afetos podem ser considerados vícios de sua vontade. ${ }^{184}$

Portanto, se a virtude da Natureza (ou sua potência de agir) é una e por toda parte ela é sempre a mesma, então a universalidade de sua potência fará com que também seja uma só e a mesma, a maneira de conhecer a natureza das coisas, independente quais sejam. "Em outras palavras, a natureza humana, os afetos, as paixões e ações humanas são parte da Natureza e devem ser conhecidos, entendidos e explicados pelas mesmas leis e regras (ou da mesma maneira) com que são entendidas e explicadas todas as coisas naturais."185 Nesse sentido, a filosofia de Spinoza se opõe totalmente à tradição da filosofia moral que concebe "os afetos como vícios em que os homens incorrem por culpa própria" ${ }^{186}$. Para Spinoza, os afetos

seguem da mesma necessidade e virtude da natureza que as demais coisas singulares, e admitem, portanto, causas certas pelas quais são entendidos, e

\footnotetext{
${ }^{183}$ SPINOZA, B. de. Ética, Parte III, Introdução, p. 235.

${ }^{184}$ CHAUI, M. A nervura do real II: imanência e liberdade em Espinosa, p. 293.

185 Ibid., p. 294.

${ }^{186}$ SPINOZA, B. de. Tratado político, Capítulo I, p. 5.
} 
possuem propriedades certas, tão dignas de nosso conhecimento quanto as propriedades de qualquer outra coisa cuja só contemplação nos deleita. ${ }^{187}$

Com efeito, a reformulação conceitual introduzida por Spinoza na abertura da Parte III afasta completamente o sentido moralista das justificativas passionais com que se costumava explicar a causa dos afetos até então. Como vimos, os afetos, assim como todas as outras coisas singulares, possuem causas certas pelas quais devem ser entendidos, assim como propriedades certas, dignas de serem concebidas por qualquer um.

Dessa maneira, os afetos negativamente valorados não são vícios, nem os positivamente valorados são virtudes; não são modelos universais de má ou de boa conduta: são coisas singulares, isto é, efeitos singulares necessários e eles próprios causas determinadas de efeitos determinados. ${ }^{188}$

Dessa maneira, não há razão para se atribuir a causa dos afetos a "vícios em que os homens incorrem por culpa própria”. Aliás, por serem coisas singulares como outra qualquer, cujos efeitos seguem necessariamente de causas que podemos conhecer à medida que concebemos suas propriedades, não há razão para acreditar que a causa dos afetos se encontre em outra natureza que não seja aquela que segue necessariamente da essência de Deus e que, portanto, o seu conhecimento se encontra tão somente na potência que a mente humana possui de conhecer as coisas adequadamente, isto é, verdadeiramente, e não por meio de "forças ocultas" que imaginamos pertencer a "uma natureza humana que - como afirma Spinoza na abertura de seu Tratado político - não existe em parte alguma." Por isso, Spinoza não poderia ter sido mais exato ao finalizar o texto de abertura da Parte III, afirmando categoricamente: "Tratarei, pois, da natureza e das forças dos afetos a da potência da mente sobre eles com o mesmo método com que tratei de Deus e da mente nas partes precedentes e considerarei as ações e apetites humanos como se fosse questão de linhas, planos ou corpos."

\footnotetext{
${ }^{187}$ SPINOZA, B. de. Ética, Parte III, Introdução, p. 235.

${ }^{188}$ CHAUI, M. A nervura do real II: imanência e liberdade em Espinosa, p. 294.

${ }^{189}$ SPINOZA, B. de, loc. cit.
} 
4.1.

\section{Sobre a estrutura da Parte III: uma breve descrição}

"A origem e natureza dos afetos" $" 190$ é demonstrada, na Terceira Parte da Ética, a partir de uma estrutura organizada em três definições, dois postulados e 59 proposições. Além disso, após o escólio da proposição 59, Spinoza reúne as definições de 48 afetos e, logo em seguida, conclui a Parte III apresentando uma “definição geral dos afetos". As três definições são: “causa adequada e causa inadequada" (definição 1); "ação enquanto somos causa adequada de algo que ocorre em nós e, ao contrário, padecimento enquanto em nós ocorre algo de que não somos causa senão parcial" (definição 2); “afeto" (definição 3 ) ${ }^{191}$. Mediante o caráter inovador introduzido pela definição de afeto, como se trata de algo completamente diferente em relação à tradição de sua época, é importante destacar que ao longo do processo dedutivo das proposições da Parte III, a expressão "afeto" - conforme esclarece a própria definição - mais do que uma simples troca de terminologia, significa que os afetos sempre irão se referir às “afecções do corpo pelas quais a potência de agir do próprio corpo é aumentada ou diminuída, favorecida ou coibida, e simultaneamente as ideias destas afecções".

Conceito eminentemente spinozano, os afetos são a expressão do relacionamento de cada homem com os outros e com o meio. Não estamos, repare-se, perante uma repetição do tradicional combate da razão com as paixões que arrastariam o homem para o mal. Em Spinoza, afeto é simplesmente afecção e ideia de

\footnotetext{
${ }^{190}$ Aqui, um fato chama a atenção. Observa-se que Spinoza utilizou, no título da Parte III, o mesmo recurso estilístico que foi utilizado no título da segunda parte. Nota-se, porém, que há uma inversão significativa na ordem de apresentação das expressões "natureza" e "origem", em que, enquanto na Parte II o título anuncia: "Da natureza e origem da mente", na Parte III, lemos: "Da origem e natureza dos afetos". Considerando o método da demonstração em ordem geométrica, tudo leva a crer que se trata de uma diferença na ordem de constituição de uma coisa e de outra: no caso da mente, a causa de sua natureza determina sua origem, enquanto no caso dos afetos, ao contrário, a causa de sua origem, determinará sua natureza. Contudo, é preciso esclarecer que Spinoza não apresenta qualquer explicação sobre o assunto.

191 "Denomino causa adequada aquela cujo efeito pode ser percebido clara e distintamente por ela mesma. E inadequada ou parcial chamo aquela cujo efeito não pode só por ela ser entendido" (definição 1); "Digo que agimos quando ocorre em nós ou fora de nós algo de que somos causa adequada, isto é, quando de nossa natureza segue em nós ou fora de nós algo que pode ser entendido clara e distintamente só por ela mesma. Digo, ao contrário, que padecemos quando em nós ocorre algo, ou de nossa natureza segue algo, de que não somos causa senão parcial" (definição 2); "Por afeto entendo as afecções do corpo pelas quais a potência de agir do próprio corpo é aumentada ou diminuída, favorecida ou coibida, e simultaneamente as ideias destas afecções. Assim, se podemos ser causa adequada de alguma destas afecções, então por afeto entendo ação; caso contrário, paixão" (definição 3). SPINOZA, B. de. Ética, Parte III, Definições, p. 237.
} 
afeç̧ão, choque de dois corpos em movimento de que resulta sempre uma afetividade ou grau de intensidade, seja negativa - as 'paixões tristes', como o ressentimento e a amargura, que diminuem a potência do indivíduo - seja positiva - as 'paixões alegres', como a coragem e o amor, que representam um acréscimo de potência. ${ }^{192}$

Diferentemente do que acontece nas partes precedentes da Ética, em que as propriedades universais das Partes I e II foram estabelecidas como “axiomas", na Parte III, Spinoza optou por apresentá-las como "postulados". Conforme destacado anteriormente, apenas em duas ocasiões da Ética, Spinoza denomina um conjunto de "propriedades universais" como "postulados": após as definições da Parte III e após o lema 7, da "pequena física" intercalada entre as proposições 13 e 14, da Parte II. Aparentemente, a situação se refere apenas a uma diferença de terminologia, algo que o próprio Spinoza torna evidente quando afirma, na conclusão do primeiro postulado, da Parte III: "este postulado ou axioma". Porém, independente da questão terminológica, o que importa de fato é que os dois postulados da Parte III, assim como acontece com os axiomas das outras partes da Ética, dizem respeito ao que é universal (uma propriedade universal, ou noção comum) sobre o tema a que seus enunciados se referem, que, no caso da terceira parte, ambos dizem respeito ao corpo humano ${ }^{193}$. Sendo assim, o primeiro postulado estabelece que "o corpo humano pode ser afetado de muitas maneiras pelas quais sua potência de agir é aumentada ou diminuída, e também de outras que não tornam sua potência de agir nem maior nem menor"194; e o segundo postulado, por sua vez, afirma que "o corpo humano pode padecer muitas mudanças, retendo, contudo, as impressões ou vestígios dos objetos e, consequentemente, as mesmas imagens das coisas."

Entre os estudos sobre a dedução spinozista dos afetos na terceira parte da Ética, destacamos os que foram desenvolvidos por Pierre Macherey e Marilena Chaui. Macherey, na obra Introduction à l'Ethique de Spinoza. La troisième partie: la vie affective, sugere que, ao longo das 59 proposições da Parte III, a dedução apresentada por Spinoza encontra-se tematicamente dividida em seis

\footnotetext{
192 SPINOZA, B. de. Tratado político, Capítulo I (nota do tradutor), p. 5.

${ }^{193}$ Aqui cabe observar que os dois postulados da Parte III, assim como os seis que encerram a "pequena física", na Parte II, possuem, em comum, o mesmo tema: o corpo humano.

${ }^{194}$ Id., Ética, Parte III, Postulado I, p. 237.

${ }^{195}$ Ibid., Parte III, Postulado II, p. 237.
} 
partes. ${ }^{196}$ Chaui, por sua vez, na obra $A$ nervura do real II: imanência $e$ liberdade em Espinosa, sugere que a dedução spinozista das 59 proposições, encontra-se dividida em quatro partes. ${ }^{197}$ Porém, como este estudo não tem a pretensão de investigar todos os detalhes da dedução spinozista dos afetos ao longo de suas 59 proposições, iremos apenas destacar os aspectos que podem ser considerados mais significativos para a dedução da natureza humana e a vida afetiva, que é o principal objetivo da última parte desta dissertação. Por isso, diferentemente do que foi feito nas etapas anteriores, nossa abordagem sobre a "origem e natureza dos afetos" não irá abranger todos os temas demonstrados por Spinoza.

Contudo, antes de seguir adiante, é preciso esclarecer que, apesar da grande inovação conceitual que a definição de afeto introduziu ao estudo da natureza humana, as investigações de Spinoza sobre as paixões humanas não são uma exclusividade da Ética, mas é algo que se encontra presente em sua obra desde os primeiros escritos. Chantal Jaquet, em A unidade do corpo e da mente: afetos, ações e paixões em Espinosa, chama a atenção para essa questão, ao nos lembrar que “[...] no Breve tratado, Spinoza cai em parte sob o golpe da crítica que ele desenvolverá na Parte III da Ética, porque ele visa à possibilidade de uma interação entre a alma e o corpo e de produção de efeitos de um sobre o outro (Breve tratado, Parte II, cap.19, §11-14)." ${ }^{198}$ Portanto, em relação à tradição da filosofia moral de sua época - que, como vimos, é duramente criticada por Spinoza no texto de abertura da Parte III - nem sempre o pensamento de Spinoza pode ser considerado tão inovador assim. De fato, quando observamos o referido capítulo da segunda parte do Breve tratado,

\footnotetext{
196 "Os fundamentos naturais e as formas elementares da vida afetiva (proposições de 1 a 11)" [Les fondements naturels et les formes élémentaires de vie affective (propositions 1 à 11)]; "As manifestações secundárias da afetividade e a formação da relação com o objeto (proposições de 12 a 20)" [Les manifestations secondaires de l'affectivité et la formation de la relation d'objet (propositions 12 à 20)]; "As figuras interpessoais da afetividade e o mimetismo afetivo (proposições de 21 a 34)" [Les figures interpersonnelles de l'affectivité et le mimétisme affectif (propositions 21 à 34)]; "Os conflitos afetivos (proposições de 35 a 47)" [Les conflits affectifs (propositions 35 à 47)]; "Acidentes e variações da vida afetiva (proposições de 48 a 57)" [Accidents et variations de la vie affective (propositions 48 à 57)]; "Os afetos ativos (proposições 58 e 59)" [Les affects actifs (propositions 58 et 59)]. MACHEREY, P. Introduction à l'Ethique de Spinoza: la troisième partie, la vie affective, (sumário), p. V-VII.

${ }^{197} \mathrm{Sem}$ especificar as proposições que correspondem a cada grupo, Chaui identifica os quatro temas como: "A ciência dos afetos"; "Os fundamentos da vida afetiva"; "A gênese das paixões"; "Da paixão à ação".

${ }^{198}$ JAQUET, C. A unidade do corpo e da mente: afetos, ações e paixões em Espinosa, p. 68.
} 
encontramos uma concepção de relação mente-corpo e uma teoria das paixões apresentada por Spinoza que explicita claramente as marcas da influência cartesiana de seus primeiros escritos:

Como já dissemos, a mente e o corpo podem fazer com que os espíritos que se moviam para um lado se movem agora para o outro; porém, como esses espíritos também podem ser movidos e determinados por causa do corpo, pode ocorrer amiúde que, tendo um movimento em uma direção por causa do corpo, e simultaneamente em outra por causa da mente, isso produza e cause em nós angústias como a que por vezes percebemos em nós sem que saibamos a razão disso. $^{199}$

No entanto, também é preciso considerar o fato de que o Breve tratado é um texto bem anterior à Ética (acredita-se que seja anterior até mesmo ao início de sua redação) e que, portanto, trata-se de uma das poucas obras do período em que Spinoza ainda seguia a doutrina cartesiana em seus estudos, o que, teoricamente, justifica a observação apresentada por Jaquet. Entre o Breve tratado e a Ética, nota-se que Spinoza, à medida que se afastava da doutrina cartesiana, foi "elaborando", aos poucos, sua própria teoria das paixões, até culminar em sua concepção definitiva, na terceira parte da Ética, fato, inclusive, que podemos observar quando comparamos o referido trecho do Breve tratado, com trechos de obras posteriores, tais como, por exemplo, o $\S 21$ do Tratado da emenda do intelecto:

Entretanto, concluímos a partir de outra coisa do seguinte modo: depois que claramente nós percebemos sentir tal corpo e nenhum outro, a partir disso, digo claramente concluímos que a alma está unida ao corpo, a qual união é a causa de tal sensação; mas, a partir disso absolutamente, não podemos inteligir o que seja aquela sensação e união. ${ }^{200}$

$\mathrm{Ou}$, ainda, em algumas passagens que se encontram no prefácio do Tratado teológico-político, entre as quais destacamos:

[...] que ela [a superstição] deve ser extremamente variável e inconstante, como todas as ilusões da mente e os acessos de furor; e, por último, que só a esperança,

\footnotetext{
${ }^{199}$ SPINOZA, B. de. Breve tratado de Deus, do homem e do seu bem-estar, Segunda parte, capítulo XIX, § 11, p. 131-132.

${ }^{200}$ Id., Tratado da emenda do intelecto, $\S 21$, p. 39.
} 
o ódio, a cólera e a fraude podem fazer com que subsista, pois não provém da razão, mas unicamente da paixão, e da paixão mais eficiente. ${ }^{201}$

Portanto, entre afirmar inicialmente, no Breve tratado, que "a mente e o corpo podem fazer com que os espíritos que se moviam para um lado se movem agora para o outro", para posteriormente (cerca de quinze a dezenove anos depois) deduzir, na Ética, que "nem o corpo pode determinar a mente a pensar, nem a mente pode determinar o corpo ao movimento, ao repouso ou a alguma outra coisa (se isso existe) ${ }^{, 202}$, observa-se que uma mudança expressiva teria ocorrido na concepção spinozista e que essa mudança resultou numa ruptura a tal ponto, de ele próprio se colocar na condição de poder criticar uma tradição da qual, por um determinado período, ele próprio fez parte.

\title{
4.2. \\ Para àqueles que preferem amaldiçoar ou ridicularizar os afetos e ações humanas em vez de entendê-los: Spinoza e os fundamentos da vida afetiva
}

\begin{abstract}
A bem da verdade, se não tivessem experimentado que fazemos muitas coisas das quais depois nos arrependemos, e que frequentemente, ao nos defrontarmos com afetos contrários, vemos o melhor e seguimos o pior, nada os impediria de crer que tudo fazemos livremente. ${ }^{203}$
\end{abstract}

Spinoza

Nas proposições inicias da terceira parte da Ética é o momento em que Spinoza demonstra o caráter inovador com que sua filosofia concebe os afetos e a maneira como estão diretamente relacionados à origem dos modos singulares de sua filosofia. Ao anunciar, na segunda proposição, ${ }^{204}$ que "nem o corpo pode determinar a mente a pensar, nem a mente pode determinar o corpo ao movimento, ao repouso ou a alguma outra coisa (se isso existe),205, Spinoza estabelece um princípio de "equivalência" entre as potências de determinação da mente e do corpo, para então apresentar as condições que viabilizam a relação

\footnotetext{
${ }^{201}$ SPINOZA, B. de. Tratado teológico-político, Prefácio, p. 7.

${ }^{202}$ Id., Ética, Parte III, Proposição II, p. 241.

${ }^{203}$ Ibid., Parte III, Proposição II, Escólio, p. 245.

${ }^{204}$ Sobre a primeira proposição, nos limitaremos a reproduzir apenas o que afirma Spinoza, na Demonstração: "Logo, a nossa mente, enquanto tem ideias adequadas, necessariamente age em algumas coisas, o que era o primeiro; enquanto tem ideias inadequadas, necessariamente padece algumas coisas, o que era o segundo.” Ibid., Parte III, Proposição I, Demonstração, p. 239.

${ }^{205}$ Ibid., Parte III, Proposição II, p. 245.
} 
entre interioridade e exterioridade dos modos singulares. Na obra Espinosa e o problema da expressão, Deleuze entende a referida "equivalência" entre as potências de determinação da mente e do corpo, tal como demonstrada na Ética, como se referindo a um sistema que - segundo Deleuze - além de marcar a passagem do infinito para os modos finitos, constitui uma espécie de "segunda tríade do modo finito".

Na Ética, porém, vemos que um estrito sistema de equivalências nos conduz a uma segunda tríade do modo finito: a essência como grau da potência; um certo poder de ser afetado, no qual ela se exprime; afecções que preenchem, a cada instante, esse poder.

Quais são essas equivalências? Um modo existente possui atualmente um número muito grande de partes. Ora, a natureza das partes extensivas é tal que elas 'se afetam' umas às outras ao infinito. Conclui-se daí que o modo existente é afetado de um número muito grande de maneiras. Espinosa vai das partes às suas afecções, de suas afecções às afecções do modo existente inteiro. ${ }^{206}$

Assim, Deleuze nos ensina que a equivalência entre as potências de determinação da mente e do corpo é a própria expressividade dos modos finitos, que, segundo sua teoria, na Ética são explicados, não através da concepção clássica herdada da tradição escolástica ${ }^{207}$, mas por meio de um "sistema de equivalência" entre as potências dos "modos existentes", em que eles, os próprios modos, seriam expressões imediatas dos diferentes "graus" da potência infinita, cuja essência, uma vez expressa diretamente nos modos, delega a eles, não atribuições de ordem qualitativa, mas "um certo poder de ser afetado". Sabemos que no caso da teoria deleuziana, o "estrito sistema de equivalência da segunda tríade do modo finito", não se refere necessariamente à passagem da natureza cognitiva à natureza afetiva, mas sim à passagem do infinito da substância à finitude de seus modos, o que Deleuze entende como a realidade física da "essência de modo". Portanto, para Deleuze, o "sistema de equivalência" spinozista é uma questão de ordem física que é intrínseca à natureza dos modos. De fato, se considerarmos - conforme vimos anteriormente - que a estrutura da "pequena física" (apresentada na Parte II da Ética) se refere à natureza do corpo, o que vemos agora, no "sistema de equivalência" indicado

\footnotetext{
${ }^{206}$ DELEUZE, G. Espinosa e o problema da expressão, p. 239-240.

${ }^{207}$ Segundo Deleuze, na tradição escolástica, "a tríade expressiva do modo finito se apresenta assim: a essência como grau de potência; a conexão característica na qual se exprime; as partes extensivas subsumidas sob essa conexão; e que compõe a existência do modo.” Ibid., p. 239.
} 
por Deleuze, é a consolidação de uma física dos “corpos", isto é, uma física que se estabelece a partir das afecções originadas pelo encontro entre os corpos e as ideias que a mente produz desses encontros, ou seja, os afetos.

Contudo, deixando de lado a teoria sobre a física dos modos marcar a passagem do infinito para o finito, e nos concentrando apenas na hipótese sobre o "sistema de equivalência", nesse sentido, como nos lembra Chaui, "o enunciado dessa proposição [proposição 2, da Parte III] poderia perfeitamente ser lido em chave cartesiana, não fosse a restrição posta em suas últimas palavras: 'ou a qualquer outra coisa, se outra coisa houver". ${ }^{208}$ Ao afirmar que o enunciado da segunda proposição da Parte III "poderia ser lido em chave cartesiana", Chaui está se referindo à concepção do pensamento de Descartes que explica a relação causal entre a alma e o corpo. No entanto, devido à grande complexidade que envolve a questão da causalidade na filosofia cartesiana, não iremos investigar os detalhes da afirmação de Chaui. Contudo, não podemos esquecer que a teoria cartesiana da separação substancial entre a mente e o corpo, exigiu de Descartes a demonstração de uma teoria capaz de explicar como ocorre a interação entre as duas substâncias, uma vez que ambas constituem a "natureza humana". Também sabemos que a solução encontrada por Descartes - em As paixões da alma - foi afirmar que a alma, por meio de suas volições, pode alterar os movimentos do corpo, alterando assim o que se passa nela mesma, isto é, suas paixões. Além disso, após demonstrar que o corpo não pode ser causa dos pensamentos da alma, porém precisando explicar de que maneira e em que circunstâncias pode haver, então, uma relação nãocausal entre o corpo e a alma, Descartes, mediante tal dificuldade, justifica sua teoria afirmando que o corpo pode "imprimir" suas sensações na alma, determinando, assim, suas paixões. Desse modo, a solução cartesiana foi recorrer à tradição escolástica da "primeira tríade do modo finito" de que nos fala Deleuze. Portanto, o referido trecho da segunda proposição da Parte III de que nos fala Chaui: “ou a qualquer outra coisa, se outra coisa houver", é uma resposta direcionada a essa operação da "vontade como poder da alma sobre o corpo".

${ }^{208}$ CHAUI, M. A nervura do real II: imanência e liberdade em Espinosa, p. 299. 
A segunda proposição da Ética III reafirma, portanto, que, modos de atributos realmente distintos, corpo e mente são modos realmente distintos e assim como não há relações causais entre atributos, também não há relações causais entre seus modos. A mente não move o corpo nem mesmo indiretamente, e o corpo não a determina a pensar nem mesmo indiretamente. ${ }^{209}$

Dessa maneira, mediante a impossibilidade da existência de relação causal entre a mente e o corpo, pois ambos são modos de atributos distintos, a mente não poderá mover o corpo, nem mesmo indiretamente, assim como o corpo também não poderá determinar a mente a pensar, nem mesmo indiretamente. No entanto, é importante observar que essa impossibilidade também coloca Spinoza diante do mesmo problema que foi enfrentado por Descartes. Com efeito, se a mente não pode mover o corpo e o corpo não pode determinar a mente a pensar, como explicar, então, a conexão entre os dois diferentes modos que compõem a natureza humana? Daí a importância do "sistema de equivalência" que, tal como explica Deleuze, "nos conduz a uma segunda tríade do modo finito: a essência como grau de potência; um certo poder de ser afetado, no qual ela se exprime; afecções que preenchem, a cada instante, esse poder" ${ }^{210}$. Observa-se que a segunda tríade proposta pela Ética se distancia completamente da primeira, modificando-a por completo. "A essência como grau de potência", não se exprime mais por meio de "conexões características", em que as partes extensivas resultantes das conexões compõem a existência dos modos. "Essa segunda tríade do modo finito mostra bem como é que o modo exprime a substância, participa da substância e, até mesmo, a reproduz a sua maneira."211 Na segunda tríade estabelecida pela Ética, "a essência como grau de potência", exprime a própria substância, enquanto modos com "um certo poder de ser afetado", cujas afecções, “a cada instante”, preenchem esse poder, reafirmando, assim, a própria perseverança na existência.

Em suma, uma conexão não é separável de um poder de ser afetado. Dessa maneira, Espinosa pode considerar como equivalentes duas questões fundamentais: Qual é a estrutura (fabrica) de um corpo? Que pode um corpo? A estrutura de um corpo é a composição de sua conexão. O que pode um corpo é a natureza e os limites do seu poder de ser afetado. ${ }^{212}$

\footnotetext{
${ }^{209}$ CHAUI, M. A nervura do real II: imanência e liberdade em Espinosa, p. 299.

${ }^{210}$ DELEUZE, G. Espinosa e o problema da expressão, p. 239.

${ }^{211}$ Ibid., p. 240.

${ }^{212}$ Ibid.
} 
Por isso, na demonstração que segue ao enunciado da segunda proposição da Parte III, Spinoza esclarece que "o que quer que se origine de um corpo deve originar-se de Deus enquanto considerado afetado por um modo da extensão, e não enquanto considerado afetado por um modo de pensar." ${ }^{213}$ Isto é, tudo aquilo que se refere à estrutura do corpo e as coisas que dele se originam, sempre terão como causa as afecções de outros corpos, igualmente considerados como modos da extensão de Deus, e não como modos de pensamento.

Além disso, outra questão importante que precisa ser observada na segunda proposição da Parte III, é a presença de um longo escólio no qual Spinoza dedica atenção especial à demonstração da estrutura do corpo: "Pois até aqui ninguém conheceu a estrutura do corpo tão acuradamente que pudesse explicar todas as suas funções" ${ }^{214}$, anuncia o escólio. O esforço de Spinoza encontra justificativa em sua insistência de querer afastar completamente de sua filosofia, a possibilidade de existirem relações de natureza causal entre a mente e o corpo que possam atestar a antiga crença de que a mente exerce um poder sobre as ações do corpo, assim como da crença de uma distinção entre ação e paixão, e a reversibilidade na operação dessa relação. Ao invocar o escólio da sétima proposição, da Parte II, Spinoza nos lembra que "a substância pensante e a substância extensa são uma só e a mesma substância, compreendida ora sob este, ora sob aquele atributo", 215 e que, sendo assim,

[...] mente e corpo são passivos ou ativos conjuntamente, como se depreende, aliás, da própria definição do afeto, que afirma a simultaneidade das afecções corporais e de suas ideias, e também das definições das causas adequada e inadequada, nas quais Espinosa se refere à nossa natureza e não apenas à mente (na primeira) e ao corpo (na segunda), como se esperava tradicionalmente. ${ }^{216}$

Contudo, ainda que a segunda proposição seja bastante evidente em relação à equiparação da potência e a independência dos dois modos da substância, Spinoza parece estar ciente de que isso não é suficiente para convencer os mais céticos, principalmente aqueles que aprenderam com Descartes - na Sexta Meditação - que a experiência ensina que a ideia da união

\footnotetext{
${ }^{213}$ SPINOZA, B. de. Ética, Parte III, Proposição II, Demonstração, p. 241.

${ }^{214}$ Ibid., Parte III, Proposição II, Escólio, p. 243.

${ }^{215}$ Ibid., Parte II, Proposição VII, Escólio, p. 137.

${ }^{216}$ CHAUI, M. A nervura do real II: imanência e liberdade em Espinosa, p. 302.
} 
substancial entre a alma e o corpo não é clara e distinta, mas sim algo que, para ser comprovado, precisa ser experimentado empiricamente, sob a forma de um sentimento impossível de ser negado. Por isso, no decorrer do escólio, Spinoza se faz valer da mesma estratégia utilizada por Descartes e assim reúne uma série de argumentos empíricos para demonstrar que a mente não tem qualquer poder sobre as ações do corpo. Nesse sentido, o primeiro passo foi demonstrar a independência das ações do corpo a partir dos exemplos dos animais e dos sonâmbulos:

Pois até aqui ninguém conheceu a estrutura do corpo tão acuradamente que pudesse explicar todas as suas funções, para não mencionar o fato de que nos animais são observadas muitas coisas que de longe superam a sagacidade humana, e que os sonâmbulos fazem no sono muitíssimas coisas que não ousariam na vigília; o que mostra suficientemente que o próprio corpo, só pelas leis de sua natureza, pode fazer muitas coisas que deixam sua mente admirada. ${ }^{217}$

Com base nesses argumentos, Spinoza conclui “[...] que quando os homens dizem que esta ou aquela ação se origina da mente, a qual tem império sobre o corpo, não sabem o que dizem, e nada outro fazem senão confessar, por belas palavras [numa clara referência à Sexta Meditação], que ignoram a causa daquela ação sem admirar-se disso." ${ }^{218}$ Ou seja, a experiência ensina exatamente o oposto.

Assim, se a experiência é invocada pelos que afirmam que o corpo é dirigido pela mente, então é preciso invocá-la para que ela mesma contradiga o senso comum: os animais e os sonâmbulos indicam o que realmente a experiência ensina, isto é, que os corpos realizam operações que surpreendem a própria mente. ${ }^{219}$

Após utilizar o exemplo dos animais e dos sonâmbulos para demonstrar que a mente não possui qualquer controle sobre as ações do corpo, o escólio prossegue apresentando uma série de argumentos que reforçam ainda mais a oposição que a segunda proposição, da Parte III, representa em relação à concepção do império da mente sobre o corpo: “[...] que a própria estrutura do corpo humano, de muito longe supera em artifício tudo que o que é fabricado

\footnotetext{
${ }^{217}$ SPINOZA, B. de. Ética, Parte III, Proposição II, Escólio, p. 243.

218 Ibid.

${ }^{219}$ CHAUI, M. A nervura do real II: imanência e liberdade em Espinosa, p. 304.
} 
pela arte humana. ${ }^{220}$ (uma oposição à crença de que seriam os decretos da mente os responsáveis pelas causas das coisas fabricadas pela arte humana); “[...] que a maioria creia que fazemos livremente apenas o que apetecemos de leve, já que o apetite dessas coisas pode ser facilmente diminuído pela memória de outra coisa que frequentemente recordamos." 221 Nesse trecho da argumentação, assim como já havia acontecido anteriormente, Spinoza utiliza alguns exemplos do cotidiano para ilustrar sua afirmação: "o bebê que crê apetecer livremente o leite"; "o menino irritado querer a vingança e o medroso a fuga"; "o embriagado que crer falar por livre decreto da mente aquilo que depois de sóbrio preferiria ter calado". Mediante tais exemplos, Spinoza conclui

[...] que a própria experiência, não menos claramente do que a razão, ensina que os homens creem-se livres só por causa disto: são cônscios de suas ações e ignorantes das causas pelas quais são determinados; e, além disso, ensina que os decretos da mente não são nada outro que os próprios apetites, os quais, por isso, são variáveis de acordo com a variável disposição do corpo. ${ }^{222}$

Dito isso, em seguida, Spinoza inicia a conclusão do escólio apresentando uma explicação que, além de ser essencial para a compreensão do conceito de afeto de sua filosofia, também esclarece um importante referencial teórico que Spinoza utilizará ao longo de toda a Parte III.

Pois cada um modera tudo por seu afeto, e aqueles que se defrontam com afetos contrários não sabem o que querem, ao passo que os que não lidam com nenhum são impelidos para um lado ou outro pelo menor impulso. Sem dúvida, tudo isso mostra com clareza que tanto o decreto da mente quanto o apetite e a determinação do corpo são simultâneos por natureza, ou melhor, são uma só e mesma coisa, que quando considerado sob o atributo pensamento e por ele explicado, denominamos decreto e, quando considerado sob o atributo extensão e deduzido das leis do movimento e do repouso, chamamos determinação.

Disso, portanto, conclui-se que a vida afetiva será marcada por uma simultaneidade entre os decretos da mente e as determinações do corpo e que a variação entre uma coisa e outra - como nos ensinou Deleuze - será determinada por um sistema de equivalência entre as potências dos atributos pensamento e extensão, na qual sua efetividade se encontra nos diferentes

\footnotetext{
${ }^{220}$ SPINOZA, B. de. Ética, Parte III, Proposição II, Escólio, p. 245.

${ }^{221}$ Ibid.

${ }^{222}$ Ibid.
} 
"graus" da potência infinita, cuja essência, uma vez expressa pelos dois atributos, delega a eles "um certo poder de ser afetado", e será a partir dessa variação - conforme veremos mais adiante - que Spinoza irá identificar uma constante variação da potência singular dos modos finitos.

Nesse sentido, a terceira proposição irá justamente deduzir que "as ações da mente se originam apenas das ideias adequadas; já as paixões dependem

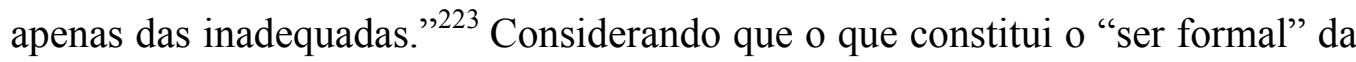
mente humana nada mais é do que a ideia de seu corpo existindo em ato, a diferença entre "ação" e "paixão", será estabelecida pela "qualidade" dessa ideia, isto é, pelo grau de realidade que a ideia da existência do corpo possui. Ora, como a segunda definição, da Parte III, não deixa dúvidas de que "agimos quando somos causa adequada", isto é, "quando segue de nós algo que pode ser entendido claramente só por ela mesma", enquanto que, ao contrário, "padecemos quando em nós acontece algo, ou de nós segue algo de que somos apenas causa parcial". Nesse sentido, toda vez em que somos causa adequada de nossas ações, a mente nunca envolverá negação e, inversamente, toda vez em que somos causa inadequada, a mente padece mediante os efeitos de paixões cujas causas ela desconhece. É importante observar que, colocando a questão nesses termos, a diferença entre ação e paixão passa a ser determinada pela clareza (ou não) da ideia com que a mente "concebe" a existência de seu próprio corpo, enquanto ele interage com outros corpos.

Uma vez esclarecido isso, é possível observar que os afetos, concebidos nessa perspectiva, tornam-se agentes responsáveis pelo desencadeamento de uma rede interativa, cujas conexões se formam a partir dos encontros entre corpos, o que exigirá de Spinoza uma demonstração das circunstâncias que envolvem tais "encontros", como é o caso, por exemplo, a questão da conservação dos corpos, que é o que veremos a seguir.

\section{3.}

\section{A mais singular expressão da potência: o conatus}

Cada coisa, o quanto está em suas forças, esforça-se para perseverar em seu ser. ${ }^{224}$

${ }^{223}$ SPINOZA, B. de. Ética, Parte III, Proposição III, p. 247.

${ }^{224}$ Ibid., Parte III, Proposição VI, p. 251. 
Sem dúvida, o conatus é um dos conceito mais importantes utilizados por Spinoza em sua ciência dos afetos. Como afirma o próprio enunciado da sétima proposição, da Parte III, “o esforço pelo qual cada coisa se esforça para perseverar em seu ser não é nada além da essência atual da própria coisa." ${ }^{225} \mathrm{O}$ conatus é a expressão da essência atual de uma coisa singular, isto é, sua potência, cujo principal objetivo é a afirmação da perseveração no próprio ser.

O conatus é a potência interna de autoperseveração na existência que toda essência singular ou todo ser singular possui porque é expressão da potência infinita da substância. Os humanos, como os demais seres singulares, são conatus, com a peculiaridade de que somente os humanos são conscientes de ser uma potência ou um esforço de perseveração na existência. O conatus, demonstra Espinosa na Parte III da Ética, é a essência atual do corpo e da mente. Mais do que isto. Sendo uma força interna para existir e conservar-se na existência, o conatus é uma força interna positiva ou afirmativa, intrinsecamente indestrutível, pois nenhum ser busca a autodestruição. O conatus possui, assim, uma duração ilimitada até que causas exteriores mais fortes e mais poderosas o destruam. Definindo corpo e mente como conatus, Espinosa os concebe essencialmente como vida, de maneira que, na definição da essência humana, não entra a morte. Esta é o que vem do exterior, jamais do interior. ${ }^{226}$

As coisas singulares, portanto, são conatus, e esta é a sua própria essência. Como se trata de expressões singulares da potência infinita da substância única, por isso trata-se da mais singular potência de afirmação da própria existência. A intensa articulação entre corpos na duração dos modos singulares, deve ser compreendida como sendo a própria variação da essência dos mesmos. O próprio esforço para perseverar na existência, isto é, o conatus, é uma condição determinante para esse fim, pois como bem demonstra a citação acima: "nenhum ser busca a autodestruição". Como um esforço que impulsiona as coisas singulares a manter-se na existência, a essência do homem, por exemplo, será regida pelos encontros de corpos com outros corpos, que igualmente esforçam-se para perseverar na existência. No entanto, é preciso destacar um importante detalhe no enunciado de Spinoza: a referida essência da coisa singular, enquanto "tende a perseverar no seu ser", é a essência atual da coisa. Ou seja, a essência de uma coisa singular não é algo fixo. Ainda que conserve sua configuração corporal, essa essência se modifica constantemente, conforme as alterações da potência de seu conatus. Na prática, isso significa que o modo

\footnotetext{
${ }^{225}$ SPINOZA, B. de. Ética, Parte III, Proposição VII, p. 251.

${ }^{226}$ CHAUI, M. Desejo, paixão e ação na ética de Espinosa, p. 84-85.
} 
humano de existência, assim como todos os outros modos singulares, se modifica o tempo todo, conforme as alterações do conatus. Portanto, nossa essência, isto é, nós mesmos, nos modificamos constantemente. E à medida que nos encontramos com os corpos de outros modos singulares, nós os afetamos e somos por eles afetados, conectados a uma rede causal marcada pela intercorporeidade. Sendo assim, como a essência singular é algo variável, a afirmação de sua existência será igualmente variável. Daí pode-se concluir que, na relação com outros corpos, nossa singularidade se modificará sempre que assim determinar nosso conatus. A nossa essência, então, será sempre produto dessa relação causal e nada poderia ser diferente, pois tudo aquilo que afirmamos através do conatus só o fazemos porque não poderia ser de outra maneira.

Mais adiante, no escólio da nona proposição, Spinoza afirma que

este esforço, quando referido à só mente, chama-se vontade; mas quando é referido simultaneamente à mente e ao corpo chama-se apetite, que portanto não é nada outro que a própria essência do homem, de cuja natureza necessariamente segue aquilo que serve à sua conservação; e por isso o homem é determinado a fazê-lo. ${ }^{227}$

Sendo assim, enquanto se refere apenas à mente, nosso esforço em perseverar na existência, isto é, nosso conatus, é a determinação de nossa "vontade" e quando se refere à mente e ao corpo, em simultâneo, torna-se nosso “apetite”. Contudo, na continuação do escólio, Spinoza irá reconhecer que entre apetite e desejo não há qualquer diferença, exceto pelo fato de que o desejo, em relação ao homem, significa ser cônscio do próprio apetite: “o desejo é o apetite quando dele se tem consciência", conclui Spinoza. Dito isso, o escólio finaliza com uma frase que expressa com exatidão a dimensão que o desejo adquire quando dele tomamos consciência: "De tudo isso, constata-se então que não nos esforçamos, queremos, apetecemos, nem desejamos nada porque o julgamos bom; ao contrário, julgamos que algo é bom porque nos esforçamos por ele, o queremos, apetecemos e desejamos. ${ }^{, 228}$ Como a mente é a ideia das afecções de seu corpo existindo em ato, à medida em que ela se torna cônscia do apetite de

\footnotetext{
${ }^{227}$ SPINOZA, B. de. Ética, Parte III, Proposição IX, Escólio, p. 255.

${ }^{228}$ Ibid.
} 
seu corpo, isso significa que irá produzir uma ideia acerca da percepção desse apetite, isto é, a mente produz uma ideia da ideia dessa percepção e, assim, a consciência do apetite do corpo torna-se desejo na mente. Por isso, Spinoza afirma que "o desejo é o apetite quando dele se tem consciência".

A simultaneidade entre as afecções do corpo e suas ideias na mente, mais uma vez é fundamental para o processo de consolidação do modo humano de existência, dessa vez para a afirmação da essência do homem. Como sabemos pela terceira definição, da Parte III - que os "afetos são as afecções do corpo pelas quais a potência de agir do próprio corpo é aumentada ou diminuída, favorecida ou coibida, assim como as ideias destas afecções”, podemos concluir, desse modo, que no encontro entre corpos, sempre que uma afecção aumentar ou diminuir, favorecer ou prejudicar a potência de um corpo, assim como de suas ideias na mente, isso significa que haverá uma diferença entre as afecções que em nada modificam o estado de conservação do corpo e da mente, e as afecções que, pelo contrário, alteram completamente a potência de ambos.

\begin{abstract}
Para evitar qualquer conclusão apressada, é preciso notar previamente que uma afecção do corpo é uma condição necessária, mas não uma condição suficiente da constituição do afeto. Espinosa restringe, com efeito, a definição do conceito de afeto apenas às 'afecções que aumentam ou diminuem, ajudam ou coíbem a potência de agir do corpo' e às 'ideias dessas afecções'. Em outras palavras, todo afeto é uma afecção, mas nem toda afecção é um afeto. ${ }^{229}$
\end{abstract}

Conforme destaca Jaquet na citação acima, é importante estar atento ao detalhe de que a definição spinozista de afeto não deixa dúvidas de que afetos são apenas as afecções do corpo que, em conjunto com as ideias na mente, modificam a potência de agir, tanto do corpo (sua determinação ao movimento ou ao repouso, em resposta às afecções sentidas), quanto da mente (sua determinação em afirmar ou negar as ideias das afecções sentidas pelo corpo).

Além da definição estabelecer a essência do afeto como uma espécie de "consciência" da variação de potência singular do corpo e da mente, não devemos esquecer que Spinoza reafirma essa variação também como uma propriedade que os afetos imprimem ao corpo. Ao anunciar - no primeiro postulado da Parte III - que "o corpo humano pode ser afetado de muitas

${ }^{229}$ JAQUET, C. A unidade do corpo e da mente: afetos, ações e paixões em Espinosa, p. 125. 
maneiras pelas quais sua potência de agir é aumentada ou diminuída, e também de outras que não tornam sua potência de agir nem maior nem menor, ${ }^{\text {,230, }}$ Spinoza não está mais se referindo aos efeitos que os afetos produzem na variação da potência do conatus de uma coisa singular, mas afirmando que essa variação só acontece por causa de certas propriedades que são intrínsecas ao corpo humano. Que propriedades seriam? Spinoza responde invocando o postulado 1 e os lemas 5 e 7, da "pequena física", que, conforme vimos no capítulo anterior, se referem à dedução das propriedades do corpo humano. E quais seriam essas propriedades? "O corpo humano ser composto de muitíssimos indivíduos (de natureza diversa), cada um dos quais sendo bastante composto" (postulado 1); "as partes componentes de um indivíduo sofrerem modificações de tamanho, mas em tal medida que todas conservam a mesma proporção de movimento e de repouso, de forma um indivíduo conseguir manter sua natureza sem nenhuma mudança de forma" (lema 5); "além disso, o indivíduo composto, quer se mova por inteiro, quer esteja em repouso, quer se mova para um lado ou para outro, desde que cada parte mantenha o seu movimento e que comunique esse movimento às outras partes, nessa medida o indivíduo composto manterá sua natureza" (lema 7). Portanto, ainda que os afetos se refiram às afecções do corpo que produzem modificações na potência de uma coisa singular, Spinoza nos lembra que o corpo humano é composto de "muitíssimos indivíduos", cada um composto de muitas partes.

O envio ao postulado 1 [da "pequena física"] permite compreender que essa aptidão do corpo a ser afetado, tanto de maneiras que aumentam ou diminuem sua potência de agir quanto de maneiras que nem a aumentam nem a diminuem, é ligado ao fato de que ele 'é composto de um grande número de indivíduos (de natureza diversa), cada um dos quais é assaz composto'. Logo, sua enorme complexidade explica que o corpo humano esteja disposto a uma multiplicidade indefinida de estados, do mais desfavorável ao mais favorável à sua potência de agir, passando pelos neutros e mais indiferentes. Os dois lemas, 5 e 7, corroboram essa análise, mostrando os limites dessa aptidão a ser afetado e definindo a extensão de seu domínio. ${ }^{231}$

Sendo assim, isso nos permite concluir que a dinâmica afetiva que envolve o corpo e a mente também envolve outros indivíduos e, tal como vimos na

\footnotetext{
${ }^{230}$ SPINOZA, B. de. Ética, Parte III, Postulado I, p. 237.

${ }^{231}$ JAQUET, C. A unidade do corpo e da mente: afetos, ações e paixões em Espinosa, p. 127.
} 
citação acima, isso é intrínseco ao envolvimento de numerosos indivíduos, de natureza diversa, formando "uma enorme complexidade que explica porque o corpo humano esteja disposto a uma multiplicidade indefinida de estados". Nesse sentido, mediante a "multiplicidade indefinida de estados", o conatus atua de maneira decisiva enquanto potência de autopreservação e afirmação da própria essência de uma coisa singular. O conatus é uma potência interna de autoafirmação e de causalidade eficiente, que produz efeitos necessários, tanto interna quanto externamente.

Isso significa, antes de qualquer coisa, que nosso conatus opera passivamente quando somos causas eficientes parciais dos efeitos que se produzem em nós e fora de nós porque a outra parte da causalidade é realizada por forças externas a nós. Em contrapartida, somos ativos ou agimos quando somos causas eficientes totais dos efeitos que se produzem em nós e fora de nós. Somos passivos quando somos causas inadequadas, somos ativos quando somos causas eficientes totais dos afetos ou, na linguagem de Espinosa, quando somos causas adequadas. ${ }^{232}$

No que diz respeito à natureza humana e a vida afetiva, o conatus não afirma apenas a perseverança na existência, mas também é responsável pela perseverança no próprio "ser", enquanto expressão da potência do próprio conatus. A potência de nosso corpo, assim como de nossa mente, será, portanto, estabelecida pela variação do grau de intensidade de nosso esforço para perseverar na existência: no caso do corpo, isso significa se determinar ao movimento ou ao repouso, mediante suas afecções; no caso da mente, isso significa afirmar ou negar as ideais das afecções de seu corpo. Sendo assim, nosso esforço para perseverar na existência, isto é, nosso conatus, irá depender da maneira como nos relacionamos com as forças que são externas ao nosso esforço, de como nosso conatus "reage" à potência das forças que lhe são contrárias: ou se firmando como causa adequada, ou, ao contrário, sendo causa inadequada. Entre uma coisa e outra, encontra-se a determinação do conatus em alcançar o apetite do corpo do qual a mente tornou-se cônscia, isto é, encontrase o desejo. Com efeito, será a intensidade de nossos desejos que irão determinar a variação da potência vital do corpo e da mente, mas, nesse caso, a intensidade de nossos desejos - que respondem pela atualização de nossa essência - não atua sozinha nessa dinâmica. Juntamente com o desejo, Spinoza

${ }^{232}$ CHAUI, M. Desejo, paixão e ação na ética de Espinosa, p. 86. 
introduz mais dois afetos que irão fazer parte dessa dinâmica e estabelecer a variação na intensidade da potência de nosso esforço para perseverar na existência. Mas, nesse caso, já não estamos falando apenas do conatus, mas também da tríade spinozista dos afetos primários e sua ciência dos afetos, que são os próximos temas de nossa investigação sobre os fundamentos da vida afetiva.

\section{4. Desejo, alegria e tristeza: a tríade spinozista dos afetos primários}

Dão-se tantas espécies de alegria, tristeza e desejo e, consequentemente, de cada afeto que se compõe deles, como a flutuação do ânimo, ou que deles se deriva, como o amor, o ódio, a esperança o medo, etc., quantas são as espécies de objetos pelos quais somos afetados. $^{233}$

Spinoza

A tríade spinozista dos afetos primários é formada pelos afetos de desejo, alegria e tristeza. O próprio Spinoza esclarece - no escólio da décima primeira proposição, da Parte III - que “[...] por alegria entenderei na sequência a paixão pela qual a mente passa a uma maior perfeição. Por tristeza, a paixão pela qual ela passa a uma menor perfeição." ${ }^{234}$ Sobre o desejo, Spinoza destaca que já havia explicado anteriormente - no escólio da nona proposição, também da Parte III - que se trata do "apetite quando dele se tem consciência." Uma vez esclarecido o significado de cada um dos afetos da tríade primária, na continuação do escólio, Spinoza apresenta uma conclusão que é decisiva para os fundamentos de sua ciência dos afetos. Nela, Spinoza é categórico ao afirmar que "não reconheço nenhum outro afeto primário além desses três, pois mostrarei na sequência que os restantes se originam deles."235

Sem dúvida, essa é uma afirmação que causa grande impacto, principalmente no que se refere à parte final da explicação, em que Spinoza garante que todos os outros afetos terão como origem, um dos três afetos primários. Mesmo aqueles afetos cuja origem não é causada diretamente por um dos três, como é o caso da devoção, por exemplo, que Spinoza define como

\footnotetext{
${ }^{233}$ SPINOZA, B. de. Ética, Parte III, Proposição LVI, p. 327.

${ }^{234}$ Ibid., Parte III, Proposição XI, Escólio, p. 257.

235 Ibid.
} 
sendo "o amor àquele que admiramos"236, ainda assim o afeto secundário que dá origem ao afeto em questão - no caso de nosso exemplo, esse afeto secundário é o "amor" - ele terá em sua origem, um dos três afetos primários. No caso do amor, o afeto primário que é causa de sua origem, é a alegria. ${ }^{237}$ Portanto, ainda que alguns afetos não tenham sua origem determinada diretamente por um dos três afetos primários, certamente terão indiretamente, por meio de afetos que podem ser considerados secundários ou até mesmo terciários. Por isso, quando observarmos as definições dos 48 afetos apresentada no final da Parte III, com exceção da "admiração" e do "desprezo", em que ambos apresentam a "imaginação" como causa, os demais têm origem num dos três afetos primários ou num afeto secundário originado por um deles.

Desse modo, se a distinção entre afecção e afeto se configura como uma das regras básicas da ciência dos afetos de Spinoza (lembrando que por meio dessa regra aprendemos que nem toda afecção é um afeto), vemos agora a tríade dos afetos primários (enquanto causa da origem dos outros afetos), se tornar outra dessas regras. Além disso, também é importante destacar que nas "definições dos afetos" apresentada no final da Parte III, Spinoza reformula as definições dos três afetos primários, dessa vez com características mais apropriadas às exigências conceituais de uma definição: “O desejo é a própria essência do homem enquanto é concebida determinada a fazer [agir] algo por uma dada afecção sua qualquer; A alegria é a passagem do homem de uma perfeição menor a uma maior; A tristeza é a passagem do homem de uma perfeição maior a uma menor" ${ }^{\text {238 }}$. Com relação aos afetos de alegria e tristeza, notamos que não há diferença significativa entre como eles são apresentados no escólio da proposição 11, e como são estabelecidos nas "definições dos afetos". Contudo, o mesmo não pode ser dito em relação ao desejo. Nesse caso, há uma diferença significativa entre ambas as definições.

$\mathrm{Na}$ verdade, a definição inicial - apresentada no escólio da proposição 9 é reafirmada na primeira metade da segunda, pois afirmar que o desejo é o apetite do qual se toma consciência e depois afirmar que o desejo é a própria

\footnotetext{
${ }^{236}$ SPINOZA, B. de. Ética, Parte III, Definições dos afetos, Definição X, p. 345.

237 "O amor é a alegria conjuntamente à ideia de causa externa". Ibid., Parte III, Definições dos afetos, Definição VI, p. 343.

${ }^{238}$ Ibid., Parte III, Definições dos afetos, Definições I, II e III, p. 339-341.
} 
essência do homem, significa afirmar que o desejo é ambas as coisas. A diferença, portanto, encontra-se na segunda metade do enunciado da segunda definição, isto é, no trecho acrescentado posteriormente: “enquanto é concebida determinada a fazer [agir] algo por uma dada afecção sua qualquer". O próprio Spinoza oferece uma explicação - após o enunciado da segunda definição - que esclarece a questão de maneira satisfatória. Depois de destacar que já havia definido o desejo como apetite quando dele se tem consciência, ele justifica que "não quis explicar o desejo pelo apetite, mas tentei defini-lo de tal maneira que compreendesse de uma só vez todos os esforços da natureza humana que designamos pelos nomes de apetite, vontade, desejo ou ímpeto." ${ }^{239}$ Dessa maneira, Spinoza potencializa o desejo de modo a flexibilizá-lo ao máximo enquanto determinação do ímpeto humano, não se restringindo apenas ao apetite da vontade.

Portanto [conclui Spinoza ao fim da explicação], entendo aqui pelo nome desejo qualquer esforço, ímpeto, apetites e volições de um homem que, segundo a variável constituição do mesmo homem, são variáveis e não raro tão opostos uns aos outros que ele é arrastado de diversas maneiras e não sabe para onde voltar-$\mathrm{se}^{240}$

Sendo assim, entre os três afetos primários, o desejo, por se tratar da própria essência do homem, enquanto determinação à ação em razão de uma afecção qualquer, possuirá uma função especial. Isso porque, enquanto os afetos de alegria e de tristeza expressam as "modificações" do ânimo, isto é, a "passagem do homem de uma perfeição menor a uma maior" (no caso da alegria) e a "passagem do homem de uma perfeição maior a uma menor" (no caso da tristeza), o desejo, por sua vez, será o afeto que, mediante os efeitos provocados por uma afecção qualquer que aumenta ou diminui a potência do corpo e da mente, terá como função ser o "agente" da ação que responderá a tais efeitos. Ou seja, diferentemente da alegria e da tristeza, o desejo não se refere a uma "modificação", mas à determinação da "ação" que responde diretamente aos efeitos produzidos por uma afecção em que a própria potência do corpo e da mente é diretamente afetada.

${ }^{239}$ SPINOZA, B. de. Ética, Parte III, Definições dos afetos, Definição I, Explicação, p. 339.
${ }^{240}$ Ibid. 
Contudo, antes de concluirmos essa breve investigação sobre a tríade spinozista dos afetos primários, é importante destacar que essa propriedade do desejo não o torna um afeto mais importante do que os demais. Como vimos, a alegria e a tristeza são diretamente responsáveis pelas modificações do estado de perfeição do homem. Considerando que Spinoza - conforme vimos na sexta definição, da Parte II - afirma que "por realidade e perfeição entende o mesmo", ao definir a alegria como a "passagem do homem de uma perfeição menor a uma maior", isso significa que o homem se alegra à medida que ele passa de um menor para um maior conhecimento acerca da realidade em que se encontra envolvida a potência de seu corpo e a potência de sua mente, assim como, em sentido contrário, ao definir a tristeza como a "passagem do homem de uma perfeição maior a uma menor", isso significa que o homem se entristece à medida que ele passa de um maior para um menor conhecimento acerca da realidade em que se encontra envolvida a potência atual de seu corpo e de sua mente. Desse modo, mediante as afecções que alteram a potência de agir do corpo e da mente, se o desejo é o afeto responsável pela afirmação de nossa potência atual de existir, os afetos de alegria e de tristeza, são responsáveis pelo conhecimento que temos acerca da atualidade de nossa realidade. Na tríade spinozista dos afetos primários, não temos como controlar se esse ou aquele afeto nos é mais ou menos favorável. Mediante as circunstâncias que envolvem os encontros entre os corpos que afetam nossa potência de ser e agir, a dinâmica afetiva que irá nos envolver terá sempre como horizonte a afirmação de nosso esforço de perseverar na existência. Portanto, será a determinação de nosso conatus que irá estabelecer a natureza de como seremos afetados pela potência das coisas que são externas à nossa potência de existir. Por tudo isso, tal como já havia feito nas partes precedentes da Ética, Spinoza irá demonstrar a natureza afetiva do homem através de uma ciência que seguirá leis certas e determinadas, possíveis de serem entendidas clara e distintamente.

\section{5.}

\section{A ciência dos afetos}

Tratarei, pois, da natureza e das forças dos afetos e da potência da mente sobre eles com o mesmo método com que tratei de Deus e da mente nas partes precedentes e 
considerarei as ações e apetites humanos como se fosse questão de linhas, planos ou corpos. ${ }^{241}$

Spinoza

Para concluir nossa investigação sobre os fundamentos da vida afetiva, é importante destacar alguns aspectos da chamada ciência dos afetos da Ética. Conforme afirmamos anteriormente, a ciência spinozista dos afetos surge a partir de duas regras básicas. A primeira regra, como vimos, é estabelecida pela própria definição de afeto, em que Spinoza deixa claro que afeto são "as afecções do corpo pelas quais a potência de agir do próprio corpo é aumentada ou diminuída, favorecida ou coibida, assim como as ideias dessas afecções." Nessa perspectiva, a definição estabelece uma distinção entre afecção e afeto, no sentido de que, apesar de todo afeto ser necessariamente originado por uma afecção, nem toda afecção torna-se um afeto que modifica a potência de agir do corpo e da mente. A segunda regra é estabelecida pela afirmação - no escólio da proposição 11 - de que os "afetos primários", isto é, desejo, alegria e tristeza, são responsáveis pela origem de todos os outros afetos. Uma vez que os afetos estão intrinsecamente associados às afecções do corpo, cabe lembrar que Spinoza estabelece - na décima terceira proposição, da Parte II - que "o objeto da ideia que constitui a mente humana é o corpo, ou seja, um modo certo da extensão, existente em ato, e nada outro.” Portanto, se os afetos são afecções do corpo que produzem modificações em sua potência de agir, isso significa que também irão envolver modificações das ideias na mente do corpo afetado, isto é, os afetos são afecções que produzem modificações conjuntamente no corpo e na mente: no corpo, enquanto ação de alternância entre movimento ou repouso; na mente como volições que afirmam ou negam as ideias que a mente imagina para si do corpo afetado.

Num primeiro momento, essa constatação não parece fazer tanta diferença para uma abordagem dinâmica dos afetos, mas quando voltamos nossas atenções para o texto da Parte III, observamos que a partir da décima segunda proposição, Spinoza inicia uma longa sequência - até a proposição 55 - em que grande parte das proposições irá se referir a uma relação direta entre a dedução dos afetos e as operações da imaginação. De fato, se lembrarmos que, entre

${ }^{241}$ SPINOZA, B. de. Ética, Parte III, Introdução, p. 235. 
outras coisas, Spinoza explica, na Parte II, que a imaginação são ideias parciais e inadequadas que a mente produz pela só determinação externa das afecções de seu corpo existindo em ato, é natural que a associação imediata entre as afecções do corpo e as imaginações da mente também ocorram naturalmente. Além disso, também não podemos deixar de observar que, dada a natureza de contrariedade atribuída às definições dos afetos de alegria e tristeza (ambos pertencentes à tríade dos afetos primários), "isso esclarece por que, via de regra, os afetos são apresentados como pares de opostos, conforme derivem da alegria ou da tristeza - amor e ódio, esperança e medo, soberba e abjeção, e assim por diante." 242 No caso do terceiro afeto da tríade, isto é, o desejo, como se trata de uma determinação a uma ação em resposta às afecções que envolvem as modificações da potência do corpo e da mente, os afetos que a partir dele se originam não irão envolver contrariedade, mas ações que irão expressar as variações entre movimento e repouso. Portanto, não há contrariedade no desejo, há apenas ações que irão afirmar ou negar a demanda imposta pelo apetite do corpo e da mente ao qual o desejo se refere.

Sendo assim, é possível concluir que no encontro entre corpos, a relação entre a potência de agir de um corpo e a potência dos demais, irá surgir uma dinâmica afetiva cuja origem estará num dos três afetos primários. Quando esse afeto for de alegria ou de tristeza, isso significa que esse corpo foi afetado por uma paixão de sua mente: uma paixão alegre (no caso do afeto de alegria) ou uma paixão triste (no caso do afeto de tristeza). Por isso, no escólio da décima primeira proposição, da Parte III, Spinoza se refere à alegria como "a paixão pela qual a mente passa a uma maior perfeição", enquanto à tristeza, ele se refere como sendo "a paixão pela qual a mente passa a uma menor perfeição". Desse modo, os afetos de alegria e de tristeza se referem às "paixões da mente", isto é, às ideias que a mente imagina para si acerca das afecções de seu corpo existindo em ato, enquanto o desejo se refere - segundo o escólio da nona proposição - ao "apetite quando dele se tem consciência", se refere, portanto, a uma "ação do corpo" quando se tem consciência de seu desejo. Certamente que essa consciência do próprio desejo também envolve a mente, mas, nesse caso, não se trata de uma "paixão", mas de uma "determinação" da mente que afirma

${ }^{242}$ CHAUI, M. A nervura do real II: imanência e liberdade em Espinosa, p. 326. 
ou nega a ideia do desejo de seu corpo. Por fim, a hipótese que esta dissertação insiste em defender aqui é a de que, mais importante do que uma investigação sobre o restante da dedução spinozista sobre a origem e natureza dos afetos, é tentar evidenciar ao máximo que a dinâmica afetiva da teoria dos afetos primários encontra-se nos fundamentos da vida afetiva, estabelecendo seus princípios básicos e proporcionando uma estrutura cujo principal objetivo é explicar os afetos enquanto causa eficiente das determinações da potência singular do modo humano de existência.

As definições dos três afetos primários - desejo, alegria e tristeza - indicam que a gênese das paixões decorre do cruzamento de duas causalidades eficientes - a causalidade interna do conatus e a causalidade externa ou operação das coisas externas - e dos entrecruzamentos dos três afetos primários, de maneira que a definição de cada paixão deverá explicitar em que condições e como se dão aquele cruzamento causal e esse entrecruzamento afetivo, demonstrando para isso [tal como já destacamos anteriormente] as operações imaginativas realizadas pela mente. ${ }^{243}$

Uma vez esclarecida a importância que os três afetos primários representam para a natureza do homem e sua potência de agir, Spinoza inicia, então - a partir da décima segunda proposição - a dedução dos afetos a partir das operações imaginativas que, de maneira geral, possui a seguinte ordem demonstrativa:

começará com a demonstração da relação com as coisas externas [proposição 12]; em seguida, introduzirá o tempo, fazendo intervir a memória e os processos cognitivos de associação de ideias ou imagens [proposição 13]; prosseguirá com a dedução das paixões conforme as diferentes maneiras como se dão os encontros fortuitos do corpo e da mente com as coisas externas, fazendo aparecer a complexidade crescente da vida passional [proposições de 14 a 18]; o crescimento dessa complexidade colocará em cena as diferentes maneiras como acontece a relação com a alteridade, o outro podendo ser uma coisa ou um ser humano, relação inicialmente dual e, posteriormente, triádica [proposições de 19 a 34]; finalmente, introduzirá relações entre as próprias paixões, que se alteram reciprocamente, reforçando-se mutuamente ou contrariando-se [proposições de 35 a 59$].{ }^{244}$

Ainda que, ao longo do percurso dedutivo que demonstra a atuação da imaginação, Spinoza apresente uma série de operações afetivas que são

\footnotetext{
${ }^{243}$ CHAUI, M. A nervura do real II: imanência e liberdade em Espinosa, p. 330.

${ }^{244}$ Ibid.
} 
fundamentais para explicar a natureza humana, como no caso, por exemplo, da afirmação - na demonstração da proposição 18 - de que "enquanto o homem for afetado pela imagem de alguma coisa, contemplará a coisa como presente, ainda que não exista."245; ou ainda quando afirma - na proposição 28 - que nós “esforçamo-nos para fazer que aconteça tudo o que imaginamos conduzir à alegria; ao passo que nos esforçamos para afastar ou destruir o que imaginamos opor-se a isso, ou seja, conduzir à tristeza" ${ }^{246}$, no que diz respeito aos interesses de nossa investigação, apesar da grande importância que o tema representa para o estudo dos afetos, não iremos apresentar aqui os detalhes dessa demonstração, bastando, em nosso caso, mencionar apenas os temas tidos como mais gerais, algo que acabamos de destacar na citação acima.

Após o percurso dedutivo da estrutura dos afetos por meio das operações da imaginação, Spinoza inicia uma sequência em que apresenta as definições de 59 afetos, para, enfim, encerrar a Parte III da Ética, apresentando uma “definição geral dos afetos". Sobre as 59 definições, observa-se que se trata de enunciados em que, como era de se esperar, os afetos são definidos a partir de suas essências, isto é, aquilo que estabelece a natureza essencial de cada afeto definido, independente de suas origens. Muitas dessas definições são acompanhadas de explicações. São dispositivos que funcionam como uma espécie de complemento ao enunciado, oferecendo informações adicionais que ajudam a evidenciar certas propriedades que pertencem à natureza do afeto que foi definido. Além disso, conforme já havíamos antecipado, as definições também evidenciam o que Spinoza já havia anunciado - no escólio da décima primeira proposição, da Parte III - isto é, que todos os 59 afetos possuem origem num dos três afetos primários e "surgem" a partir, ou de uma alegria, ou de uma tristeza ou de um desejo, seja de maneira direta, quando o afeto é um efeito imediato de um dos três, como no caso da "esperança", por exemplo, que é definido por Spinoza como sendo "a alegria inconstante originada da ideia de uma coisa futura ou passada de cuja ocorrência até certo ponto duvidamos" ${ }^{, 247}$, ou de maneira indireta, quando o afeto é um efeito secundário, ou até mesmo terciário, de um dos três afetos primários, como no caso, por exemplo, da

\footnotetext{
${ }^{245}$ SPINOZA, B. de. Ética, Parte III, Proposição XVIII, Demonstração, p. 267.

${ }^{246}$ Ibid., Parte III, Proposição XXVIII, p. 281

${ }^{247}$ Ibid., Parte III, Definições dos afetos, Definição XII, p. 347.
} 
"devoção", que é definida por Spinoza como sendo "o amor àquele que admiramos" 248 .

Sobre a "definição geral dos afetos" e sua explicação - que marcam o encerramento da terceira parte, da Ética - Spinoza utiliza a expressão pathema para estabelecer que o afeto, concebido como paixão do ânimo, “é uma ideia confusa pela qual a mente afirma de seu corpo ou de uma de suas partes uma força de existir maior ou menor do que antes e, "dada [essa ideia]", a mente é determinada a pensar uma coisa de preferência a outra." ${ }^{249}$ A seguir, na explicação da "definição geral", Spinoza invoca a terceira proposição, da Parte III, para nos lembrar que "as paixões dependem apenas das ideias inadequadas." 250 Por isso, a explicação afirma, de imediato, "que o afeto ou paixão do ânimo é uma ideia confusa." ${ }^{251}$ Em função disso, logo em seguida Spinoza reafirma a segunda metade da definição e enfatiza que essa "ideia confusa" é responsável pela mente afirmar de seu corpo ou de uma de suas partes, uma potência de agir maior ou menor do que existia anteriormente, pois - ainda segundo a explicação apresentada por Spinoza - "com efeito, todas as ideias que temos dos corpos indicam mais a constituição atual de nosso corpo do que a natureza do corpo externo., 252

Portanto, os afetos cuja origem se encontram nas afecções dos encontros fortuitos de nosso corpo com os corpos externos, indicam mais como percebemos a constituição e a potência de nosso próprio corpo, do que a natureza dos corpos externos que nos afetam. Ou seja, os afetos possuem causalidade externa, mas produzem efeitos internos, enquanto modificações da natureza do corpo afetado e também da natureza da mente de quem esse corpo é ideia. Por isso, Spinoza - na continuação da explicação - destaca que quando se refere a uma força de existir maior ou menor do que antes, não está querendo dizer que "a mente compara a constituição presente do corpo com a passada, mas que a ideia que constitui a forma do afeto afirma algo sobre o corpo que na verdade envolve mais ou menos realidade do que antes. ${ }^{, 253}$ Além disso, Spinoza

\footnotetext{
${ }^{248}$ SPINOZA, B. de. Ética, Parte III, Definições dos afetos, Definição X, p. 345.

${ }^{249}$ Ibid., Parte III, Definição geral dos afetos, p. 365.

${ }^{250}$ Ibid., Parte III, Proposição III, p. 247.

${ }^{251}$ Ibid., Parte III, Definição geral dos afetos, Explicação, p. 367.

${ }^{252}$ Ibid.

${ }^{253}$ Ibid.
} 
invoca as proposições 11 e 13, da Parte II (no primeiro caso para nos lembrar que a essência da mente consiste em afirmar a existência atual de seu corpo e, no segundo caso, que ele entende por perfeição a própria essência da coisa), para garantir - conforme destacamos anteriormente - que "a mente passa a uma maior ou menor perfeição quando the acontece afirmar de seu corpo ou de uma parte sua algo que envolve mais ou menos realidade do que antes. ${ }^{, 254}$ Por fim, Spinoza encerra a Parte III afirmando, em primeiro lugar, que a qualidade das ideias, isto é, "sua excelência", e a potência atual de pensar da mente, irá depender da qualidade (ou "excelência") dos objetos que são causa dessas ideias; em segundo lugar, que, mediante uma ideia qualquer, "a mente é determinada a pensar uma coisa de preferência a outra”, por que, uma vez tendo explicado - na primeira parte da definição - a natureza da alegria e da tristeza, seria necessário explicar, também, a natureza do desejo. Com essa explicação sobre a natureza do desejo, Spinoza enfim conclui sua demonstração da origem e natureza dos afetos. Diferentemente do que acontece nas partes precedentes, em que um apêndice é apresentado na conclusão da Parte I e um longo escólio, explicando a utilidade do método, finaliza a Parte II, aqui se observa um final sem uma conclusão efetiva, como se a discussão sobre o tema ainda não tivesse se esgotado.

Contudo, antes de encerrar nossa investigação sobre a vida afetiva, esta dissertação considera importante chamar atenção para a contribuição que a Parte III da Ética representa para o estudo das paixões humanas. São muitos os momentos de destaque, a começar - conforme vimos no início deste capítulo pela inovadora substituição do conceito de "paixão" pelo de "afeto". Além disso, tivemos a sutil, porém importante, distinção entre afecção e afeto. Entre os vários momentos em que a dedução spinozista associa diretamente os afetos à própria natureza humana, destacamos "o sistema de equivalência" entre as potências da mente e do corpo; a doutrina que estabelece o conatus como essência atual dos modos singulares (fazendo disso a mais singular expressão da potência divina); a dinâmica da tríade dos afetos primários (alegria, tristeza e desejo) como causalidade necessária das modificações da potência de agir do corpo e da mente, assim como causa da origem de todos os outros afetos.

${ }^{254}$ SPINOZA, B. de. Ética, Parte III, Definição geral dos afetos, Explicação, p. 367. 
Por fim, ressaltamos a importância da demonstração spinozista que, ao longo de várias proposições, destacou como os afetos exercem uma influência determinante nas ideias que a mente imagina para si acerca das afecções de seu corpo existindo em ato, levando Spinoza a concluir - na explicação da definição geral dos afetos - que as ideias que a mente concebe acerca das afecções de seu corpo, referem-se mais à natureza do próprio corpo e sua potência de agir, do que à natureza do corpo externo. Portanto, nada mais significativo do que chegar ao fim de uma investigação sobre a vida afetiva, concluindo que à medida que nos relacionamos com outros corpos, conhecemos mais a natureza do nosso próprio corpo e de nossa própria mente, do que a natureza dos corpos externos que nos afetam. 


\section{5 \\ Conclusão}

O que se diz de cada cousa em particular, diz-se do conjunto de todas as cousas. Assim, se cada cousa particular é uma manifestação particular de Deus, o conjunto de todas as cousas é a manifestação total de Deus. Ora, o conjunto de todas as cousas é a natureza ou o mundo. Portanto, a natureza ou o mundo é Deus mesmo, manifestado, é Deus mesmo tornando-se visível. ${ }^{255}$

Farias Brito

O trecho da obra de Farias Brito destacado acima é uma publicação do final do século XIX e está entre as primeiras em língua portuguesa que comentam a filosofia de Spinoza. A importância de seu pioneirismo para a difusão do pensamento de Spinoza no Brasil é inegável. No entanto, independente de seu grande valor histórico, em nosso caso, esse trecho nos é particularmente interessante por outro motivo. Trata-se de um bom exemplo para destacar uma espécie de "regra básica" que todo leitor mais atento da obra de Spinoza percebe de imediato: ao se ler a Ética, se em algum momento da obra "perde-se Deus de vista", isso significa que a leitura não está seguindo a ordem da demonstração spinozista. Fato inegável, uma vez que fica evidente, já nas primeiras proposições, da primeira parte da obra, que nada irá escapar conforme destacou Farias Brito em seu comentário - à causalidade absoluta que o Deus sive natura de Spinoza impõe a tudo aquilo que é demonstrado nas proposições da Ética.

Contudo, Merleau-Ponty - na obra Signos - ao se referir a Descartes, nos ensina algo importante que também pode ser válido para Spinoza. No capítulo $\mathrm{V}$ de sua obra, Merleau-Ponty afirma que

A razão de Descartes estar presente [na atualidade] é que, rodeado de circunstâncias hoje abolidas, obcecado por preocupações e por algumas ilusões de seu tempo, ele [Descartes] respondeu a tais acasos de maneira que nos ensina a responder os nossos, embora estes sejam diferentes e diferente também a nossa resposta. ${ }^{256}$

Certamente Spinoza acreditava na potência absoluta de seu Deus sive nature; mais que isso, ele acreditava que seu sistema filosófico - demonstrado

${ }^{255}$ BRITO, F. Finalidade do mundo: estudos de filosofia e teleologia naturalista, Tomo II, p. 151. Disponível em: <http://www.senado.gov.br/publicacoes/conselho>. Acesso em: 10 jan. 2021.

${ }^{256}$ MERLEAU-PONTY, M. Signos, p. 139. 
em ordem geométrica e por meio do método dedutível - fosse capaz de garantir a total inteligibilidade desse Deus, assim como a inteligibilidade da ordem da natureza inteira, o que é o mesmo. Tal como argumenta Merleau-Ponty, Spinoza também estava "obcecado por preocupações e por algumas ilusões de seu tempo". Ele, assim como tantos outros de sua época, acreditava que a filosofia poderia ser uma alternativa possível para o fim de uma longa tradição de conflitos, injustiças, perseguições religiosas e instabilidades políticas. E o que Spinoza acreditou ter alcançado com sua Ética? Ele próprio esclarece, quando, em resposta a Albert Burgh - na Carta 76 de sua correspondência - explica: "Eu não pretendo ter encontrado a melhor filosofia, mas sei que tenho conhecimento da verdadeira. Vós me perguntareis como eu o sei. Eu responderei: da mesma maneira que vós sabeis que os três ângulos de um triângulo são iguais a dois retos." ${ }^{257}$ Isto é, a obsessão de Spinoza, sua preocupação ou mesmo sua ilusão, não era a busca pela "melhor filosofia", mas pela "verdadeira". E o que isso significa? Significa que Spinoza, assim como tantos outros de seu tempo, não apenas acreditava que o mundo é regido por leis certas e determinadas que podem garantir o conhecimento da verdade, como também acreditava que esse conhecimento é "possível” ao homem por meio do mesmo método utilizado pela matemática de sua época. Por isso a Ética é demonstrada em ordem geométrica e por isso, também, a integridade de seu método dedutível é capaz de garantir o "acesso" ao conhecimento da verdade acerca do conteúdo de suas proposições. Daí a importância do "método" para a leitura da obra.

No entanto, como diria Merleau-Ponty, a crença no método dedutível da ordem geométrica como garantia de conhecimento verdadeiro (ou conhecimento da verdade), era uma obsessão e, até certo ponto, uma ilusão que foi compartilhada por Spinoza e outros homens ilustres de seu tempo. A demonstração em ordem geométrica, tal como utilizada na Ética, não corresponde mais às expectativas e às obsessões do homem de nosso tempo. $\mathrm{O}$ homem da atualidade encontra-se rodeado por outras circunstâncias, inclusive pela incerteza da existência ou não da verdade absoluta, universal e logicamente dedutível, como acreditava Spinoza. É claro que isso não significa a supressão

${ }^{257}$ GUINSBURG, J.; CUNHA, N.; ROMANO, R. (Org.) Spinoza: obra completa II: correspondência completa e vida, p. 286. 
da crença na existência da verdade, muito pelo contrário. A verdade do conhecimento científico garantido pelo raciocínio lógico-dedutivo há muito se tornou uma realidade inquestionável, uma certeza que mantém viva a crença no predomínio da razão como um dos pilares da civilização humana. E é natural que seja assim, pois os ideais iluministas que nutrem essa obsessão nunca deixarão de existir enquanto durar a coerência das ideias que alimentam essa crença.

É nesse sentido que Merleau-Ponty afirma que um filósofo do passado se faz presente na atualidade. Ao responder aos "acasos" de seu tempo, como diz Merleau-Ponty, um filósofo do passado responde de tal maneira "que nos ensina a responder os nossos, embora estes sejam diferentes e diferente também a nossa resposta". ${ }^{258} \mathrm{O}$ filósofo do passado se faz presente através de suas ideias. Estas, se deslocam dos "acasos" de seu tempo para responderem aos "acasos" dos agentes de outras épocas, ainda que sejam por outros motivos e respondam a outras questões. Assim, entendemos porque o pensamento de Spinoza, ao longo de seus mais de três séculos de existência, continua nos ensinando as respostas aos "acasos" de nosso tempo, inclusive aos que foram apresentados por esta dissertação, ao longo de seus três capítulos, em que tentou explicar como Spinoza nos ensina o que é a natureza humana, a vida cognitiva e a vida afetiva.

E de que maneira Spinoza respondeu à obsessão desta dissertação? No primeiro capítulo, nos ensinando que a mente é "aquilo que segue necessariamente da essência de Deus", cuja natureza essencial é expressar a potência divina por meio dos atributos pensamento e extensão, o que nos permitiu descobrir que a potência da essência de um intelecto único é a causa da origem da diversidade de ideias dos pensamentos singulares. Também nos ensinou, nas investigações desenvolvidas no segundo capítulo da dissertação, que é a união da mente com seu corpo que consolida o modo humano de existência, pois, como vimos, no pensamento de Spinoza, o que primeiramente constitui o ser formal da mente humana, nada mais é do que a ideia de seu corpo existindo em ato, o que nos permitiu entender que a vida cognitiva acontece a partir da relação entre a mente com seu corpo. Por último, na investigação apresentada no terceiro capítulo, aprendemos com Spinoza que os afetos são

${ }^{258}$ MERLEAU-PONTY, M. Signos, p. 139. 
uma equivalência entre as potências de agir do corpo e da mente, assim como posteriormente aprendemos que nossa essência, como modo singular que somos, é um "esforço pelo qual nos esforçamos para perseverar na existência". Também aprendemos que os afetos de alegria, tristeza e desejo - chamados por Spinoza de afetos primários - são responsáveis, através das operações da imaginação, pela origem de todos os outros afetos da realidade de nossa vida afetiva.

Conforme foi destacado na introdução desta dissertação, além dos comentários de outros filósofos, vimos escritores e poetas prestarem homenagem a Spinoza em reconhecimento à grandiosidade das ideias de sua obra, sem falar no crescente interesse pela filosofia spinozista que frequentemente observamos nos estudos apresentados por inúmeros especialistas das mais diversas áreas do conhecimento. Tudo isso só reforça a teoria defendida por Merleau-Ponty de que as ideias do pensamento de Spinoza continuam tão presentes em nosso tempo, quanto estiveram em sua própria época. E esta dissertação, que inicialmente tinha como objetivo o firme propósito de apresentar a investigação de seu "recorte" da Ética procurando não interpretar Spinoza, mas apenas entendê-lo, chega ao fim de sua jornada sem saber ao certo se cumpriu ou não seu objetivo, mas tendo a certeza de que as ideias aqui apresentadas nada mais são senão a constatação de que o pensamento de Spinoza continua sendo tão inovador e atual, quanto o fora em sua época. 


\section{6 \\ Referências bibliográficas}

ARISTÓTELES. Ética a Nicômaco. Tradução Antônio de Castro. 2. ed. São Paulo: Forense, 2017.

BRITO, F. Finalidade do mundo: estudos de filosofia e teleologia naturalista. Tomo II. Brasília: Senado Federal, Conselho Editorial, 2012. Disponível em: <http://www.senado.gov.br/publicacoes/conselho>. Acesso em: 10 jan. 2021.

CHAUI, M. A nervura do real II: imanência e liberdade em Espinosa. São Paulo: Companhia das Letras, 2016.

- Desejo, paixão e ação na ética de Espinosa. São Paulo: Companhia das Letras, 2011.

DELEUZE, G. Espinosa e o problema da expressão. Tradução de GT Deleuze - 12; coordenação de Luiz B. L. Orlandi. São Paulo: Editora 34, 2017.

ESPINOZA, B. Ética: demostrada según el orden geométrico. Tradução, introdução e notas de Vidal Peña. Madri: Editora Nacional, 1980.

GUEROULT, M. Spinoza. vol. 1 (Dieu). Paris: Editions Montaigne, 1997 (Analyse et Raisons).

Spinoza II. L'âme. (Ethique, II). Paris: Editions Montaigne, 1974.

GUINSBURG, J.; CUNHA, N.; ROMANO, R. (Org.) Spinoza: obra completa II: correspondência completa e vida. São Paulo: Perspectiva, 2014.

JAQUET, C. A unidade do corpo e da mente: afetos, ações e paixões em Espinosa. Tradução Marcos Ferreira de Paula e Luís César Guimarães Oliva. Belo Horizonte: Autêntica Editora, 2011.

MACHEREY, P. Introduction à l'Ethique de Spinoza: la troisième partie, la vie affective. Paris: Presses Universitaires de France, 1995.

MARTINS, A. (Org.). O mais potente dos afetos: Spinoza \& Nietsche. Revisão técnica: Danilo Bilate. São Paulo: Editora WMF Martins Fontes, 2009. 
MERLEAU-PONTY, M. Signos. Tradução Maria Ermantina Galvão Gomes Pereira. Revisão da tradução Paulo Azevedo Neves da Silva. São Paulo: Livraria WMF Martins Fontes Editora, 1991.

REALE, G. História da filosofia 5: do romantismo ao empiriocriticismo. Tradução Ivo Storniolo. São Paulo: Editora Paulus, 2005.

SILVEIRA, N. da. Cartas a Spinoza. Rio de Janeiro: Livraria Francisco Alves Editora, 1995.

SPINOZA, B. de. Ética. Tradução Grupo de Estudos Espinosanos. São Paulo: Editora da Universidade de São Paulo, 2015.

Tratado da emenda do intelecto. Tradução e nota introdutória de Cristiano Novaes de Rezende. Campinas, SP: Editora da Unicamp, 2015.

Princípios da filosofia cartesiana e Pensamentos metafísicos. Tradução Homero Santiago, Luís César Guimarães Oliva. Belo Horizonte: Autêntica Editora, 2015.

. Breve tratado de Deus, do homem e do seu bem-estar. Prefácio Marilena Chaui; introdução Emanuel Angelo da Rocha Fragoso, Ericka Marie Itokazu; tradução e notas Emanuel Angelo da Rocha Fragoso, Luís César Guimarães Oliva. Belo Horizonte: Autêntica Editora, 2014.

- Tratado político. Tradução, introdução e notas Diogo Pires Aurélio; revisão da tradução Homero Santiago. São Paulo: WMF Martins Fontes, 2009.

Tratado teológico-político. Tradução, introdução e notas Diogo Pires Aurélio. Prefácio. São Paulo: Martins Fontes, 2003. 